A Teatralidade da Vida Cotidiana

$\oplus$

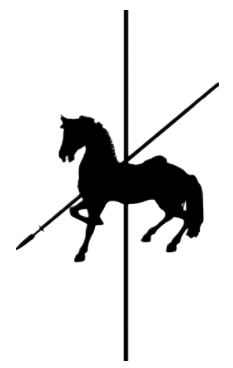


Autorizo a reprodução e divulgação total ou parcial deste trabalho, por qualquer meio convencional ou eletrônico, para fins de estudo e pesquisa, desde que citada a fonte.

Catalogação da Publicação

Escola de Comunicação e Artes da Universidade de São Paulo

Catalogação na Publicação

Serviço de Biblioteca e Documentação

Escola de Comunicações e Artes da Universidade de São Paulo

Junqueira, Flávia

A Teatralidade da Vida Cotidiana / Flávia Junqueira. - São Paulo: d.m.

Junqueira, 2014. 167 p. : il.

Dissertação (mestrado) -- Escola de Comunicações e Artes /

Universidade de São Paulo.

Orientador: Ramiro, Mario.

1. FicçãoXRealidade 2. Teatralidade 3. Infância

4. Fotografia 
UNIVERSIDADE DE SÃO PAULO

ESCOLA DE COMUNICAÇÃO E ARTES

PROGRAMA DE PÓS-GRADUAÇÃO EM ARTES VISUAIS

\section{A TEATRALIDADE DA VIDA COTIDIANA}

Flávia Junqueira

Dissertação apresentada ao Programa de Pós-Graduação em Artes Visuais da Escola de Comunicações e Artes da Universidade de São Paulo, como exigência para obtenção do Título de Mestre em Artes. Área de Concentração Poéticas Visuais, sob orientação do Prof. Dr. Mário Celso Ramiro de Andrade. 
Nome: JUNQUEIRA, Flávia

Título: A Teatralidade da Vida Cotidiana

Aprovado em:

Banca Examinadora:

Prof. Dr.:

Instituição:

Julgamento: Assinatura:

Prof. Dr.: Instituição:

Julgamento: Assinatura:

Prof. Dr.: Instituição:

Julgamento: Assinatura: 
PARA:

os amigos,

Mannuela Lacombe Pires

Natalia Lopes

João Bechara Ventura

e meus pais,

Marcos Smith Angulo

Vera Locks Junqueira

h 


\section{Agradecimentos:}

Dedico este espaço ao agradecimento daqueles que estive ram presentes no percurso de construção desta pesquisa, corroborando com meu exercício de fotografar e escrever. Em primeiro lugar ao meu orientador Mário Celso Ramiro de Andrade (PPGAV - USP) pela sua dedicação e pelas correspondências.

Ressalto, igualmente, o apoio da CAPES, a qual possibilitou o pleno desenvolvimento desta pesquisa através do auxílio de bolsa, como também ao Programa de Pós-Graduação em Artes Visuais da USP por possibilitar condições à elaboração da presente dissertação.

Agradeço também aos professores Ronaldo Entler e Agnaldo Farias, pelas discussões e ajudas para a formulação deste trabalho e especialmente aos amigos Marcelo Junqueira Angulo, Mariana Fernandes, Leto William, Milene Cara, Roberta Maran, Rodrigo Urbano e Marcello Girotti, pela paciência e pela partilha dos dias.

Por fim, agradeço aos amigos e profissionais Adriano Gonfianti, Lucas Albim, Lucas Länder e Maria Amália Bazuchi pela assistência na produção dos projetos plásticos aqui apresentados e na organização desta monografia. 


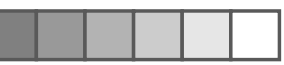

\section{Resumo:}

JUNQUEIRA, Flávia. A Teatralidade da Vida Cotidiana. 2014. 167 f. Tese (Mestrado) - Escola de Comunicação e Artes, Universidade de São Paulo , São Paulo, 2014.

Os trabalhos plásticos apresentados nesta dissertação foram desenvolvidos durante a pesquisa de mestrado em poéticas visuais e buscam refletir algumas possíveis relações entre o campo da vivência real (vinda de uma funcionalidade presente no cotidiano) e da vivência ficcional (vinda do universo alegórico da imaginação).

Nessas intersecções, sob a análise mais aprofundada do assunto "teatralidade da vida cotidiana", título que dá nome a dissertação, procuro evidenciar através de reflexões teóricas e construções estéticas, uma única noção de teatralidade que permeia a vida do homem e permite recriar a partir de alegorias do universo fantástico, diferentes maneiras de vivenciar a vida cotidiana.

Sob a luz de alguns preceitos teóricos e referências que permeiam os assuntos que dão continuidade a pesquisa plástica, desenvolvo através da apropriação de objetos, instalações e principalmente de encenações para a câmera fotográfica, alguns trabalhos que aqui serão apresentados e compõem a conclusão deste mestrado. 


\section{Abstract:}

"Theatrality of the quotidian life"

The plastic works presented in this essay were developed during a masters research in visual poetics and aim to reflect some of the possible relationships between the real living field - from a functionality found in quotidian - and the fictional living - from the allegorical universe of imagination.

In these intersections, under a deeper analysis of the subject "theatrality of the quotidian life", which titles this essay, I intend to expose through theoretical reflections and esthetic constructions a single notion of theatrality that pervades the human life and allows the recreation, from fantastic universe allegories, different manners of experiencing the quotidian life.

Under the light of a few theoretical rules and references that pervades subjects that give flow to the plastic research, I develop, through the appropriation of objects, installations and mostly photographic roleplaying, the works that will be presented here and that compose the conclusion of this master's degree. 


\section{Palavras Chave:}

\section{FICÇÃO X REALIDADE}

TEATRALIDADE: Teatro, ilusão, simulação, representação, imaginação, idealização, ação performática, encenação, cenário, ritual.

--lugar de tensão entre ficção e realidade.

INFÂNCIA: infantilização, sem fala, fantasia da infância. --lugar de tensão entre ficção e realidade.

FOTOGRAFIA: fotografia documentada, arquivo, catalogação, memória - fotografia encenada, visível e invisível, invenção. -- lugar de tensão entre ficção e realidade. 


\section{SUMÁRIO:}

2. Trabalhos plásticos realizados anteriormente aO Mestrado

4. A Teatralidade da Vida Cotidiana

4.1 Realidade X Ficção na Teatralidade

4.2 Teatralidade

4.3 Infância

4.4 Fotografia: Processo de Encenação e Documentação

5. Poética visual desenvolvida a partir do Conceito de Teatralidade

5.1 Apresentação da Poética Desenvolvida

5.2 Projeto para Finais Felizes

5.3 Mickey's Daily Work

5.4 Níveis

5.5 A Criança e sua Família 
“...Em nossa única dimensão grandiosa trazida pelo imaginário, posso inventar outros mundos, outras perspectivas. A imaginação me apresenta um outro "eu" no qual minha realidade temporária e desprezível se transforma. Nesse terreno sem limites, sem regra, em que posso estar no centro, a imortalidade não é uma esperança. Ela me pertence. Um enorme tesouro de possibilidades é colocado a disposição pelos sonhadores. Posso me tornar um rio, um furacão, um fantasma, a mulher invisível, posso também escapar de mim e me imaginar na pele dos outros, graças aos outros (...) Somos todos Potenkins, erguemos as pressas para a passagem da imperatriz fachadas brilhantes para dissimular, lá atrás, a essência do construído, do sólido. E a imperatriz, por sua vez, assim como todos os soberanos, finge acreditar. Escolhe permanecer cega ao estratagema, ordena que se ergam Palácios gloriosos para desviar os olhos da miséria perseverante do povo (...) Seja por ilusão, esquecimento, coragem, sacrifício ou imaginação, posso me tornar um outro, vestir outros personagens, lutar nos campos de batalha da ficção ou da realidade, posso criar modelos de mim, mas sempre carregarei comigo a fragilidade de minha natureza. Uma fragilidade que não pode estar mascarada, negada ou escondida por uma tentativa indestrutível e invencível. A solidez conhece suas fraquezas; a fragilidade as põe de lado."1

${ }^{1}$ Ana Lúcia Pardo. A teatralidade do Humano. pag. 42. Parte deste trecho é também uma citação do livro Fragilidade de Jean Claude Carriére pág. 14. 


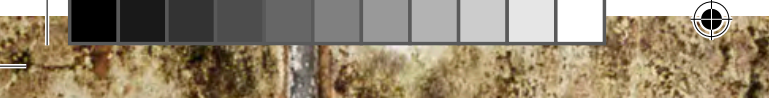

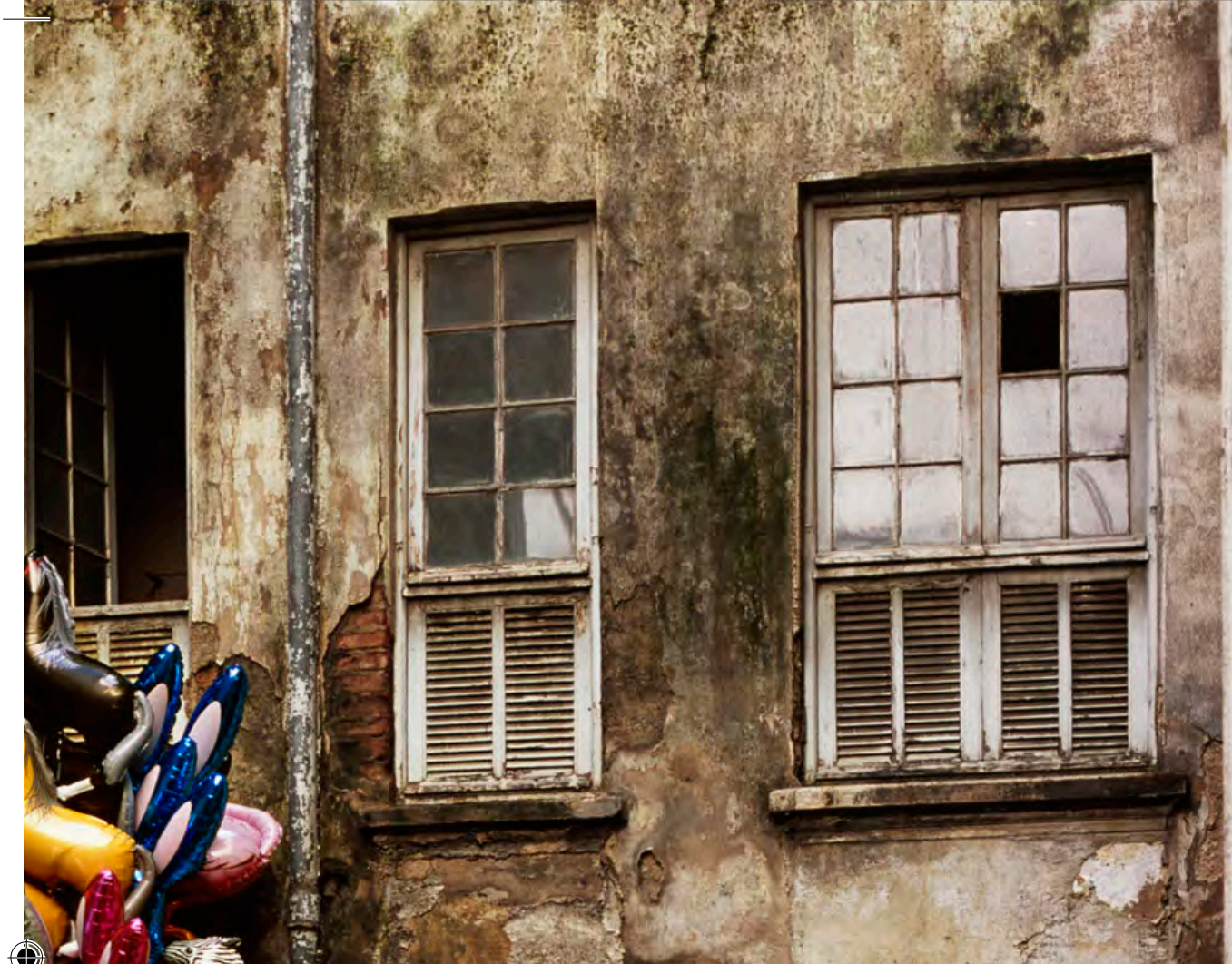

(4) $4 y^{2}=120$

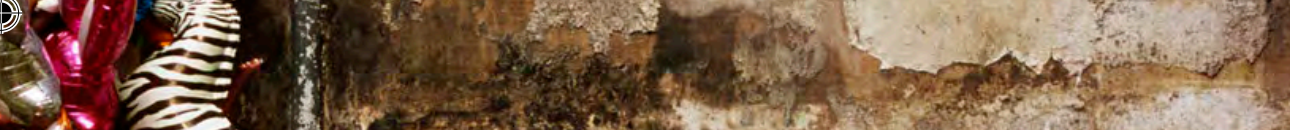

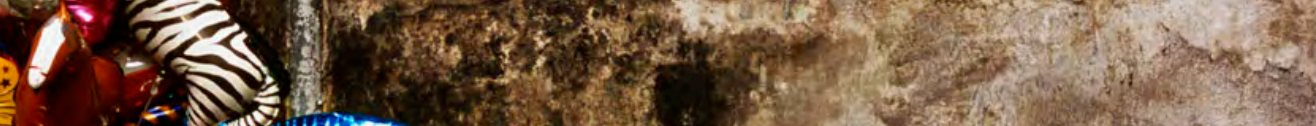

(4) $\int^{2}$

$8, \cdots \rightarrow$

$\rightarrow 7$

4

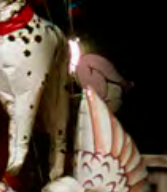

- -033

20.
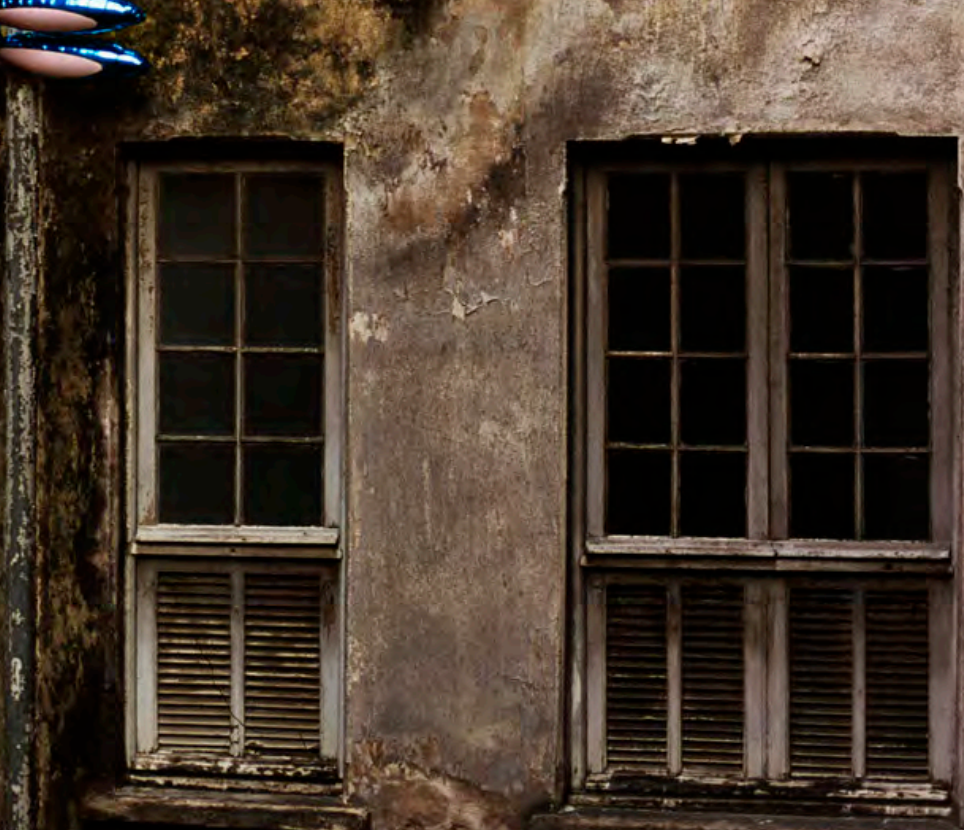
INTRODUÇÃO AO TEMA TEATRALIDADE

DA VIDA COTIDIANA.

$\oplus$ 


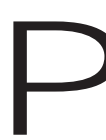

ensar no significado da idéia de Teatralidade a partir de uma perspectiva ampla, que supera o âmbito apenas teatral como encenação de espetáculo, e passa a ter uma presença significativa no cotidiano real dos indivíduos, é um dos principais assuntos que neste momento desejo discutir no meu trabalho de artes plásticas. Entretanto, para além de uma Teatralidade utilizada como representação funcional para manutenção da vida cotidiana ${ }^{2}$, procuro pensar em uma Teatralidade que se apresenta como meio de ficcionalização e distanciamento da realidade, o que chamarei particularmente de Teatralidade Extravagante 3 .

Desse modo, o que me interessa não são as representações que o indivíduo cria para se moldar à condições ditadas pela realidade, mas sim às representações em que se ficcionaliza através do universo imaginário fantasioso uma idealização do mundo real, tornando-o menos funcional e duro. Vale ressaltar que para este trabalho, os conceitos e imagens plásticas que discutem este tipo de Teatralidade são tensionados diretamente a um embate entre Realidade e Ficção e atuam lado a lado sobre um mesmo peso, criando intersecções que ora produzem estranhamentos e ora semelhanças.

O interesse em observar, analisar e através de minha pesquisa evidenciar alguns aspectos estéticos da "representação teatral" e dos "objetos fantasiosos" presentes como interferência na ação da vida cotidiana, surge de uma constatação e também obsessão particular e faz parte do processo de minhas descobertas como artista, principalmente com a câmera fotográfica. Por isso, é importante nesta introdução, sustentar e assumir um olhar particular meu, que impõe um sentido "árduo" para 0 entendimento da realidade e que trás o universo imaginário como meio de "fuga" ou "resposta" para este sentido. Vale dizer que o fato dessa Teatralidade a que chamo de Extrava

\footnotetext{
${ }^{2}$ Ervin Goffman, cientista social, em seu livro A Representação do Eu na Vida Cotidiana, trata da re presentação como meio de manutenção dos papéis que o indivíduo desempenha ao longo de sua vida. ${ }^{3}$ Extravagante adj. 1. Que se desvia da normalidade; excêntrico. Ref.: Minidicionário Luft.

4"EssênciadeVidro" éum conceito tratadopelo filósofo eroteiristaJean ClaudeCarriéreem seulivro Fragilidade ao sereferir a mortalidadeefragilidade quetodos os seres humanos carregam internamenteconsigo mesmos.
} 
gante, criar superfícies que amenizem a fragilidade da "essência de vidro" 3 da realidade que cada indivíduo carrega consigo mesmo, não os torna mais ingênuos ou infantis. De todo modo, o universo infantil e seus desdobramentos é explorado com muita recorrência nos trabalhos plásticos que desenvolvi para este mestrado, e isso acontece principalmente porque na minha opinião, a forma estética ficcional de mais fácil acesso se encontra na infância (a ver, por exemplo, as cores berrantes dos objetos das crianças e o desprendimento fantasioso presentes nas alegorias infantis). Já o universo adulto, se bem observado, mantém em sua representação uma manutenção funcional de papéis nos estágios sociais, e mesmo no seu campo extra cotidiano, é na grande maioria das vezes visualmente mais limitado e reprimido.

Mesmo assim, vale ressaltar que ainda que a grande maioria dos trabalhos seja sobre este tema, a idéia não é pensar em uma infantilização contida na encenação e sim refletir sobre um ideal quase gené rico que consiste em diferentes possibilidades de vivenciar de modo mais "ficcional" a realidade comum de nosso cotidiano. Mas, além dessas relações entre esses objetos de encenação vindos de um modo docemente imaginário e seu encontro com a solidez da realidade, existe também um outro ponto a pensar, pois nesse momento meu objetivo é criar visualmente uma proposição dedicada a apresentar dois momentos entre Realidade x Ficção; ora quando se apresentam em conflito e anulação e ora quando se somam. Em ambos os casos, são criados na reflexão um terceiro espaço ${ }^{5}$ de entendimento.

Na primeira situação, uma espécie de ruína surge como fruto deste atrito, pois noto que ainda que as tentativas Teatrais exponham sua presença sobre a vida, a realidade muitas vezes se sobrepõe e a satisfação plena da nossa imaginação pode ser interrompida.

${ }^{5} \mathrm{O}$ quechamoaquideterceiro espaçoliga-seaimagem fotográficaquemuitasvezespropõeumaconstrução cenográfica, quevalendo-sedo conflitorealidadexficção, geravisualmenteumnovolugar, desconhecidoemelancólico.

${ }^{6}$ Essas afirmações ficarão mais claras na medida em que apresentarei logo a frente um caminho entre meus trabalhos plásticos realizados anteriormente com a conclusão de minha graduação em 2008 e os anos seguintes, até a pesquisa atual que compõe esta dissertação de mestrado. 
Na segunda situação, os elementos ainda que opostos se somam, potencializando as diferenças de cada um, gerando novos entendimentos $^{6}$.

Desse modo, reafirmo que o objetivo de minha dissertação não é somente frisar a Teatralização da vida cotidiana, mas é também pensar em um intermédio entre o encontro de sobreposições que ocorrem dentro desses dois caminhos (Realidade x Ficção) e observar quais são os estranhamentos que surgem entre eles: melancolia, solidão, desapontamento, nostalgia, desconhecimento, ilusão, enfim, o que há defantasmagórico eque está contido no universo do imaginário são elementos importantes que surgem dessas ligações.

Esse encontro de tempos diferentes, de objetos representados e suas representações, de uma vivência mediada por encenações em que não sabemos de fato designar o que é verdadeiro do que é falso, são pontos que nos deixam apenas vestígios em que não sabemos bem como podemos nos firmar diante deles. Essa melancolia presente em um desapontamento de um "giro consecutivo ininterrupto que caminha em torno de si mesmo"7 e não chega a lugar nenhum é também o que desejo refletir.

A Fotografia como meio processual para a construção dessa pesquisa, se encaixa aqui perfeitamente, pois carrega em si uma técnica e forma que nos permite visualizar situações, propondo pensamentos que viajam além do quadro da imagem e nos dando poucas certezas do que de fato aconteceu ou não aconteceu. Na maioria das vezes, a finalização dos trabalhos plásticos aparecem através da construção de fotografias, encenações para a foto, instalações e apropriações de documentos ou objetos que giram em torno deste tema.

Para o tempo desta dissertação, creio que observar essas situações fantásticasmais "escancaradas" no cotidiano, sejam interessantespara desenvolver um ponto de vista a cerca do papel da Teatralização na vida cotidiana dos indivíduos. Por este motivo opto por privilegiar principalmentenapesquisaplásticaarelação entreFicção x Realidade.

${ }^{7}$ Esta frase faz referência a instalação intitulado "Estudo para Inversão" que apresento com mais detalhes no Cap. 5. A instalação é composta por um carrossel em escala real que gira no sentindo contrário. 
Ao pensar essa relação, escolho três pontos que se nivelam e se completam para firmar esta perspectiva: a Teatralidade da vida cotidiana, que dá nome a essa dissertação, como ponto de tensão entre Ficção e Realidade, a Infância como ponto de tensão entre Ficção e Realidade e a Fotografia, se bem entendida, também como ponto de tensão entre Ficção e Realidade.

São esses três assuntos chave que me proponho estudar neste mestrado, tomando como principal caminho metodológico, trazer a luz alguns dos meus trabalhos em artes que já foram realizados anteriormente e que são muito importantes para fundamentar as descobertas, conceitos e processos dos assuntos apresentados como parte da pesquisa teórica e plástica dos trabalhos atuais. Afinal, pensar sobre o tema da Teatralidade, não é um assunto que surge como escolha aleatória, mas sim como algo que já se apresentava como questão desde os meus primeiros projetos há 4 anos atrás, porém de modo mais obscuro e tímido.

Desse modo, passo a passo, paralelamente as reflexões que obtive através das discussões com meu orientador e as disciplinas escolhidas durante a pós-graduação, apresento nessa dissertação minha atual pesquisa em artes, acompanhada de minhas descobertas teóricas e práticas. Porém, é importante antes de mais nada, para entender como cheguei aqui, percorrer e compreender um pouco do que eu vinha propondo nos meus trabalhos anteriores ao mestrado. Isso é o que farei no capítulo a seguir. 
TRABALHOS PLÁSTICOS REALIZADOS

ANTERIORMENTE AO MESTRADO.

(†) 


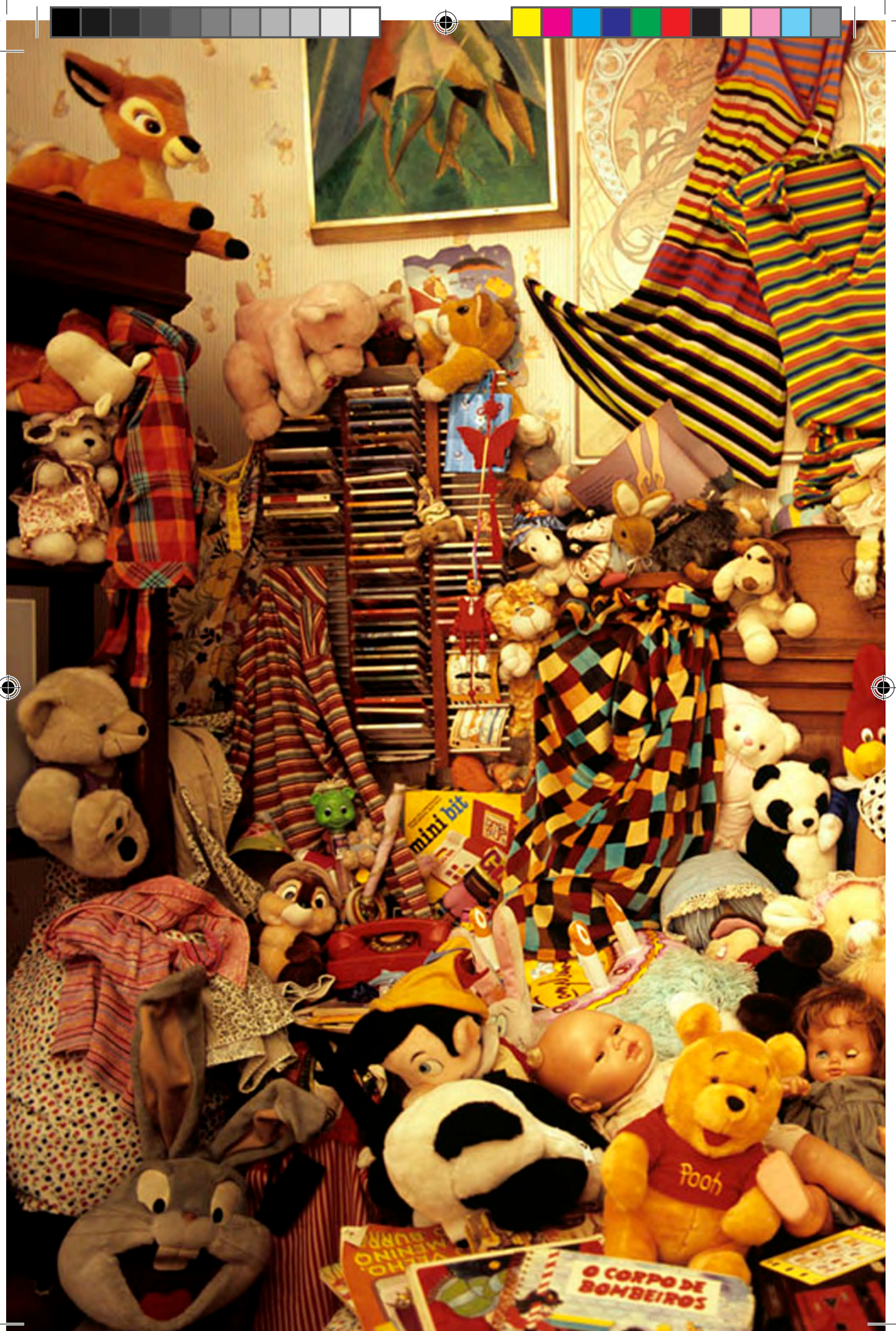




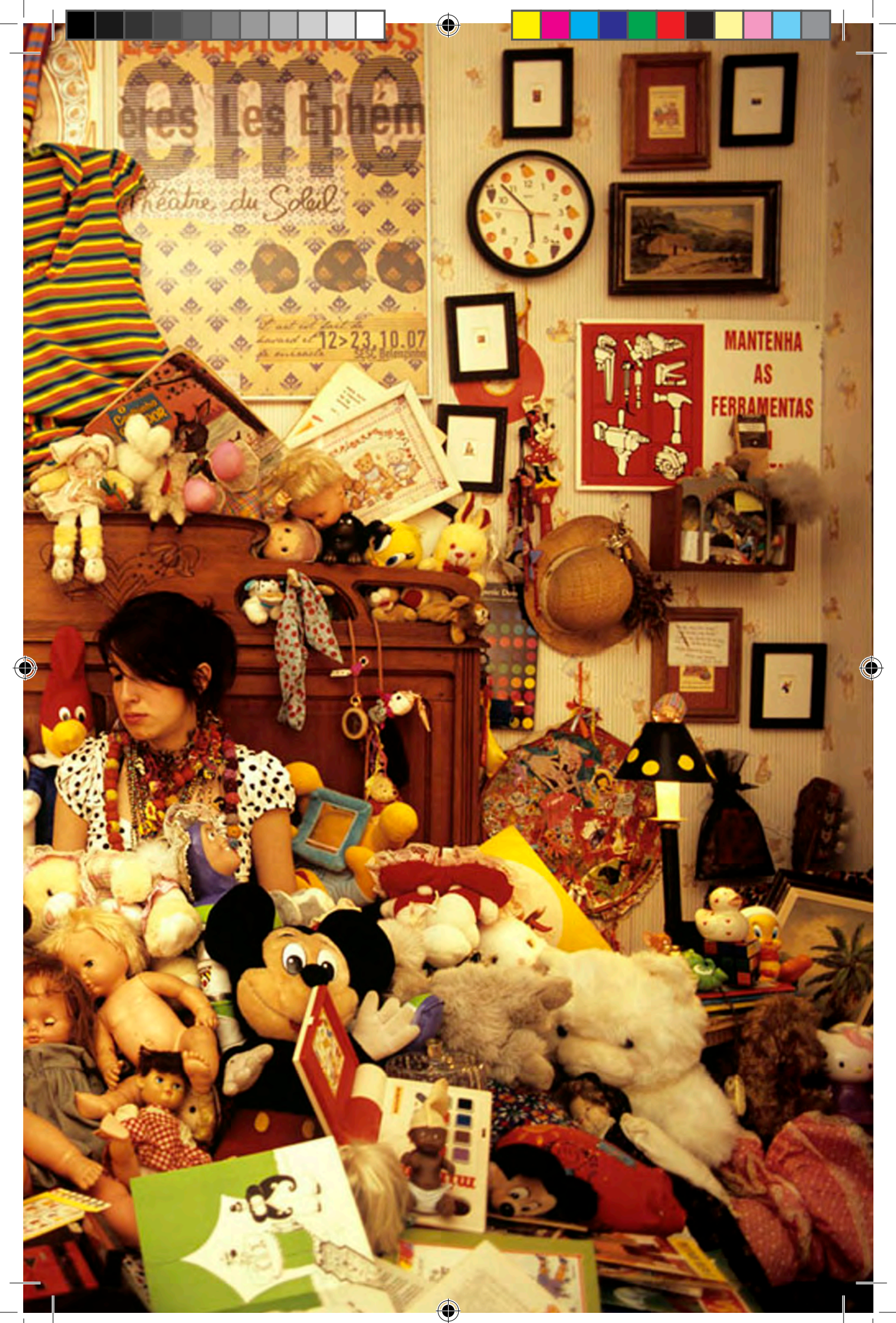




\subsection{A FANTASIA SOBRE SI MESMO}

D ara falar sobre o tema da Teatralidade presente na vida cotidiana, a que proponho as reflexões desta dissertação, acredito que seja necessário primeiro percorrer um caminho sobre os meus trabalhos anteriores (realizados desde minha conclusão na Graduação em 2008 até agora). Isso porque, na minha opinião, é importante analisar os percursos traçados levando em consideração um olhar atento sobre todos os aspectos que as primeiras produções apresentaram.

Pensar sobre o passado é um modo de enxergar com mais clareza algumas inquietações que são tratadas atualmente nesta pesquisa e que certamente brotaram de um momento anterior. Meu objetivo neste mestrado não é criar grandes conceitos para elucidar meu trabalho plástico, mas ao contrário, desejo deixar a apresentação de minha produção (passada ou presente) guiar a teoria, possibilitando uma construção que dialoga de modo a igualar obra e conceito numa dimensão simultânea, sem grandes pretensões em definições teóricas ou filosóficas.

Como disse, durante a graduação em Artes Plásticas, realizei alguns trabalhos que foram importantes para afirmar o meu posicionamento diante do tema que apresento aqui. Assim, os primeiros trabalhos que escolhi para relembrar são os que aconteceram dentro de um âmbito bastante íntimo, a pensar uma idéia plástica a partir da apropriação de objetos da casa como espaço cênico para a construção das fotografias.

O título que denomino este primeiro momento de minha produção, é A Fantasia sobre si mesmo, pois a maioria dos primeiros trabalhos aconteceram dentro de uma relação processual fechada, em que eu me reconhecia como artista de modo biográfico, au- 
to-analítico e pessoal; buscando construir uma fantasia sobre mim cercada de objetos e histórias de minha própria vida. Vale dizer que as imagens, ainda que cenografadas, apresentavam um grande leque documental, pois eram constituídas de objetos que faziam parte de uma história pessoal.

O primeiro trabalho que creio ser importante para delinear algumas questões atuais, aconteceu em 2007 durante meu curso de graduação na faculdade de Artes Plásticas da FAAP, onde realizei um projeto de fotografias em pequeno formato intitulado Retrato 3x4 (Imagem-Anexa I). Este trabalho se caracterizava por uma instalação composta por 100 pequenos "quadrinhos" que abrigavam dentro de si, imagens de objetos fotografados em formato de retratos de identificação $3 x 4$.

Os pequenos quadros foram emoldurados com uma madeira escura e barroca com o intuito de forçar uma estética que reportava algo tradicionalmente vindo de uma memória imaculada, como se cada retrato fosse completamente único. Esses retratos eram imagens de objetos pessoais de alguns amigos e a idéia era coletar e obter uma coleção de objetos biográficos ${ }^{8}$ que formariam juntos uma pequena coleção de memórias, onde cada possuidor de sua re líquia pessoal pudesse apresentar seu objeto "idealizado" de apego.

Já no final de 2008 para 2009, dando continuidade aos trabalhos plásticos, eu ampliei a perspectiva da observação do objeto íntimo de pessoas externas a mim e comecei a refletir sobre encontrar objetos no meu próprio universo pessoal, isso aconteceu quando realizei auto-retratos e trabalhos auto-biográficos. Neste momento, fotografei os espaços íntimos da casa de minha família, onde na época eu ainda morava, e esses lugares passaram a ser registrados como uma espécie de "cenário" acumulado de objetos e documentos de minha memória.

\footnotetext{
${ }^{8}$ Segundo Ecléa Bosi no livro O Tempo Vivo Da Memória (ensaio de psicanálise social), os objetos biográficos são aqueles que envelhecem com o possuidor e se encorparam a sua vida: o relógio da família, 0 album de fotografias, a medalha do esportista, a máscara do etnólogo, etc.

9 "Quartos" (Rochelle Costi) - São Paulo / Rooms - São Paulo, XXIV Bienal de São Paulo, 1998.
} 
Os espaços, por sua vez, se tornavam um novo plano arquitetônico, pois perdiam suas características reais de uma casa comum e se transformavam uma casa fantástica, repleta de empilhamentos de cores e objetos.

Neste momento foi fundamental olhar para a influência do trabalho intitulado "Quartos"9 (Imagem-Anexa II) da artista plástica gaúcha Rochelle Costi, em que fotografias de grande escala mostravam o espaço físico de quartos de diferentes pessoas. Apenas os objetos do quarto desempenhavam o papel de caracterizar 0 que poderia ser 0 "perfil" de seus donos, pois nas imagens nós não podíamos ver as pessoas que habitavam estes quartos e sim apenas seus objetos no espaço íntimo do sono. Esses locais tornavam-se também uma espécie de cenário para a fotografia, apesar de serem principalmente uma fotografia de documentação.

Por conseqüência aos estudos e pesquisas, apresentei como conclusão de meu Trabalho de Graduação Interdisciplinar, uma série de fotografias que se chamava "Na Companhia Dos Objetos" (Imagem-Anexa III) Esta série era composta por oito imagens fotográficas em grande formato que apresentavam auto-retratos meus encenados para a câmera fotográfica. Durante este trabalho, eu me fotografei junto a todos os objetos que caracterizavam os diferentes espaços de minha casa e aparecia completamente acumulada em meio ao excessos de objetos e apegos que eram designados a partir da qualidade de cada espaço. No entanto, meu rosto se encontrava melancólico, indiferente e com um olhar vazio, como se ainda que em meio a todo aquele excesso de objetos e eu estivesse sozinha.

Em todas as fotografias era possível notar uma imagem completamente construída e cenografada, repleta de objetos vindos de um espaço determinado de dentro de uma única casa que se tornava "misteriosa", mágica e irreal. A junção de objetos reais de um cotidiano da casa, porém empilhados excessivamente de modo incomum, trazia para 0 trabalho um estranhamento que fugia a foto meramente documental, pois ainda que fiéis aos objetos pertencentes em sua realidade espacial, a imagem se tornava bastante 
ficcional.

Hoje, pensar nestes dois primeiros trabalhos é notar a forte ligação que minha pesquisa estabeleceu naquele momento em relação aos aspectos sobre o tema Ficção x Realidade e principalmente pensar como as primeiras fotografias já apresentavam tentativas de Teatralizar a vida cotidiana, fosse através da necessidade de transformar um objeto pessoal querido em uma relíquia de memória ou através da possibilidade de transformar a arquitetura de uma casa comum em um cenário pictórico e fantasioso.

Desse modo, a presença dos objetos diante de um sujeito que os possui, a memória que cada objeto carrega em si, o papel forte que ele desempenha como modo de completar o ser humano, a coleção, a catalogação, o apego, o acúmulo dos objetos, o espaço ficcional criado a partir da fotografia construída e a apropriação de elementos da realidade e da ficção, entre outros diversos pontos, estavam presentes neste trabalho como embriões que ao longo dos anos de estudo foram brotando e hoje servem como suporte para gerar uma continuação mais clara dessas reflexões.
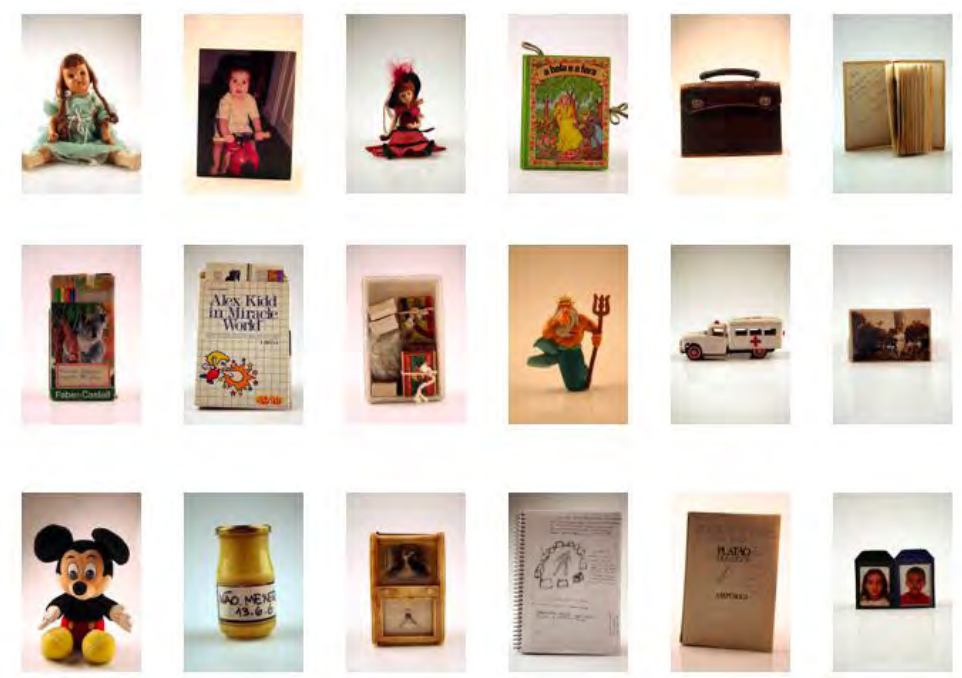

Anexo I: Retrato 3x4, 100 ampliações fotográficas em formato 3x4, 2007 

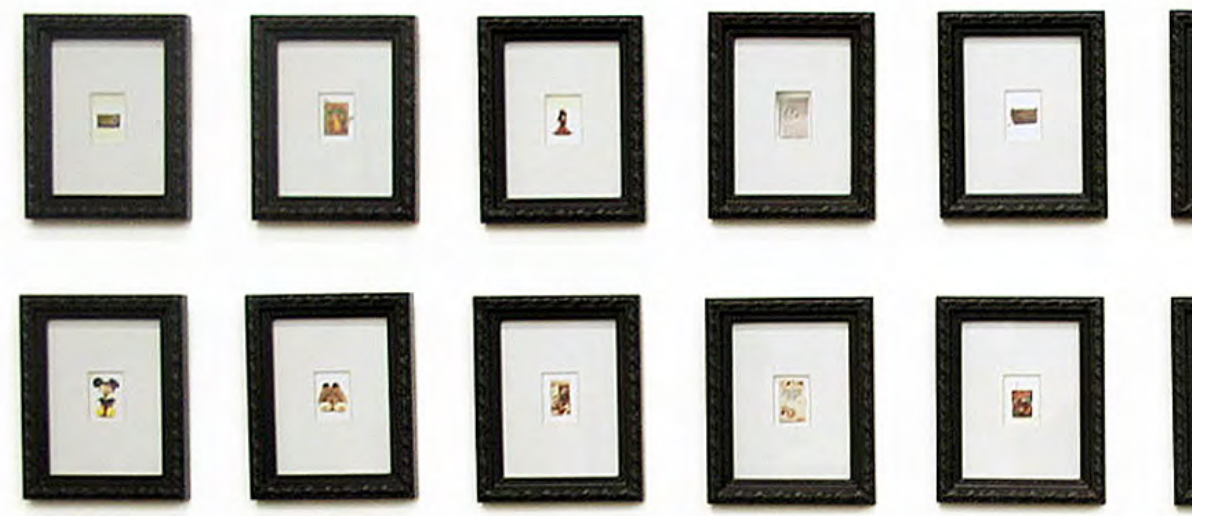

$\oplus$
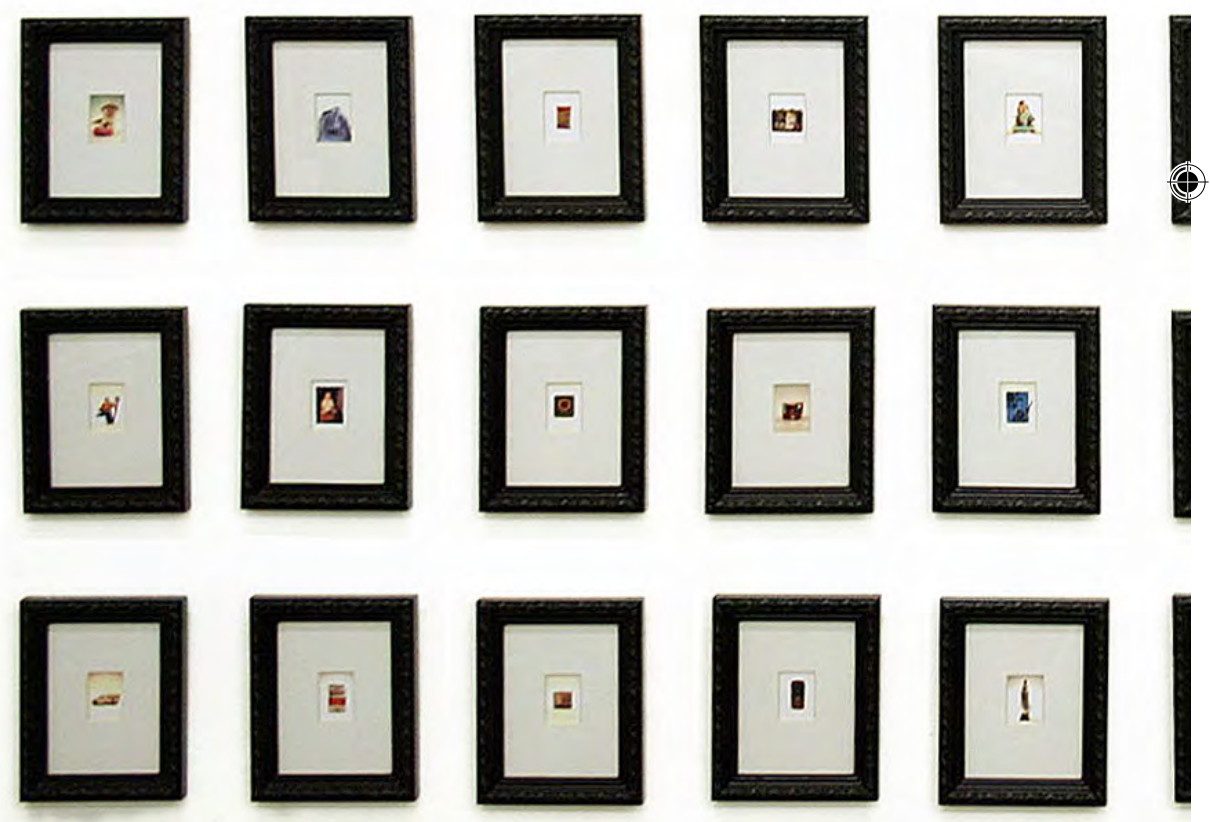

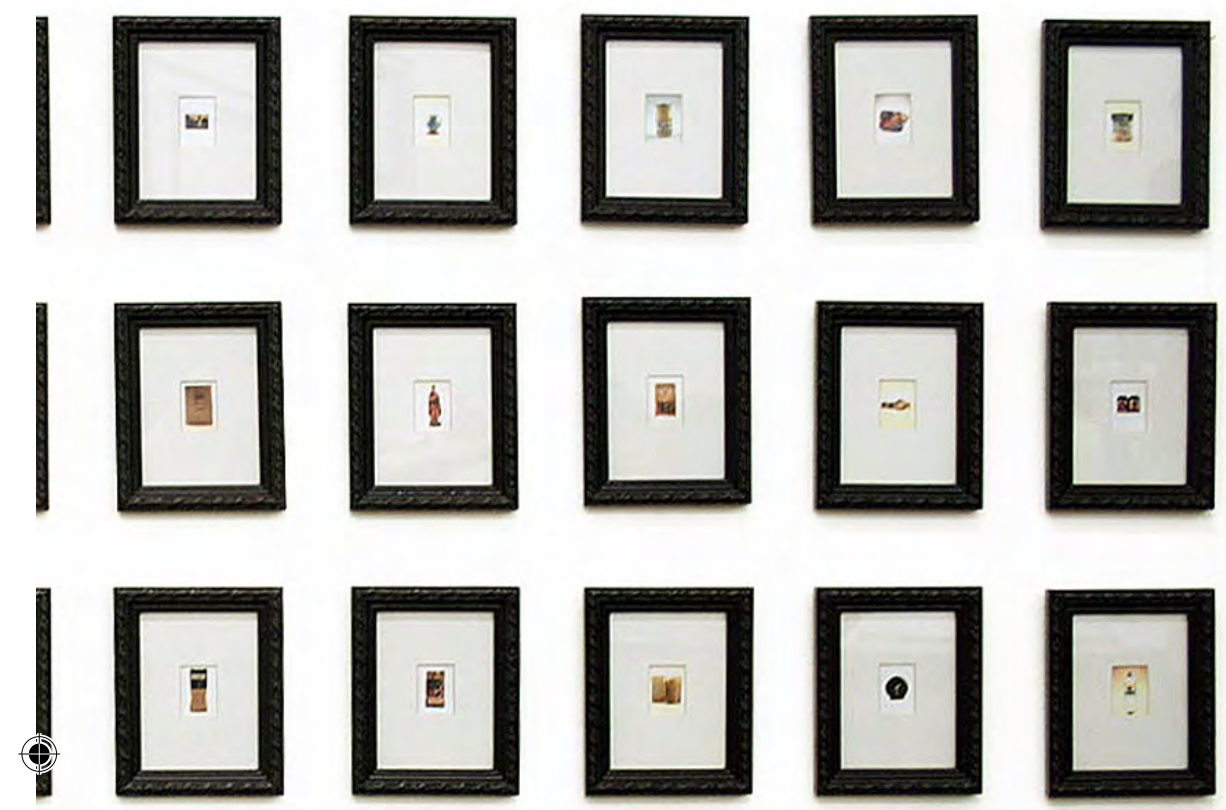

$\oplus$
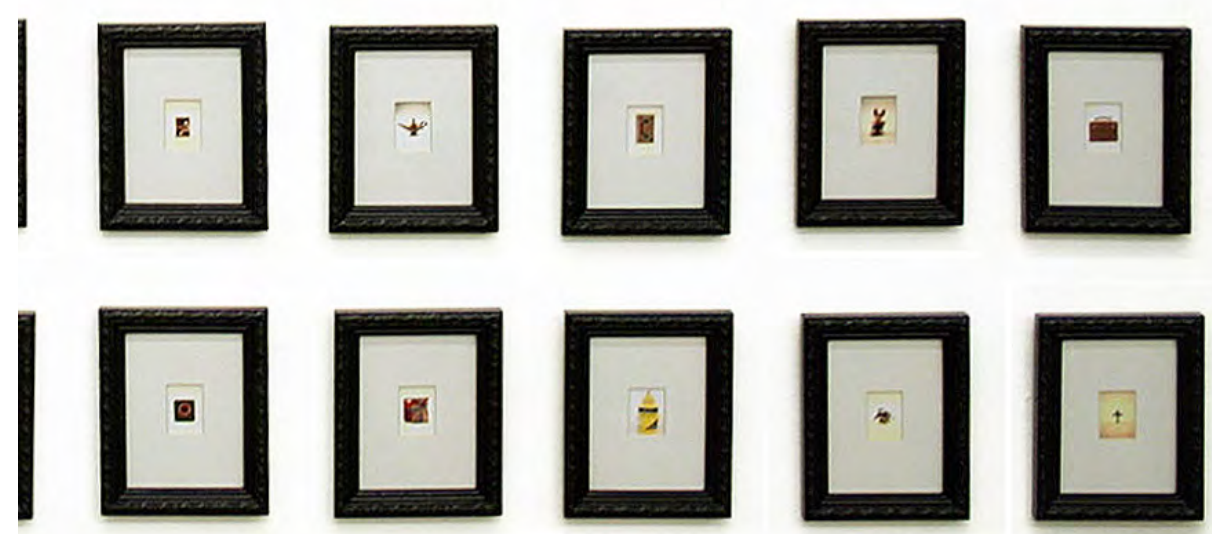


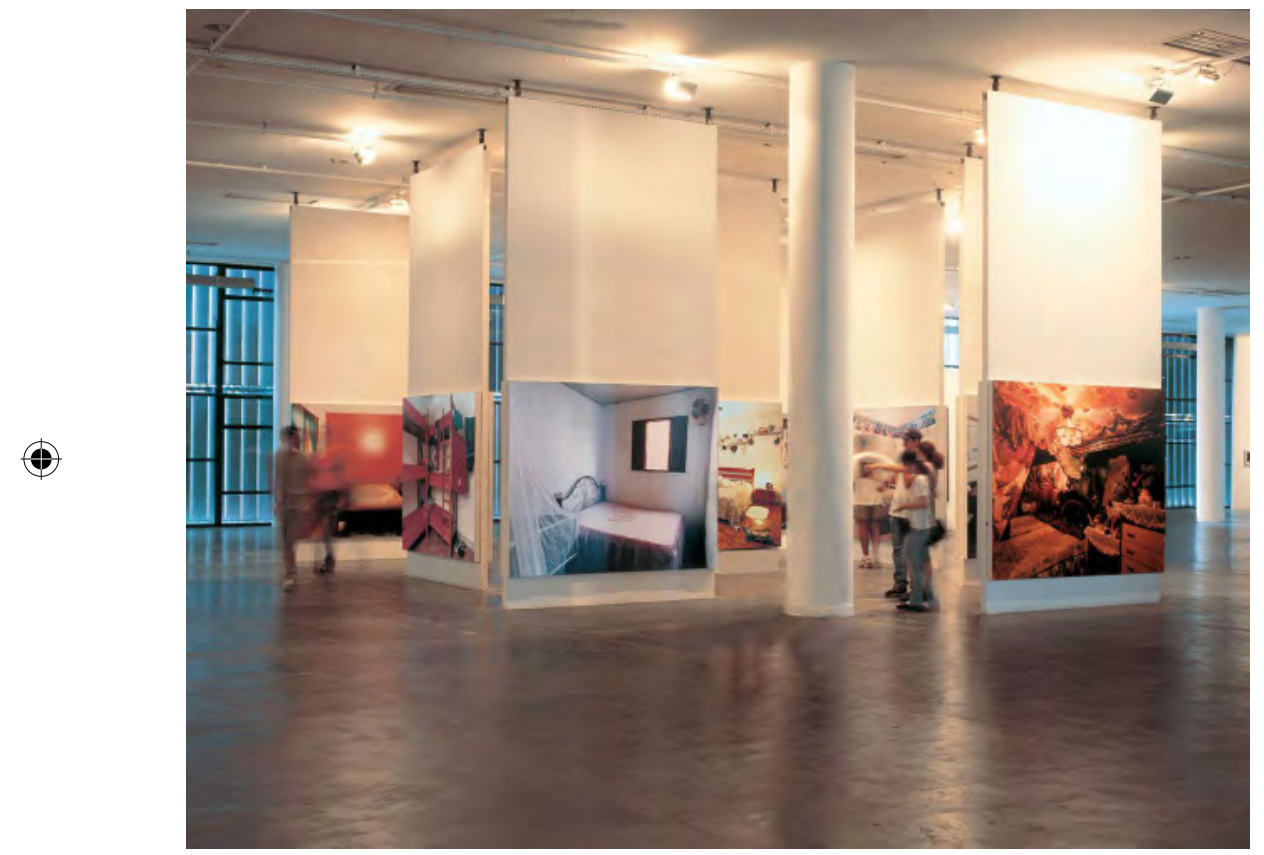




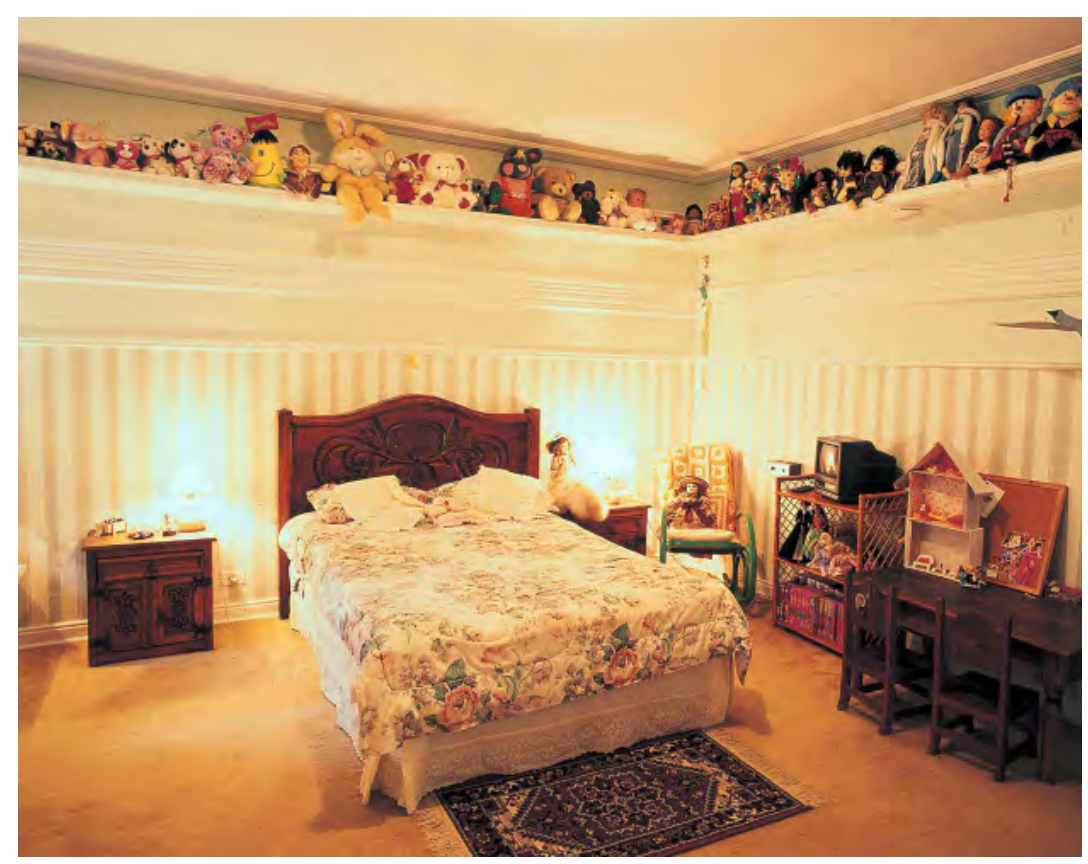




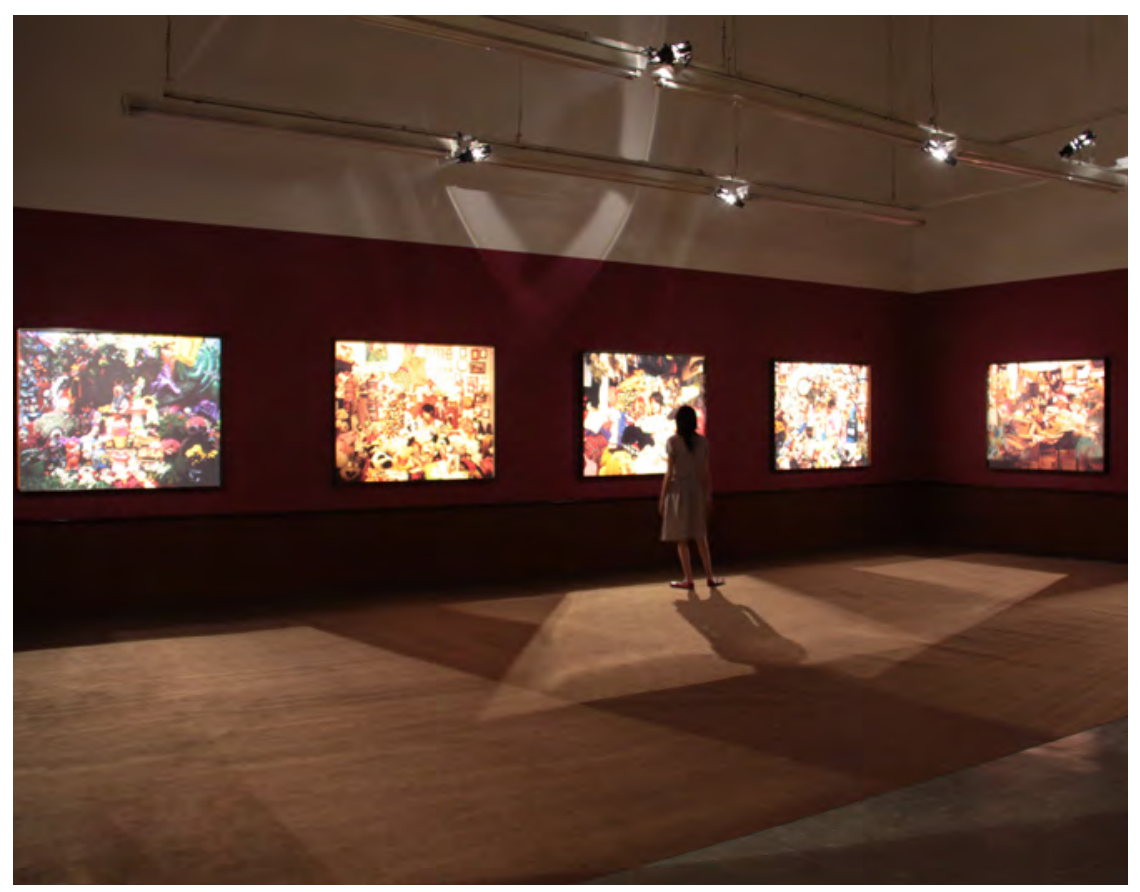




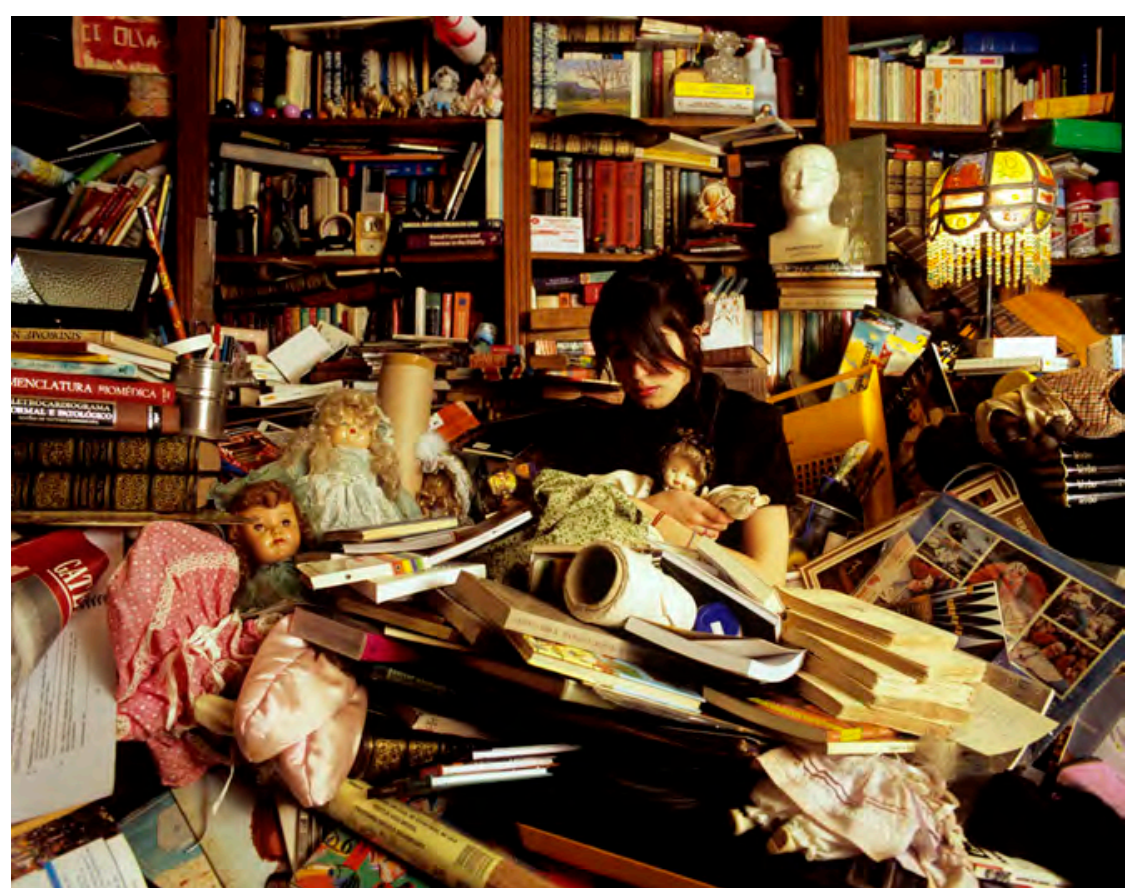


Já no ano de 2010 eu mantive a mesma linha de pesquisa e fui fiel a minha necessidade de construir fotografias encenadas em grandes escala, porém foquei em um tema específico que era explorar os objetos das festas do universo infantil. Vale lembrar que o elemento Infância começa a aparecer com mais força nesta nova série que passei a chamar de "A Casa em Festa". Com este foco, eu consegui assumir melhor a pesquisa de cenário, montagem, decoração, adereçamento, excessos e acúmulos, que já eram assuntos que apareciam na série "Na Companhia dos Objetos", porém ainda não exatamente intencionais.

Com esta segunda série consegui entender, que para além de tomar uma posição, por exemplo a criticar o excesso de objetos em contraposição a uma aparente solidão (como eu frisava conceitualmente na série "Na Companhia dos Objetos"), ou ao mesmo tempo defendêlos, o trabalho transitava exatamente ENTRE essas duas situações. 0 que 0 tornava mais curioso era essa ampliação de possíveis relações entre Realidade e Ficção, que permitiam apontar alguns sentimentos que não necessariamente eram objetivos e taxativos como na série anterior.

Para esta série (Imagem-Anexa IV), as fotografias eram novamente construídas através de cenas e compunham-se através de objetos e cenários mais "falsos". Assim como a série anterior, 0 trabalho "A Casa em Festa" também era fortemente cenografado e apresentava uma noção ficcional, mas neste caso, os elementos de festas pareciam tornar-se um "sobre-cenário", e a casa real recebia sobre si uma nova montagem temporal para a passagem de um ritual como o aniversário. Outro ponto que criava uma divergência entre essas duas séries, era a idéia de que com o tema das festas eu tentava criar um enjoamento/ estranhamento através do excesso de cores fortes e objetos decorativos artificiais.

Diferente da série "Na Companhia dos Objetos", é importante lembrar que em "A Casa em Festa" passei a criar uma nova estratégia para evidenciar a solidão e o desapontamento que antes apenas apareciam através de meu próprio rosto apático. Nestas 
imagens aspectos de abandono e decadência estavam presentes com intencional ironia na escolha dos objetos que compunham a cena: através de um detalhe de papel de parede rasgado, balões negros, confetes amassados, presentes rasgados ou "mascotes" de fantasias infantis fantasmagóricos e desanimados.

Estas eram maneiras que eu encontrava para tentar relacionar o tema da ficção e idealização presente nos objetos dos rituais da infância à uma certa melancolia e estranhamento impostos pela passagem do tempo de nossa vida real. Assuntos estes, que como apresentei nesta introdução, hoje estão fortemente relacionados ao modo pelo qual tenho processado com minhas novas pesquisas, inclusive afirmando a idéia da fotografia encenada, do terceiro espaço criado através da relação entre fantasia e realidade e principalmente a recorrência do tema da infância, memória e fragilidade.

Um quarto trabalho (Imagem-Anexa V), ainda desta série "A Casa em Festa \#6", apresentava uma imagem em que eu, como personagem, já não estava mais presente na fotografia, pois havia somente uma sala repleta de balões. Na imagem era possível reconhecer elementos da memória de uma sala de família comum, mas no entanto, o sentimento de desconhecimento através do acúmulo de balões em uma casa sem personagens e sem uma aparente movimentação de festa, propunha algumas estranhezas.

Assim como o termo "Heimlich" tratado por Freud em sua obra, que remete a idéia de que essa mesma palavra tem significados que coicidam com seu oposto, a minha idéia ao propor a imagem era causar uma espécie de estranhamento e familiriadade que fossem simultâneas. O pensamento que trazia para perto da memória um reconhecimento íntimo da casa e da sala de família, era ao mesmo tempo, o espaço arquitetônico que a repelia, com vazios e silêncios, tornando-a assustadora e melancólica.

E importante lembrar que no texto "Das Heimliche"10, Freud procura delimitar os vários significados que a palavra "heimlich" adquire no alemão, entre os quais está familiar, íntimo, lugar livre da influência de fantasmas, algo oculto e perigoso, afas- 
tado do conhecimento, assustador. Freud propõe que "heimlich é uma palavra cujo significado se desenvolve na direção da ambivalência, até coincidir com seu oposto "unheimlich". Freud então apresenta o significado de estranhamente familiar como sendo o "unheimlich".

Essa idéia, que surge em 2010, é mais um ponto que detenho atenção ao pensar minha necessidade de conceitualizar a Teatralidade da vida e seu embate com o que é Cotidiano, pois quando plasticamente invisto em apropriações que geram confronto entre Realidade e Ficção, proponho somas e subtrações que produzem por si só, um terceiro espaço, bastante familiar e bastante estranho.

${ }^{10}$ Freud, Sigmund,1856-1939. História de uma Neurose Infantil. O Inquietante, pag. 329. São Paulo-Companhia das Letras, 2010. 


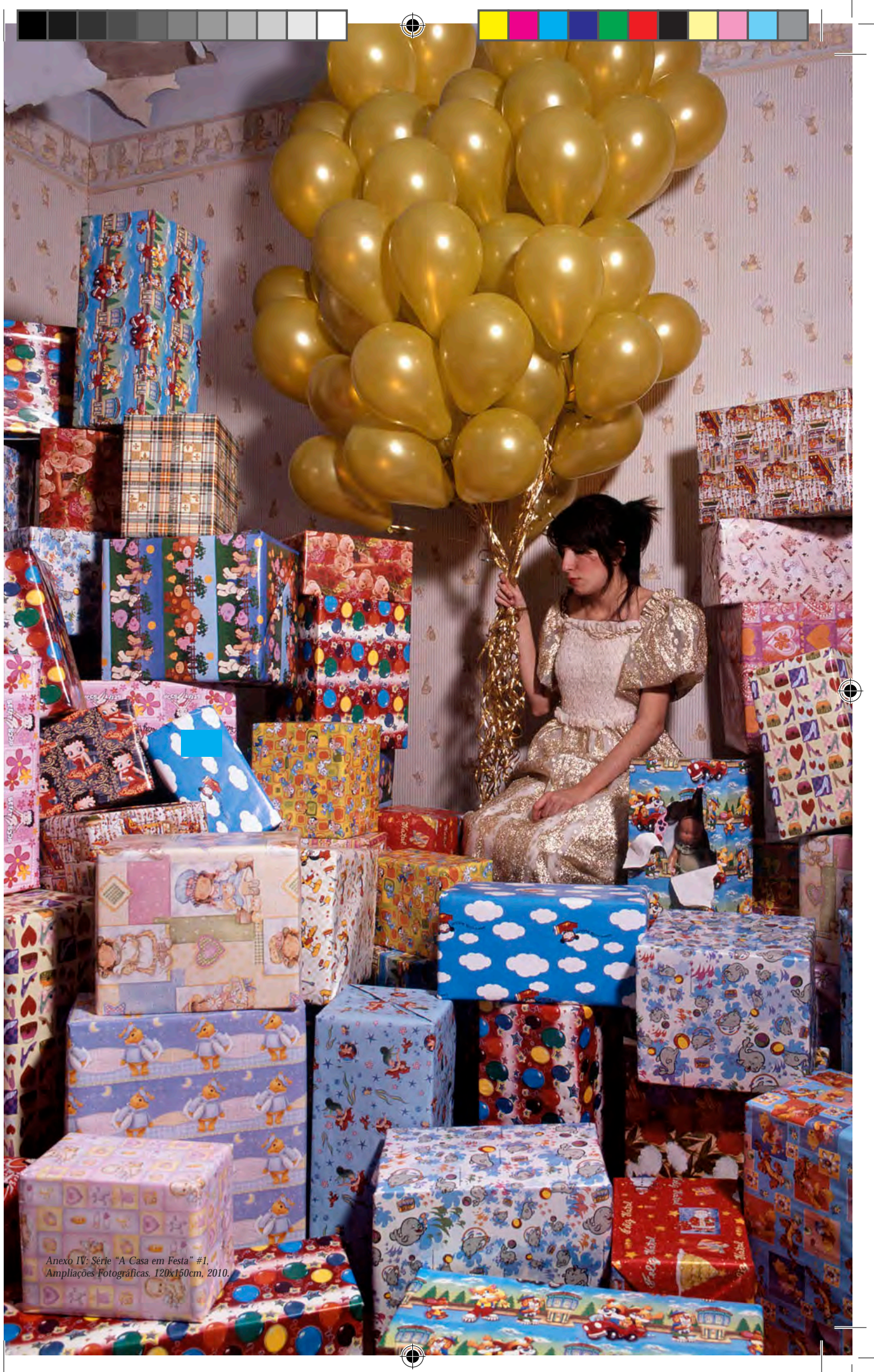




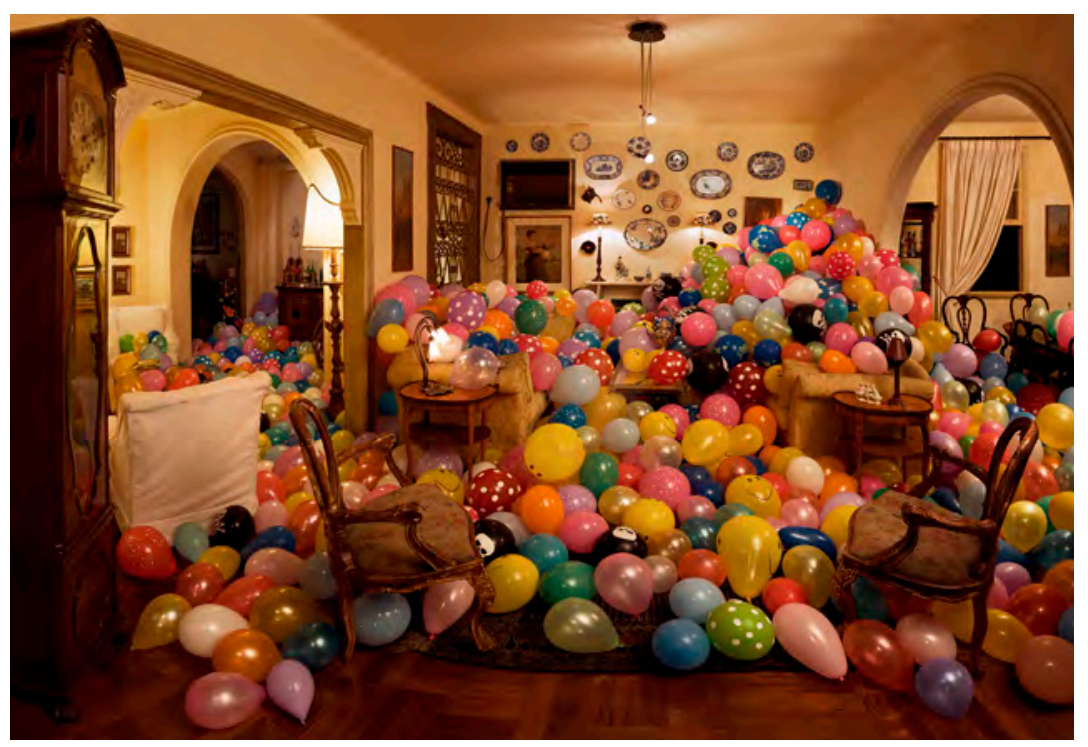




\subsection{A Fantasia DE SI COM OUTRO}

\section{$\mathrm{N}$} o final de 2010 tive a oportunidade de participar de uma residência artística localizada no centro histórico de São Paulo, onde fui inserida em um novo contexto para criar meu trabalho: eu não produzia mais dentro do ambiente seguro e íntimo da casa familiar, e ao contrário do que me era dado como de costume, me deparei com um espaço externo totalmente dife rente do meu.

É muito importante frisar este momento na construção do mestrado, pois foi através da participação desta residência, que eu me deparei com um novo modo de pensar algumas idéias que vinham sendo repetidas desde 2008. 0 que me fez, através da mudança de recursos, permitir com que o trabalho plástico ganhasse alguns saltos conceituais, que talvez não teriam sido realizados ausentes desta ocasião.

Desse modo, fui inserida em um estatuto de montagem de trabalho que não demandava unicamente de meu universo pessoal de memória auto-biográfica, e que ao residir em um espaço desconhecido, possibilitou uma união entre a pesquisa de um universo íntimo que já vinha sido explorada, com um novo espaço encontrado: o que me leva a denominar este período de trabalhos como A Fantasia de si com o outro.

Durante esta residência, realizei uma nova série de fotografias intituladas "Sonhar com uma Casa na Casa" (Imagem-Anexa VI), em que pedaços fragmentados de uma casinha de boneca colorida se misturavam a diferentes salas antigas, destruídas e cheia de memórias. A idéia de relacionar o universo idealizado infantil com seus objetos mágicos e artificiais e inserí-los em espaços de salas em escala real de um prédio antigo abandonado pela realidade 
do tempo, evidenciava a dicotomia e o embate óbvio da relação Realidade x Ficção.

O que era feito nas séries anteriores de modo bastante intuitivo, passava a ser neste trabalho totalmente intencional, porém a maneira pela qual eu criava a estratégia para demonstrar esses pontos, ainda eram muito simplistas e maniqueístas, no sentido de expor uma contradição muito evidente nas partes constituintes que geravam a imagem da fotografia. Vale ressaltar também, que 0 modo de operar na construção da cena para a fotografia era ainda bastante semelhante aos trabalhos anteriores, com a diferença que neste caso havia a saída do espaço íntimo de minha casa e a entrada de novos espaços que já apresentavam outras memórias interferidas pelos objetos que eu recriava. Essa intervenção do Belo x Sinistro ${ }^{11}$ era um novo início para pensar como a realidade e a ficção se entrelaçavam a todo momento nas fotografias encenadas.

Uma das intenções para além de propor um embate óbvio entre os objetos que representavam o "novo x velho" e "artificial $\mathrm{x}$ real", era também deixar evidente a imagem que se criava a partir da união desses dois polos. Ou seja, ainda que fosse possível notar elementos opostos em uma mesma cena, a relação era transformadora e deixava a imagem um pouco mais irreal e confusa. A quem olhasse a fotografia, era impossível descobrir se aquele cenário havia sido encontrado, interferido ou encontrado e interferido por mim.

De fato, o que foi feito ou não como recurso de construção da imagem, não me importava, no sentido de que a idéia era justamente propor essa confusão e estranhamento. Para além disso, era interessante ver que a imagem por si só não estabelecia uma unidade de entendimento e isso era importante, na medida que com 0 tempo, dissolvia a obviedade da relação primeira do trabalho, que apresentava uma estrutura de dois lados muito claros.

\footnotetext{
${ }^{11} \mathrm{O}$ conceito de Belo x Sinistro, é um termo explorado pelo teórico Eugênio Trias, ao discutir sobre a relação simultânea que existe entre a Beleza, estranheza e feiúra.
} 
Ainda em 2011, realizei uma série de trabalhos chamada "Gorlovka, 1951" (Imagem-Anexa VII). Essas imagens foram realizadas em um Palácio da Cultura da era soviética durante uma residência para fotógrafos no interior da Ucrânia. $\mathrm{O}$ projeto, que foi realizado para um lugar específico, tentava refletir um sentimento paradoxal que acompanhava a passagem do tempo. Uma ingenuidade presente nas imagens andava lado a lado com um senso de tragédia, onde a inocência infantil era justaposta com um senso de solidão e isolamento. Nas diferentes salas do Palácio eu encontrava objetos e marcas deixados pelo abandono

da história daquele local que não estava mais em funcionamento, mas

em contrapartida, trazia objetos novos que eram escolhidos através de meu universo pessoal. Eu os levava para dentro da arquitetura encontrada com 0 intuito de fazer 0 exercício de observar os distanciamentos e proximidades dessa união.

Seguindo o objetivo de dar seqüência a uma vontade de explorar espaços obscuros e carregados de história e re-contextualizá-los através da inserção de objetos cênicos deslocados, assim como na série "Sonhar com uma Casa na Casa”, eu tentava criar novamente uma ficção a partir da sobre posição de elementos inventados. Mais do que somente observar, registrar e documentar situações ficcionais, eu tentava construí-las através de um imaginário nem totalmente fictício e nem totalmente real.

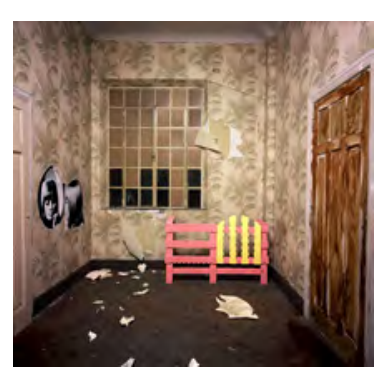

Anexo VI: "Sonhar com uma Casa na Casa", Ampliação fotográfica, 2011.
Realizada durante a residência RedBull House of Art. 


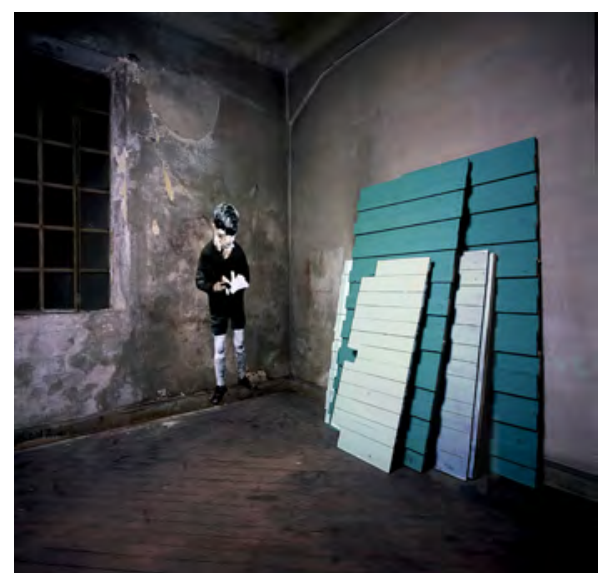

$\oplus$

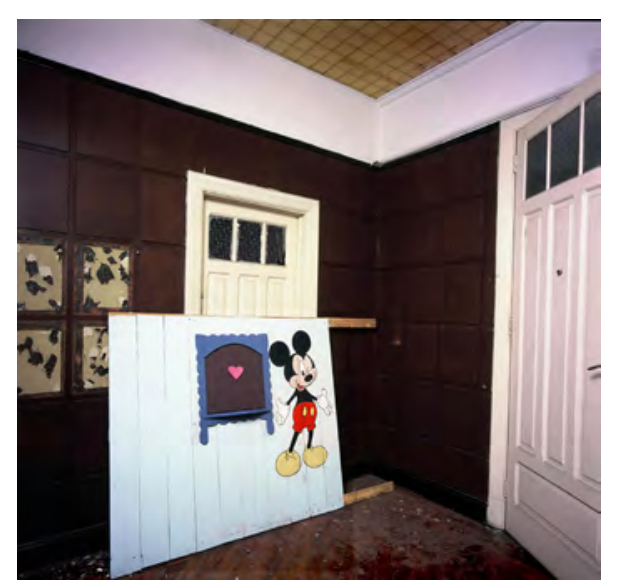

$\oplus$ 

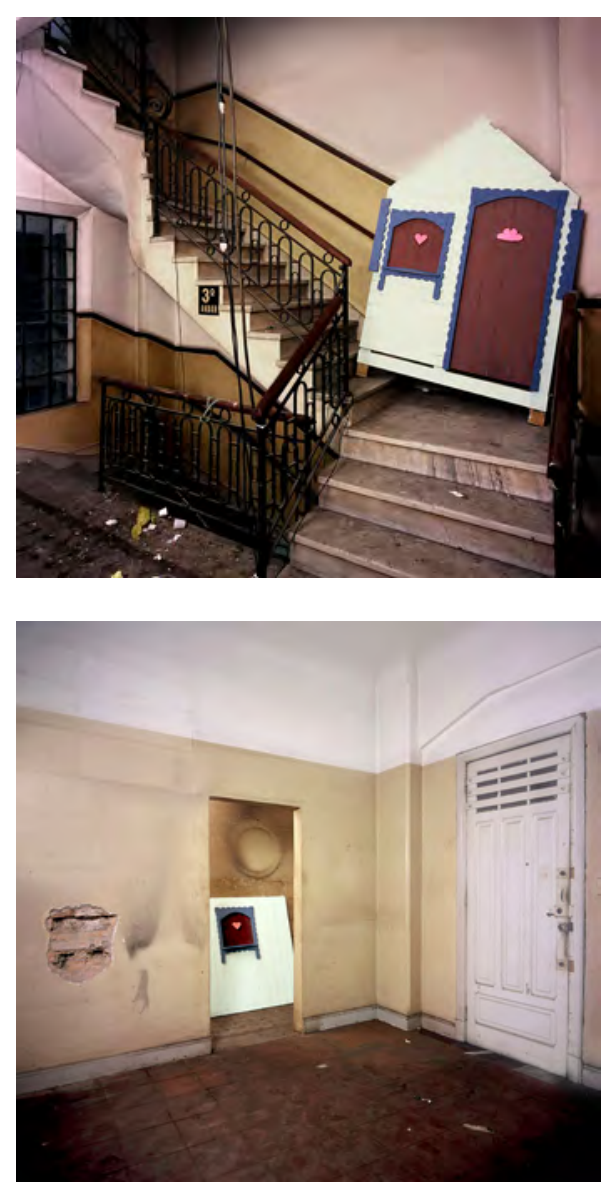


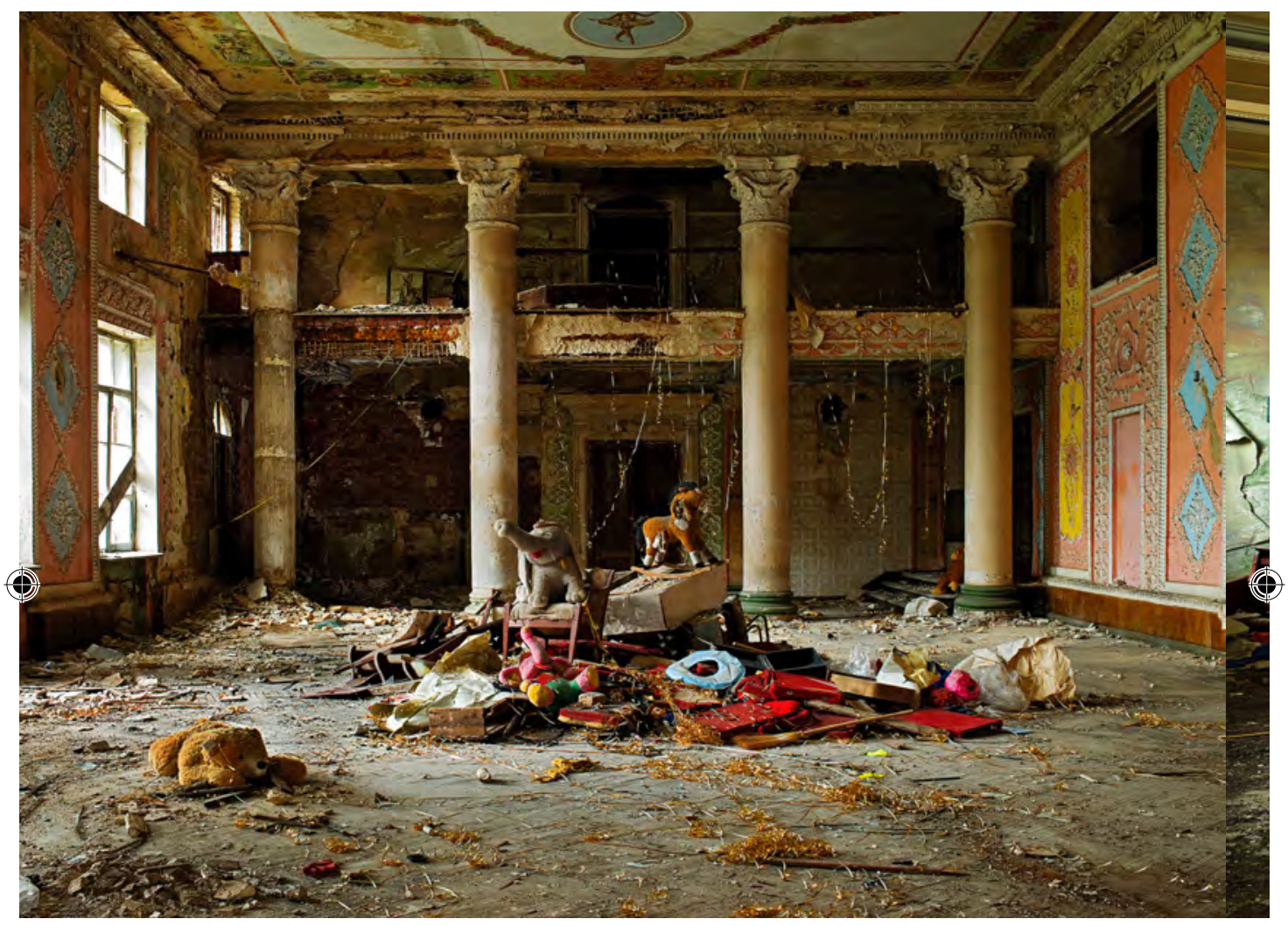




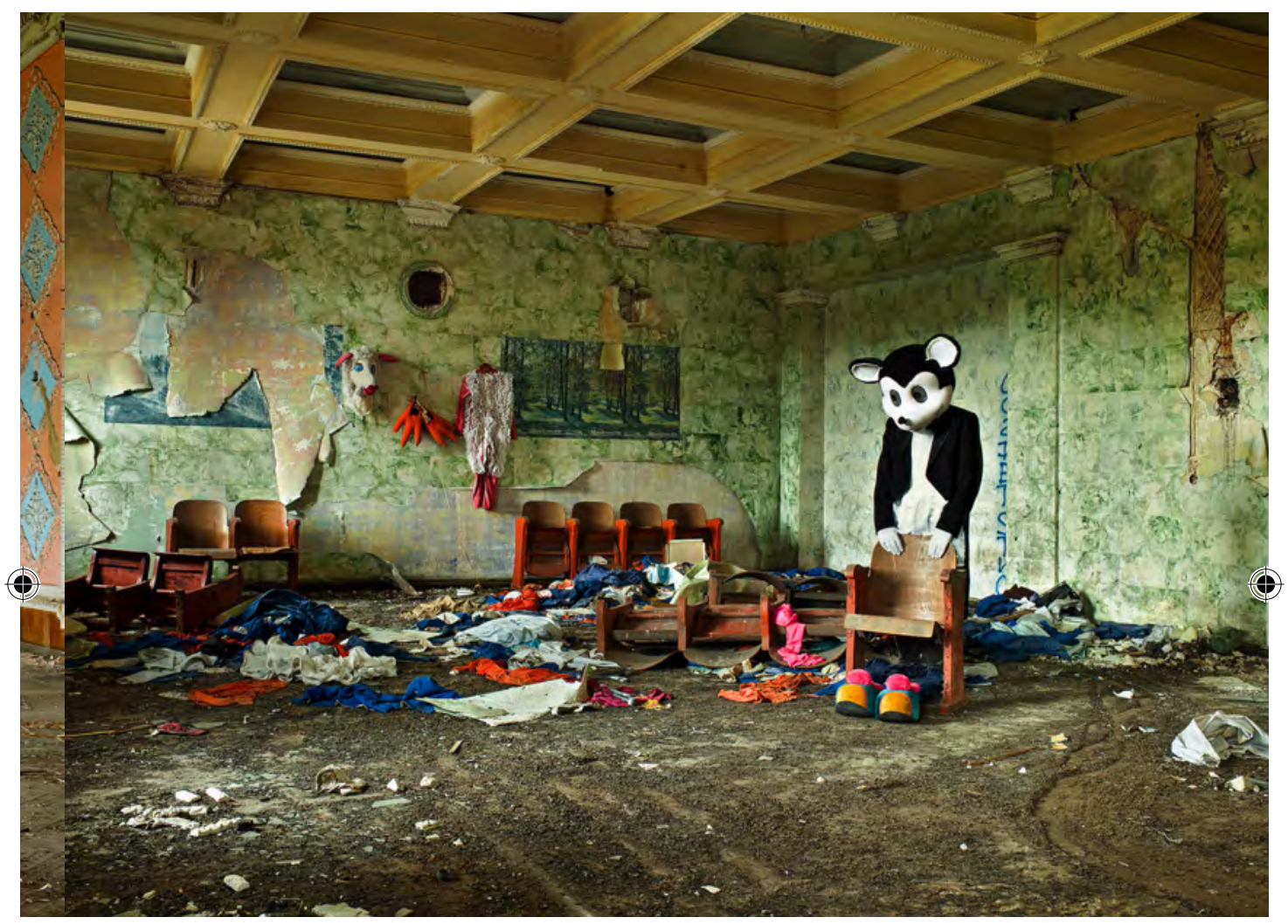

Anexo VII: Gorlovka, 1951", ampliacão fotográfica, 2011. Anexo VII: Gorlovka, 1951", ampliacão fotográfica, 2011.
Realizada durante a Residência Izolyatsia na cidade de Gorlovka, Ucrânia. 


\subsection{A FANTASIA DO OUTRO}

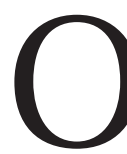

último trabalho que acredito ser importante analisar para concluir minha passagem pelos meus trabalhos anteriores, é uma instalação realizada durante o período em que participei da Residência Artística "Cité Des Arts" na cidade de Paris no final de 2011. Intitulada "O Caminho que percorri até te encontrar" (Imagem-Anexa VIII), este trabalho era composto por um série de vinte e cinco quadros que apresentavam em cada um deles, uma fotografia polaroide da imagem de um carrossel encontrado em Paris, um mapa da cidade e suas informações.

A instalação representava uma tentativa de criar uma cartografia da cidade de Paris usando como parâmetro de localização e fronteira, elementos que estivessem completamente fora dos critérios convencionais de classificação e orientação, como ruas, estações do metrô e construções.

Desse modo, eu conseguia gerar um percurso sob um olhar voltado para referências de uma memória pessoal dentro de um mapa e ao mesmo tempo estabelecer novos marcos num espaço já exaustivamente delimitado de sinalizações e caminhos traçados. No Cap. 5, irei apresentar alguns trabalhos desenvolvidos durante o mestrado que fazem parte do desdobramento da pesquisa que começou com a análise dos carrosséis em Paris.

Ainda sobre esta instalação, creio que é importante pensar na relação existente entre ela e o tema que proponho aqui: $\mathrm{O}$ carrossel, como elemento mágico da infância/ brinquedo da criança, em Paris estava presente em meio a realidade do cotidiano diário e eu apenas o encontrava imersos ao sistema comum da cidade, invertendo um processo que antes era feito de criar totalmente uma encenação ou interferir em algo que só em parte era encontrado. 
O que me leva a denominar esse terceiro momento de trabalhos de A Fantasia do outro, é o fato de que nesses últimos projetos eu já conseguia encontrar o que é cenográfico e Teatral em espaços externos a mim. É interessante pensar, que através desse recurso, nesse momento eu destituo de meu trabalho o caráter "infantilizado" único do artista, pois não crio mais a "fantasias" de modo pessoalizado e sim a encontro no espaço dos outros, evidenciando o universo infantil presente na vida que é também dos outros.

Atualmente, os novos trabalhos (apresentarei no Cap. 5) estão diretamente ligados a esse tipo de processo: são experiências que através da apropriação ou da câmera fotográfica, possibilitam relacionar os assuntos da "Teatralidade da vida Cotidiana" de um modo mais sutil e menos manipuláveis. O grande objetivo no momento é, através de meu trabalho plástico, olhar para a realidade e encontrar diferentes tipos de Teatralidade dentro dela. Com uma lente de aumento, tento investigar e propor essas constatações para o espectador que visualiza o trabalho.

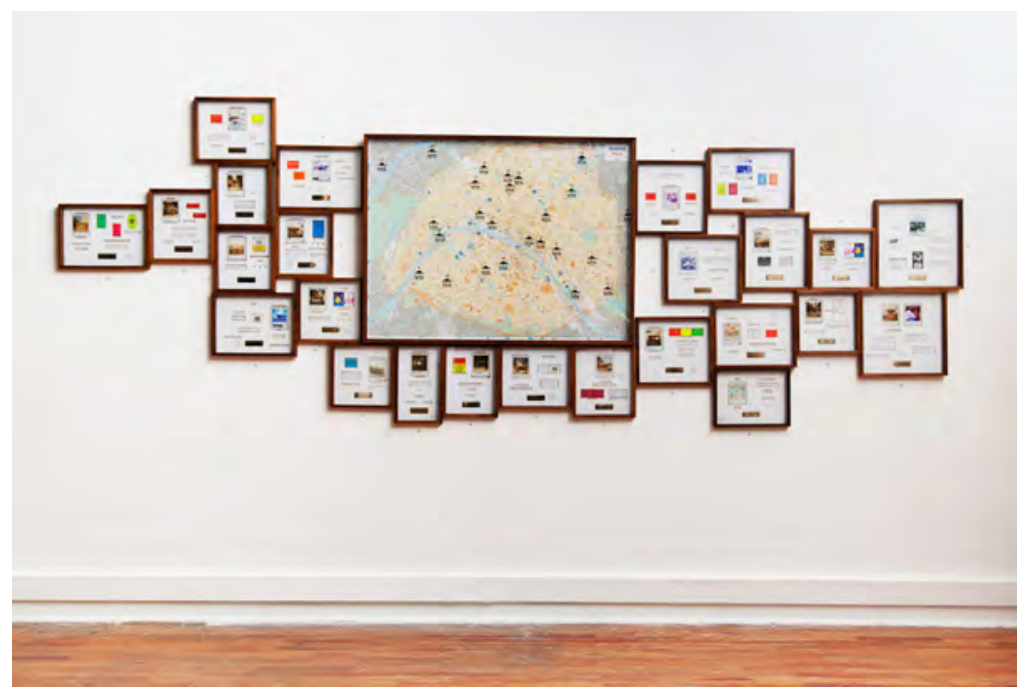




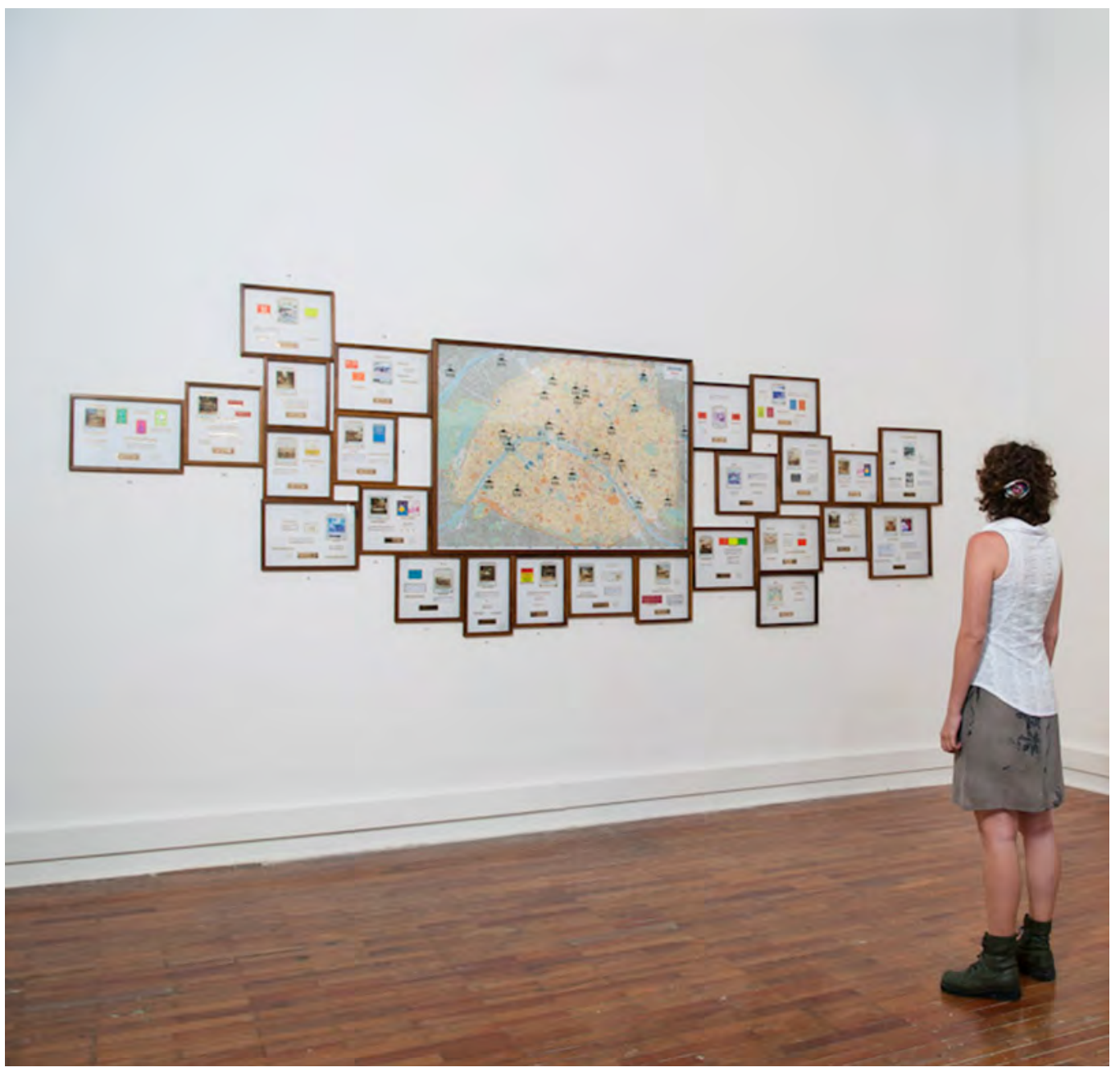



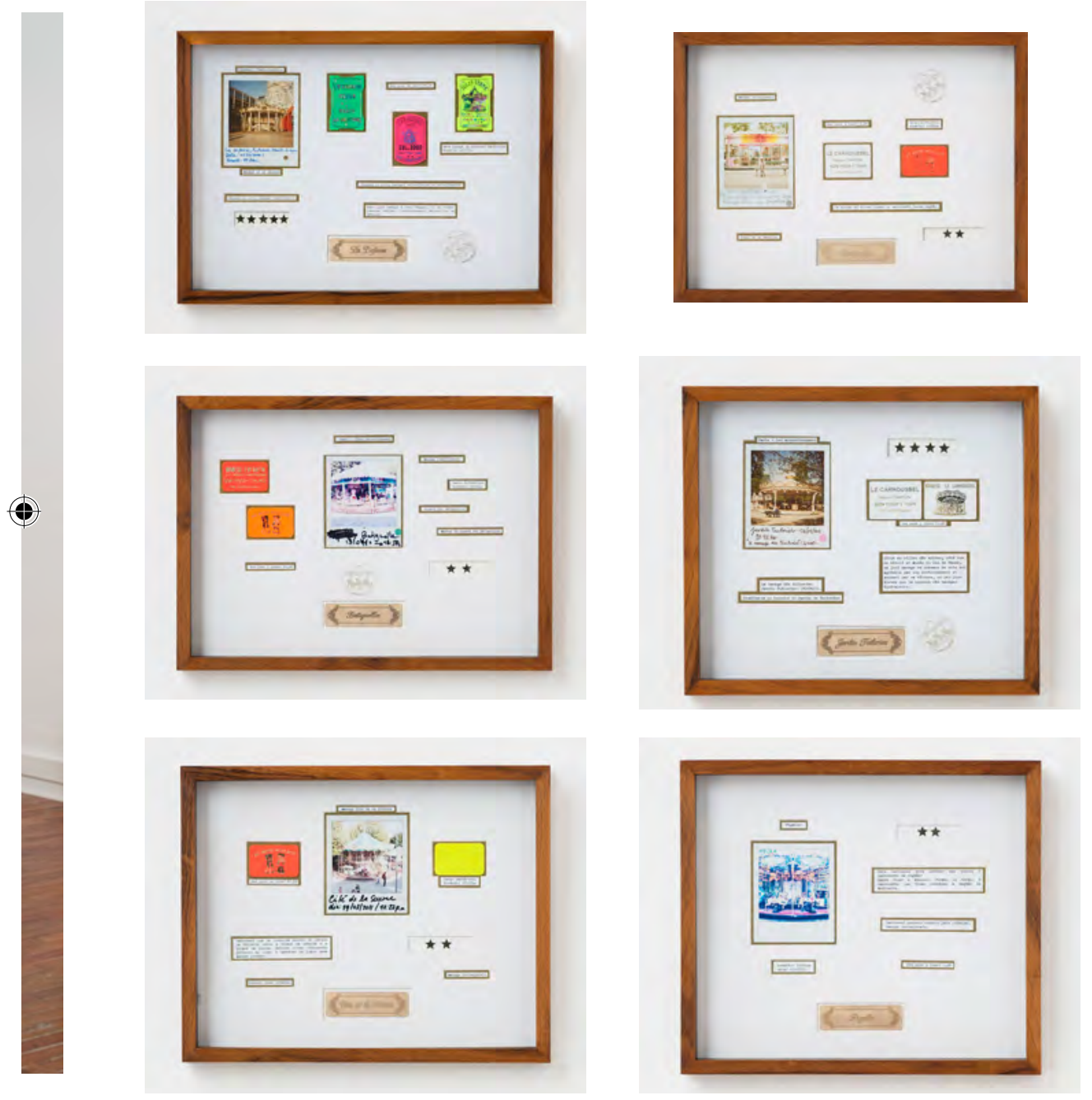

Anexo VI: "O Caminho que percorri até te encontrar", 2011.

Detalhe da Instalação apresentada no MAB-FAAP. 

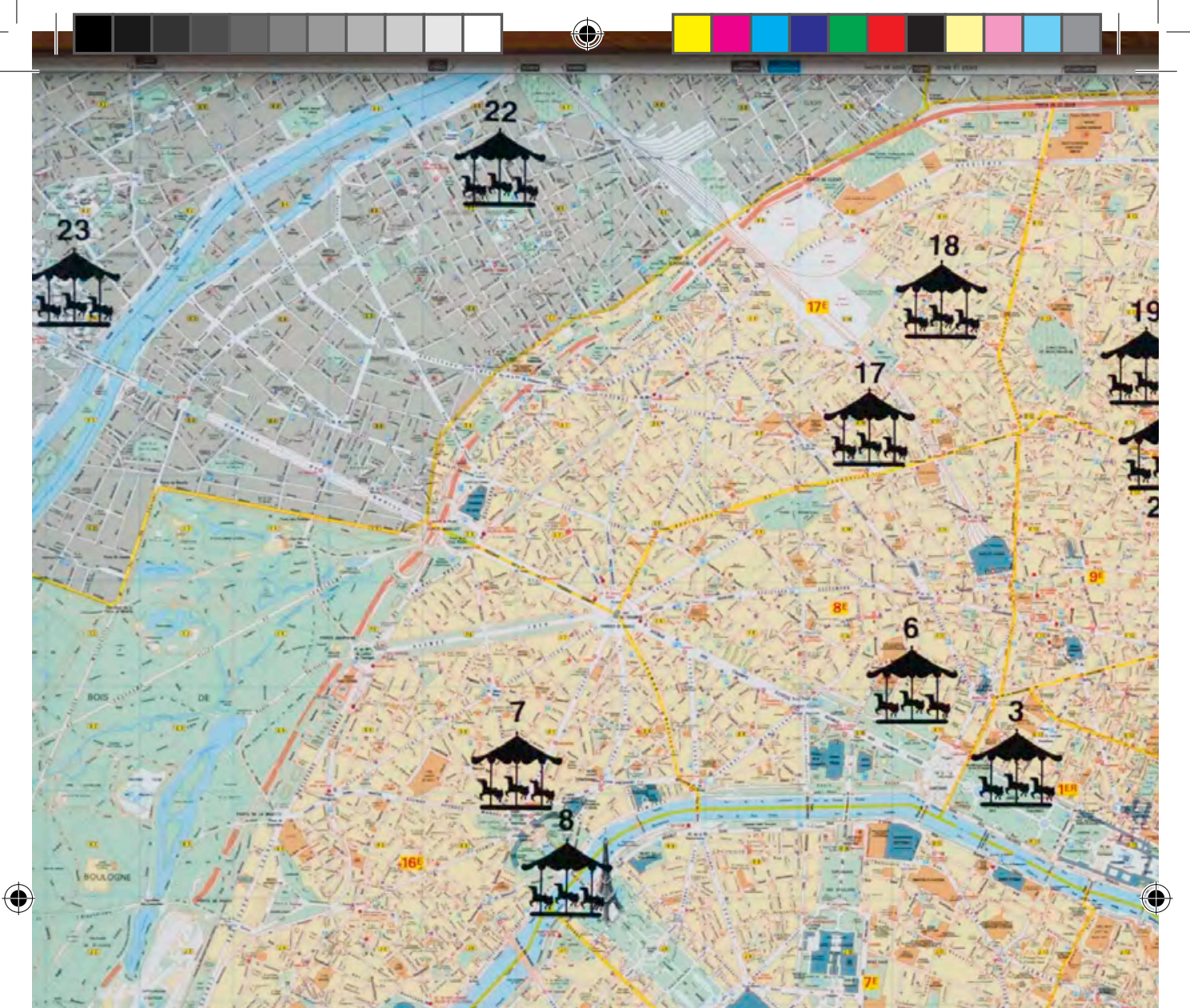

$\oplus$

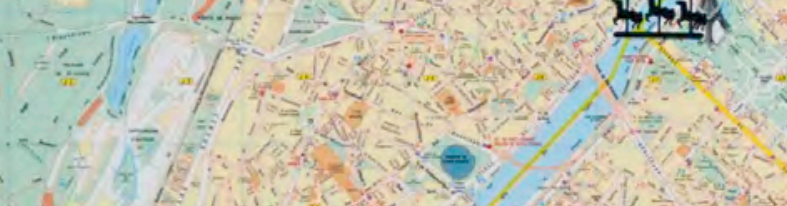

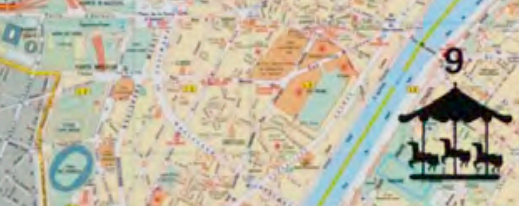

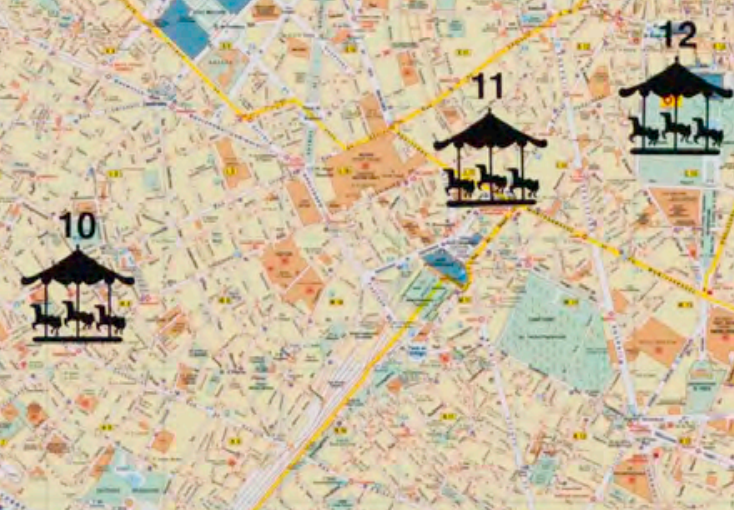

$-2 \times y=0$ 

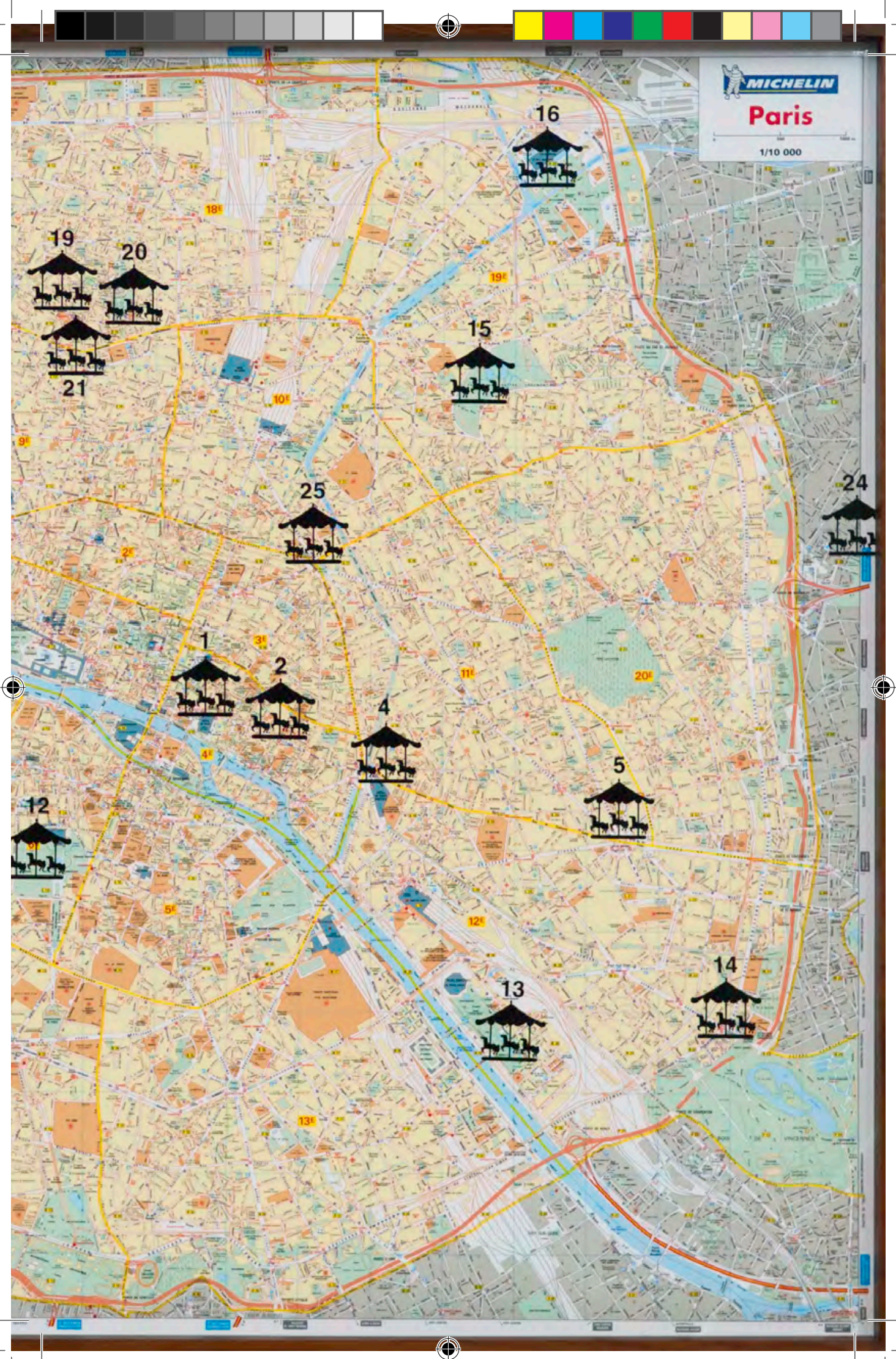

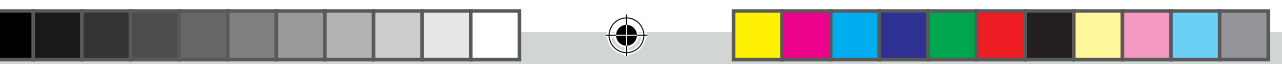

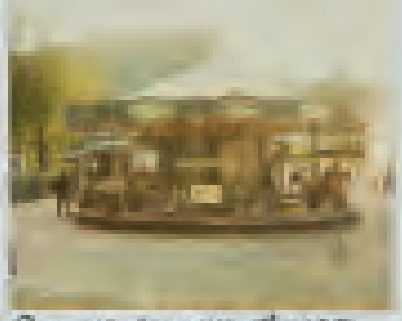

Qhe Mripous thut hit thithol the 1034

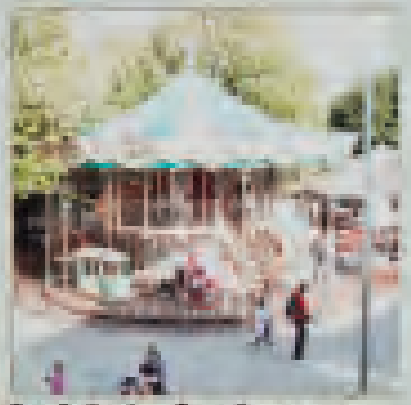

CikH 4 gurut

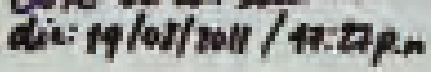

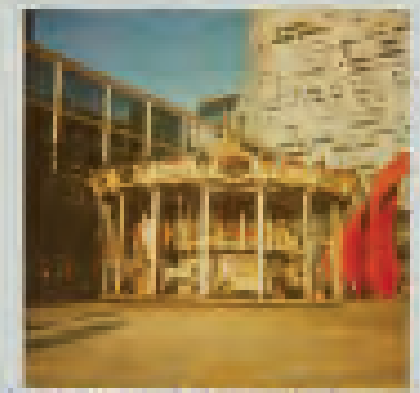

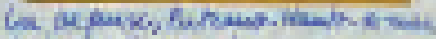

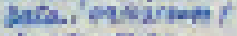

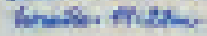

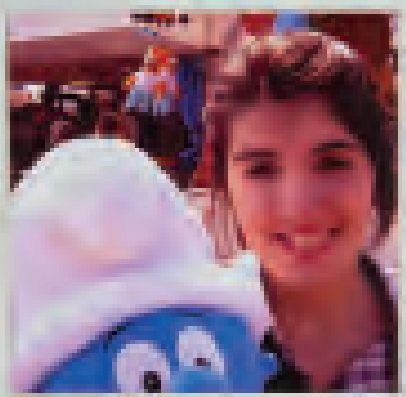

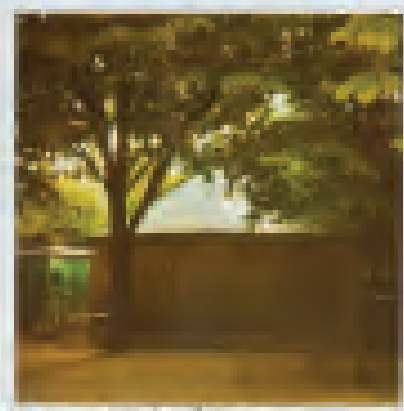

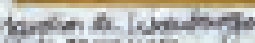

stiphist sous.

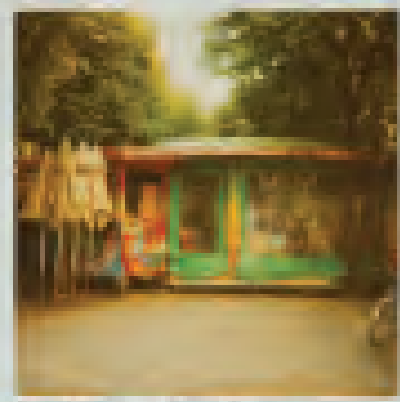

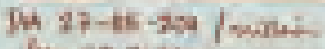

thes at난

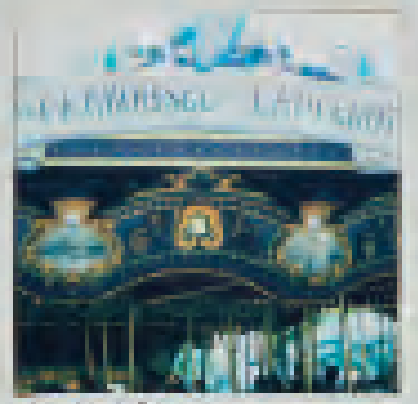

$27 / 06 / 204$

rime

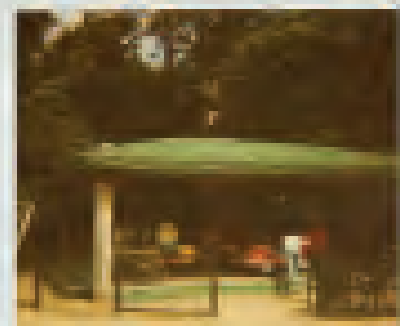

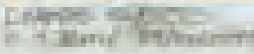

IIII

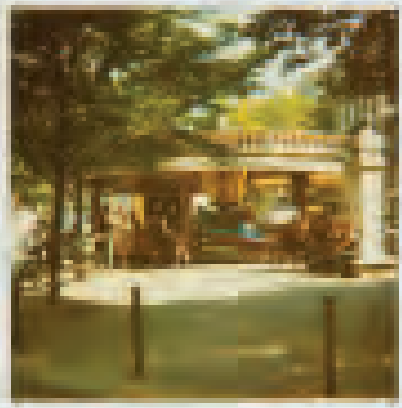

zohel ov-th-2us

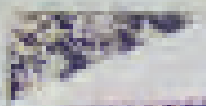

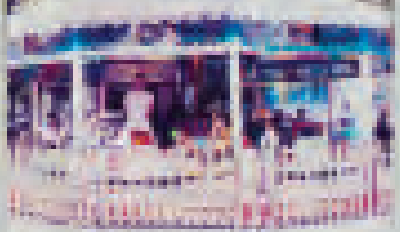
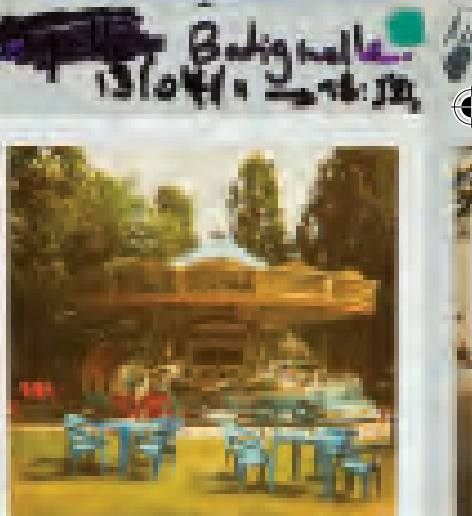

Buy dinfurdind Fapar -

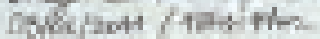

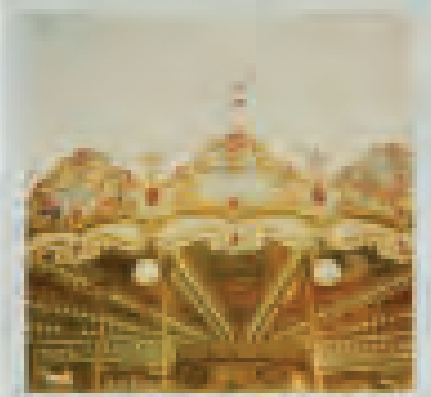

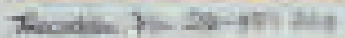
$\mathrm{Thi}_{\mathrm{i}}=$ 

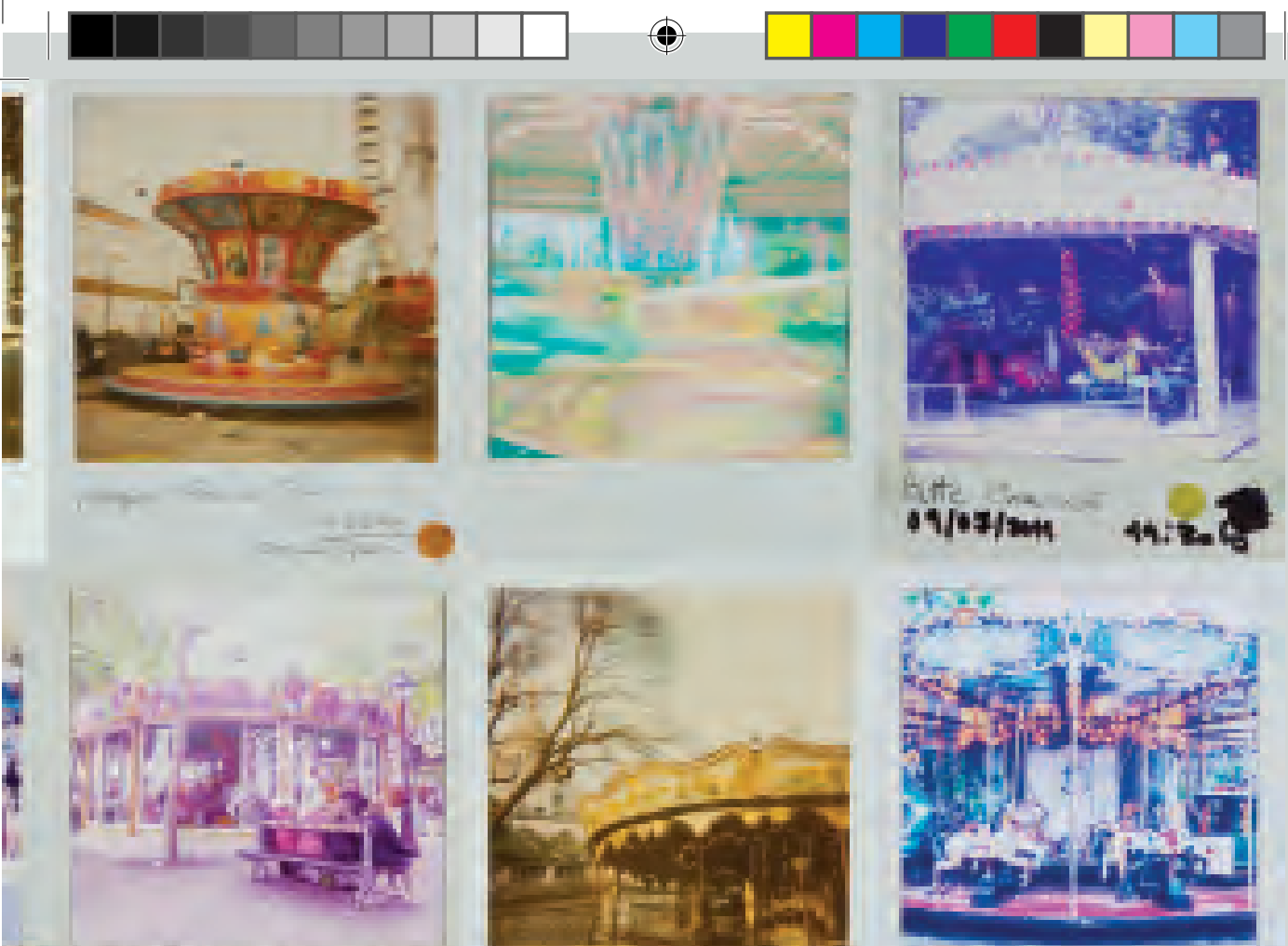

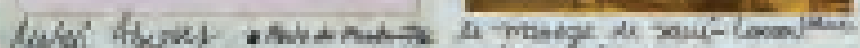

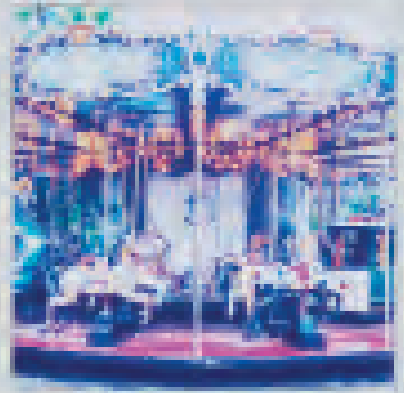

(4)

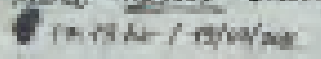

$6 \lim ^{2} a+6 a^{2}+1$

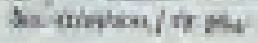

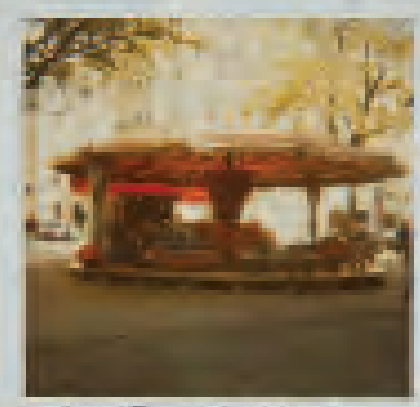

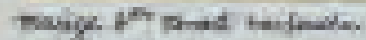
mithe niाple

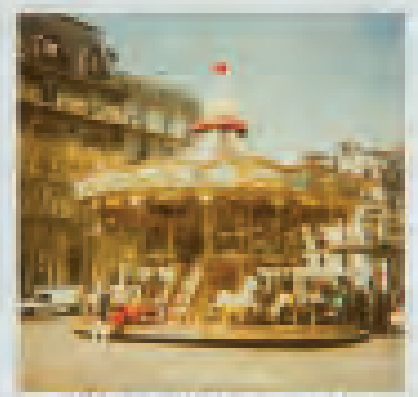

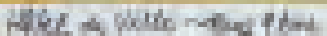

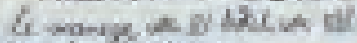
tomb Thodun
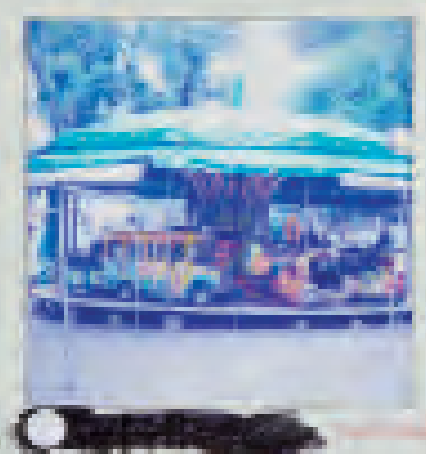

norty

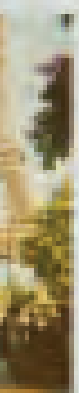

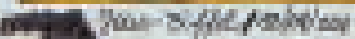

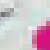




\section{3}

METODOLOGIA PARA REALIZAÇÃO

DOS NOVOS TRABALHOS.

$\oplus$

$\mathrm{m}$ 


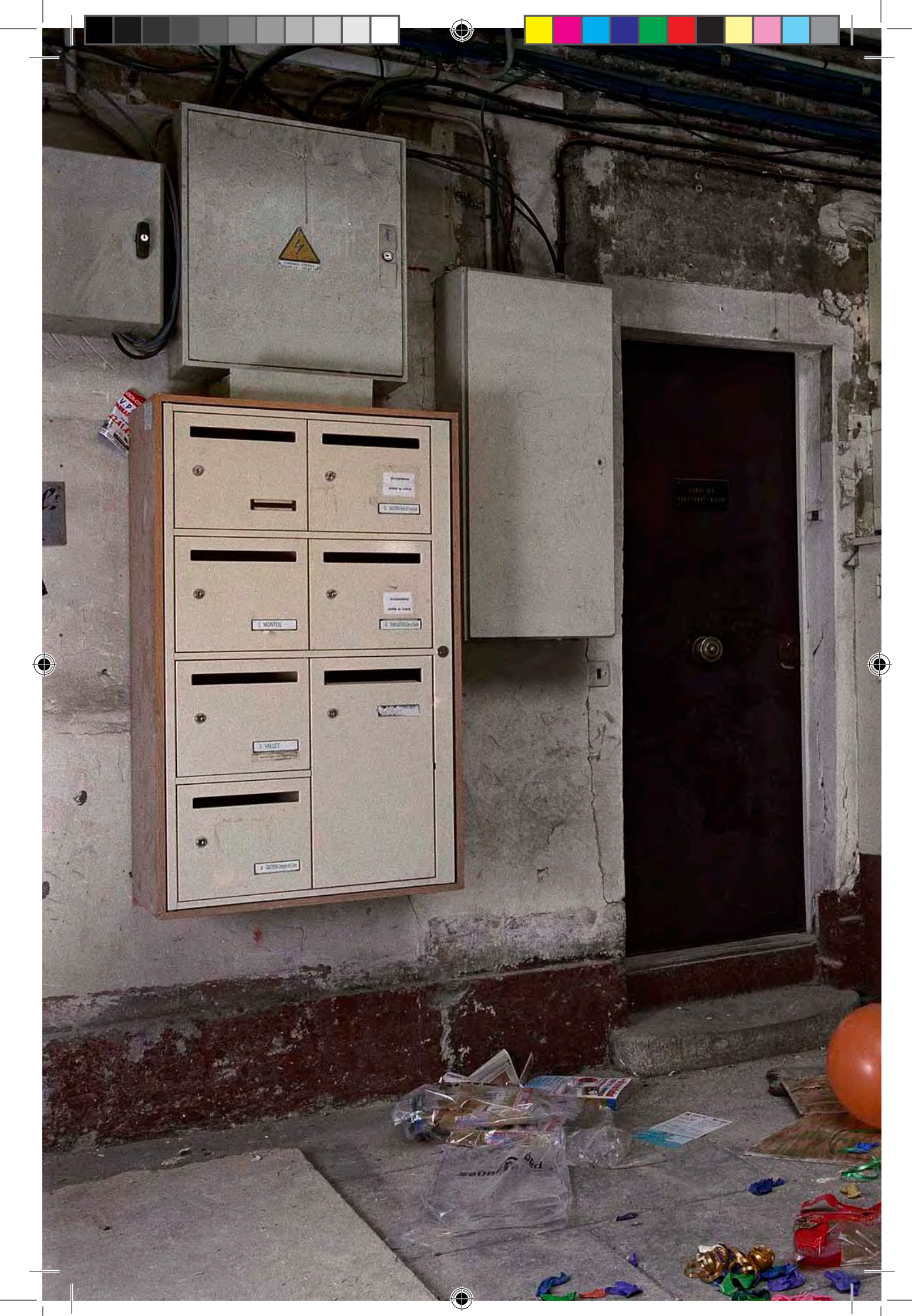




\section{A} ntes de apresentar os trabalhos plásticos que compõe 0 centro da pesquisa que foi realizada durante os dois anos e meio deste mestrado, gostaria de propor uma análise sobre as escolhas temáticas de disciplinas cursadas durante este processo acadêmico e listar quais seriam suas ligações com o que busco pontuar para reafirmar a necessidade que tenho de apresentar meus trabalhos plásticos baseados na reflexão sobre a Teatralidade e a vida cotidiana.

Ao ingressar aos estudos para o desenvolvimento do projeto inicial, decidi optar por cursar quatro disciplinas que na minha opinião dialogassem diretamente com quatro palavras-chaves características ao tema desenvolvido no trabalho. Ao refletir sobre os assuntos principais que apresento como criação visual e teórica, pude intuir que a melhor maneira para alcançar uma estrutura base para o tema da "Teatralidade da vida cotidiana", era analisar um aprendizado a cerca dos conceitos fundamentais de um vocabulário diretamente ligado a palavras que sempre estiveram presente em minha "fala como artista", mas que talvez eu nunca soubesse de fato quais eram suas origens e significados mais aprofundados.

As quatros palavras foram nesta ordem escolhidas: Teatro (Teatralidade), Antropologia (Representação do eu), Arquitetura (como espaço observado) e Fotografia. Essas definições foram aprofundadas ao longo do período para a realização dos trabalhos plásticos que aqui serão apresentados e são até agora os quatro caminhos motivadores que se entrelaçam a todo momento e geram a reflexão que tenho como objetivo desenvolver.

Minha primeira aproximação de interesse por essas palavras, deu-se através da linha de pesquisa vinda das Artes Cênicas, a aprofundar o conhecimento a cerca dos conceitos de teoria do teatro dramático e pós dramático, teatralidade, encenação e cenografia. Todos assuntos estão notavelmente, como já apresentado no Cap. anterior, presentes em minhas primeiras séries de trabalhos realizados em 2009/2010: "A conhecer os meus segredos", "Na Companhia dos Objetos" e a "A Casa em Festa", em que a 
construção da fotografia encenada de auto retratos, potencializava a um grau quase máximo a idéia de fotografia performática, a teatralidade na construção da cena e a encenação.

Ainda sobre as Artes Cênicas, creio que aprofundar questões relativas a encenação e a cenografia, de modo que eu conseguisse entender quais seriam as bases da construção cenográfica, da representação teatral e principalmente o significado destes vocábulos, foi fundamental para pensar o que constantemente era realizado de maneira intuitiva durante dois anos de pesquisa em fotografia.

Pensar sobre o conceito de Teatralidade, para além de um esclarecimento de procedimentos de construção estética do que havia sido feito no passado, tornou-se muito importante na medida da discussão teórica que também se inicia agora para pensar os trabalhos atuais. "A teatralidade da vida cotidiana", assunto de fato presente em meus trabalhos anteriores, aparece nesse momento de modo a objetivar e refletir um sentido mais progressivo para entender e criar novos trabalhos plásticos. Vale pontuar que vivenciar a experiência prática de uma aula em artes cênicas significou também entender que de fato o que interessa neste momento para a dissertação é somente a teorização da encenação e não a atuação em si.

Como disse, ainda que alguns trabalhos desenvolvidos apresentem 0 ato performático para câmera fotográfica ou a encenação e a construção de cena em prol de um ato performativo, percebo que uma das grandes vertentes presentes na heterogeneidade da prática do teatro pós dramático ${ }^{12}$ é a tentativa de trazer "0 espaço ficcional para a vivência real", algo que de certo modo vai contra ao que procuro dizer, pois neste caso o que interessa é pensar o teatro sob uma perspectiva dramática baseado na "mimesis"13

\footnotetext{
${ }^{12}$ Segundo o teórico alemão Lehmann, em sua obra Postdramatisches Theater publicada em 1999, o teatro pós moderno quebra com um controle imposto pelo teatro clássico burguês e propõe novos paradigmas para a cena e para dramaturgia (vale dizer que a cenografia, os personagens e a encenação permanecem no teatro pós moderno, porém de modo mais fragmentado permeando uma escritura cênica que demanda novos aspectos que se diferenciam ao teatro baseado na "mimesis" Aristotélica)

${ }^{13}$ Mimesis ou Mimese, significa imitação ou representação em grego. Aristóteles em seu livro Poética, rejeita o mundo das idéias e valoriza a arte como representação do mundo. Para o filósofo, o drama é a "imitação de uma ação", que em uma tragédia teria o efeito catártico.
} 
de Aristóteles, da encenação do drama como a "imitação de uma ação", representação e desenvolvimento de personagens que atuam na teatralidade de nossas vidas.

Nos capítulo "Teatralidade", desenvolverei melhor os conceitos a cerca da Teatralidade e qual definição de fato me interessa para pensar meus trabalhos, agora no entanto, creio que é importante somente frisar a escolha desta palavra chave e situála como peça fundamental para olhar sua relação com os outros três temas e os demais assuntos que serão aqui abordados.

A segunda aproximação de interesse pelas palavras chaves que propus analisar aqui, deu-se através da linha de pesquisa vinda da Antropologia, a pensar sobre o tema da "Representação do eu na vida cotidiana", título este advindo de uma das pesquisas mais relevantes do antropólogo Erving Goffman, que aplica em sua teoria conceitos do teatro ao retratar a importância das relações sociais e os diferentes papéis funcionais que nós desempenhamos ao longo de nossas vidas. Não coincidentemente, o título que nomeia esta dissertação "A teatralidade da vida cotidiana" se dá a partir da leitura deste livro que se torna fundamental para debater conceitualmente a produção plástica que foi aqui realizada e mais a frente será apresentada.

Assim como Ervin Goffman, a teoria da Fragilidade do filósofo e roteirista Jean Claude Carriére, também trata da questão da necessidade de representação de papéis como modo de "camuflagem" para garantir a sobrevivência do homem, que por apresentar uma "essência de vidro" muito frágil necessita de máscaras para sua vida real. Vale dizer que em seu texto, Carriére assume uma posição de defesa a queda das máscaras, de modo que se o homem reconhece sua fraqueza para o outro que também é fraco, ambos podem se entender com maior sinceridade e vivenciar situações verdadeiras. No entanto, o que interessa para esta dissertação é pensar na necessidade da atitude de colocar a máscara, por isso observarei apenas a parte que consiste a Teatralidade, o que chamarei pessoalmente de Teatralidade Extravagante e que irei desenvolver mais a frente. 
É importante ressaltar que em ambos os casos há uma abordagem "funcional" no que consiste a representação na vida cotidiana, como se 0 homem para garantir sua sobrevivência no próprio espaço real devesse se valer de "personagens" assim como no teatro, para atuar e permanecer em sua posição de sobrevivência. Para além desse pensamento que não é de fato o foco de meu interesse, a essência do que me chama a atenção para olhar esses dois teóricos é em observar a melancolia que há na consciência da "fraqueza" e quais são as estratégias quase "espetaculares" que se valem os homens para não só se manterem erguidos diante de seu cotidiano, como também e principalmente para fugir dele.

Na minha opinião, mais do que usar da representação para se ajustar ao cotidiano (o que se aproxima mais do pensamento desses teóricos) o foco é pensar que é também através destas mesmas máscaras que os diferentes homens ou sociedades se utilizam para gerar situações de fuga do cotidiano, através de "embelezamento" e "idealização" da vida comum, com o objetivo de tornar o cotidiano menos repetitivo, funcional e objetivo.

Valendo-se assim de uma Teatralidade, a que chamarei aqui, mais extravagante: A exemplo os rituais e costumes que mudam de uma sociedade para outra, as tradições festivas e ritos de passagem, celebrações religiosas, viagens e parques de diversão focados nas férias e até mesmo figurinos, cenários, objetos, adereços, decorações e brinquedos, são algumas das infinitas estratégias que me interesso, observo e muitas vezes evidencio em minhas fotografias.

É importante nesse momento frisar a minha consciência para a idéia simplista de propor a existência de dois atributos a que tenho chamado "vida real $\mathrm{x}$ vida ficcional", o que seria uma aparente "limitação" e também uma certa "ingenuidade" no sentido de idealização dada a representação ficcional, como se ela sozinha pudesse resolver algum tipo de problemática da vida cotidiana.

Dando seqüência ao pensamento das quatro palavras chave, creio que após me certificar dos conceitos relacionados a teatralidade e a representação do eu, em um novo momento optei por 
um conhecimento que me mantivesse mais atenta a uma contextualização de procedimentos práticos vindos diretamente da pesquisa em artes plásticas e dos espaços onde ela atua. A fotografia e a arquitetura surgiram de modo a completar o pensamento sobre a "Teatralidade da vida cotidiana" ao gerar instrumentalização para que possíveis observações pudessem existir formalmente durante 0 processo de produção e gerassem novos trabalhos.

A começar pela arquitetura, conceito que para esta dissertação significa espaço de observação real do cotidiano e construção estética espacial da imagem fotográfica. A arquitetura nesta pesquisa entra no momento em que se estabelece como toda e qualquer manifestação estrutural e visual. A grande parte do processo criativo apresentado neste trabalho se dá através de uma observação vinda do espaço primeiro a que chamo o interior da casa (a pensar na memória dos objetos da casa, na "cenografia" da casa e principalmente na "sobre - cenografia" através das festas de família que acontecem dentro da casa) e também de um espaço a que chamo secundário que seria o externo à casa (a pensar aí em uma ampla gama de espaços e objetos que tem como intuito, ao melhor olhar bastante particular, "ficcionalizar" a realidade).

Já a fotografia, mais do que nunca é o instrumento/ conhecimento que reforça as questões abordadas pelo tema que proponho na dissertação. A "teatralidade da vida cotidiana" está quase como ímã colada na fotografia, pois é na foto que encontramos ou não encontramos o que é real e o que é encenado e vice-versa: ainda que haja a foto documental, mesmo assim, nunca saberemos com plena confiança quais são as "verdades" dos fatos presentes nas imagens fotográficas, pois as fotos podem ser (cada vez mais nos dias de hoje) uma mera construção cenográfica que torna visível ou invisível, o que nos convêm fazer com que exista.

Sabe-se que a fotografia concentra ao longo da história a discussão dicotômica entre o espelho do real e a transformação da realidade. Deste modo ao apresentar a foto como um dos suportes e estratégias mais importantes de minha pesquisa plástica, procuro 
dissolver essas fronteiras e sobrepor os diversos significados com que os conceitos de real e ficção já foram definidos. Nessas intersecções, busco perceber o desejo subjetivo de concretizar experiências ficcionais que organizam-se de diferentes formas em cada espaço e são diretamente ligados ao meu cotidiano.

E interessante pensar que em muitos de meus trabalhos anteriores, realizados em 2010 e 2011, a construção da fotografia era basicamente um acúmulo de objetos performatizados para a concretude de uma imagem com o intuito de recriar situações inexistentes e de certo modo confundir o espectador para o que era real ou não, a pensar quais objetos já estavam ali e quais eram montagem. $\mathrm{O}$ objetivo não era somente confundir, porém me valer desse atributo, era também reforçar algumas questões que eu gostaria de enfatizar nesses trabalhos.

De maneira geral, sob uma perspectiva de conjunto, vejo nestas quatro palavras-chave principais: Teatro, Antropologia, Arquitetura e Fotografia, uma união quase narrativa de um processo que repercute a maneira pela qual tenho produzido atualmente. Noto que é através da teatralidade que desempenhamos diferentes "personagens" no cotidiano, seja em função de uma necessidade, seja por extravagância e necessidade de fuga da realidade. Por conseqüência, é através da observação, principalmente com a câmera fotográfica, que tento estabelecer a reflexão estética de um conteúdo que se manifesta na arquitetura cotidiana da casa, dos parques, das praças, ruas e muitos outros locais em que a idealização e realidade se enfrentam lado a lado de modos mais explicitados.

Em suma, é através desses quatro elementos que sugiro a união do conteúdo teórico e prático para embasar os trabalhos plásticos que foram realizados durante o período desta dissertação. E importante lembrar que grande parte da bibliografia apresentada nesta dissertação vem das aulas cursadas nestas disciplinas, indicações de meu orientador e também de algumas referências informais como jornais, revistas, filmes, publicações e catálogos de exposições que foram sendo acumulados ao longo deste período. 
É importante também dizer sobre o processo artístico de produção das obras, que muitas vezes confuso e contraditório, obrigava-me a realizar alguns projetos que não andavam conjuntamente as descobertas teóricas. Creio que este é o curso comum do processo artístico, que ora se completa e ora se anula numa grande busca para saber quais são os assuntos de pesquisa de um ou outro momento.

Digo isso, pois creio que o trabalho do artista ao embasar seu tema, não é criar uma teoria para si, mas se valer das teorias de autores que discutem temas próximos, para através deles dar continuidade aos seus pensamentos e formalizações plásticas. Desse modo, os trabalhos que apresento nesta dissertação foram aqueles que, sob a luz de alguns conceitos escolhidos, dialogaram mais claramente com o que desejo discutir.

A grande maioria dos trabalhos anteriores que me fizeram chegar ao tema da "Teatralidade da vida cotidiana" foram realizados através da fotografia, porém neste momento alguns dos trabalhos que apresento não são necessariamente concretizados através do mesmo suporte. Ainda assim, creio que analisar a manipulação da técnica fotográfica como processo para o desenvolvimento do trabalho é fundamental para pensar os conceitos embutidos na proposta da "Teatralidade da vida cotidiana" que são basicamente "realidade" x "ficção", "representação e objeto representado" e o "visível e o invisível".

Desse modo, creio importante firmar aqui duas considerações que já foram descobertas: a primeira é que os três pontos mais significativos para pensar meu trabalho atual são: a Teatralidade, a Infância e a Fotografias, ambos existem e se relacionam fortemente com o conceito de Ficção e Realidade. E além disso, é importante pensar que em meu processo criativo há presente quatro palavras chave: A Teatralidade e Representação; A Arquitetura e Fotografia.

Antes de passar para o próximo capítulo, gostaria de fazer uma consideração a respeito de minha qualificação. No ano passado, conversando com minha banca do exame de qualificação, resol- 
vi tomar a decisão de reduzir grande parte das referências teóricas que compunham a pesquisa de mestrado e dar ênfase nos trabalhos de artes plásticas realizados durante este momento e principalmente entender meu processo, estabelecendo relações com as produções realizadas anteriormente.

É importante ressaltar esta decisão, pois a dissertação passa a acontecer prioritariamente como uma fonte de reflexão textual a cerca dos trabalhos visuais. Como sou artista, não tenho a pretensão de criar grandes teorias, nem tão pouco discursar e escrever com domínio para fazer algo que seria do campo da literatura e da filosofia. Desse modo, a idéia aqui é percorrer o trabalho, demonstrando meu modo de pensar e observar o mundo externo a partir de meu olhar como estudante de artes. 

A TEATRALIDADE DA VIDA COTIDIANA 


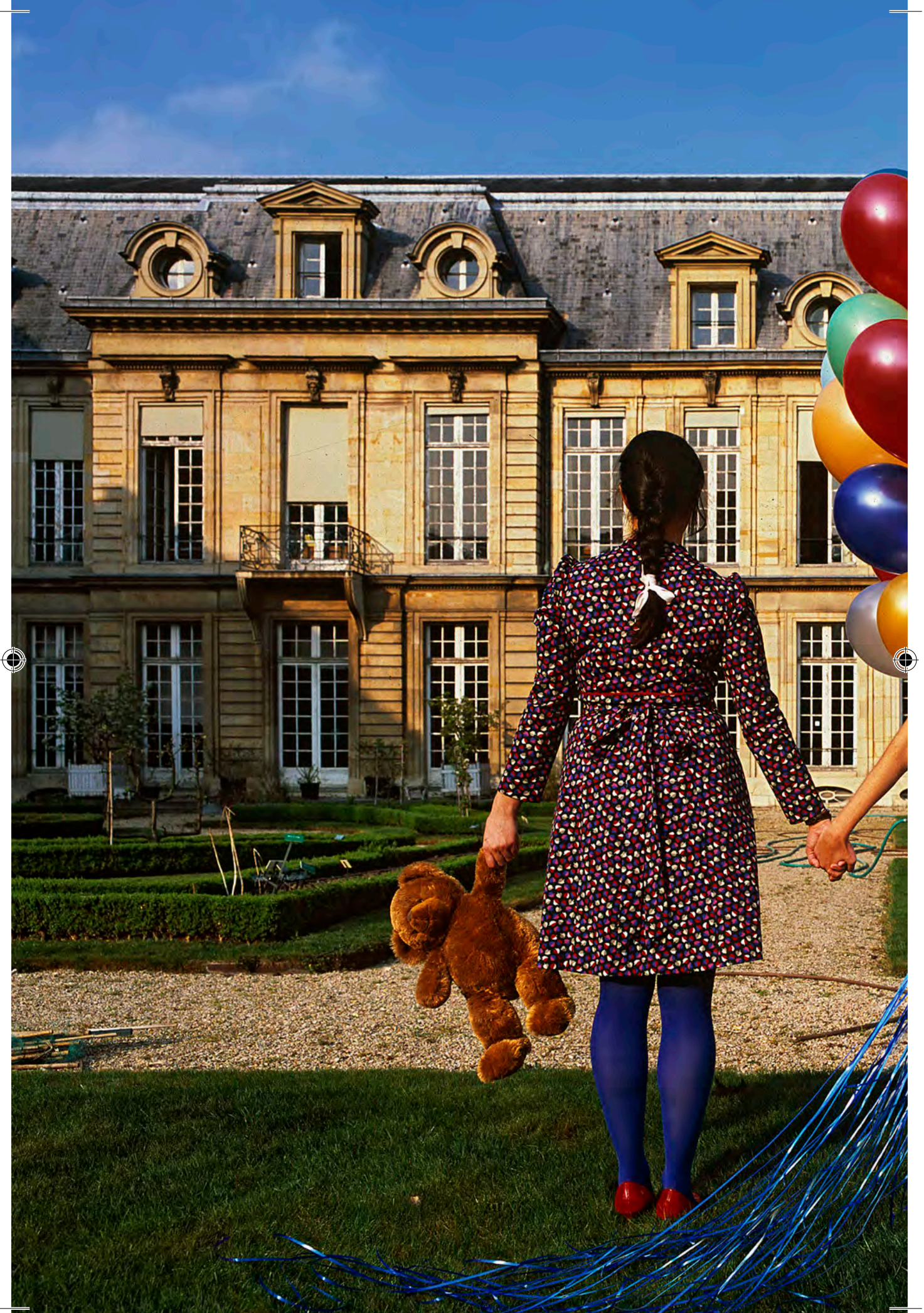




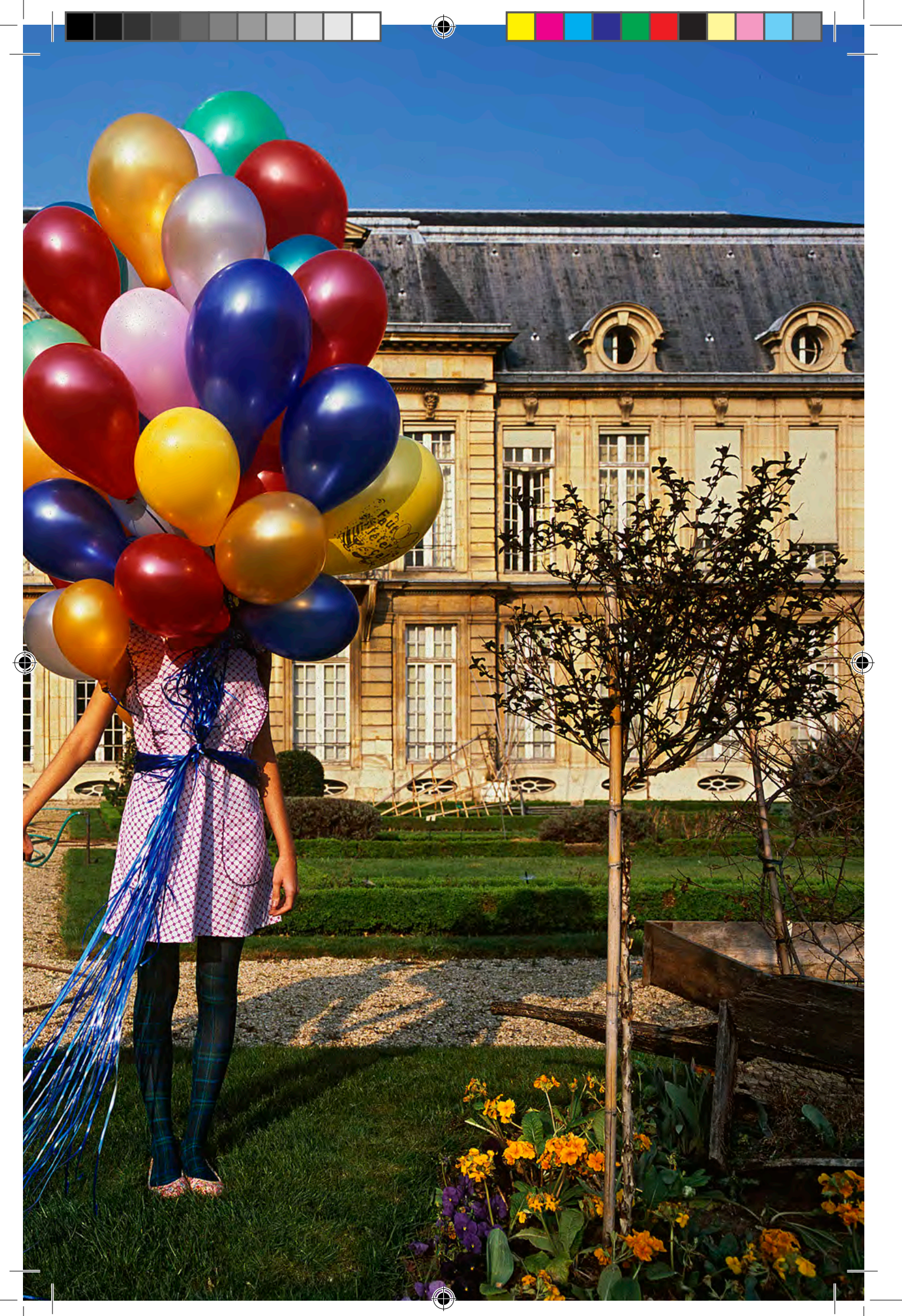




\subsection{REALIDADE X FicÇÃo Na TEATRALIDADE.}

- 0 do indivíduo tem necessidade de compor e se transformar através de sua Teatralidade. Na vivência do cotidiano, todos teatralizam pelos diversos cantos: nas ruas, cidades, nos diferentes lugares e igualmente aguardam seus semelhantes, que podem ser um espectador, um cliente, um comprador ou uma companhia para dar sentido a sua vida.

Para isso, o indivíduo que está no cotidiano, assim como o personagem de teatro, também segue um ritual, veste seus personagens, se pinta e se prepara para um encontro que é completamente fora do teatro; um encontro com a vida comum.

A Teatralidade de cada dia revela as mais diferentes facetas. São camelôs que inventam personagens para atrair compradores, devotos que pregam suas religiões capturando fiéis nas praças, jovens fazendo malabarismos nos sinais de trânsito, vendedores, contadores de histórias, ciganas com roupas coloridas, homens de perna de pau, políticos e militantes que fazem campanhas, músicos que se apresentam nas ruas, atores vestidos como se fossem estátuas, andarilhos, loucos, donos de carrinhos de cachorro quente, prostitutas e travestis. Todos disputam atenção, visibilidade e garantia de sua sobrevivência ao representar seus papéis. Mas, ainda que existam todas essas situações de Teatralidade no cotidiano, 0 foco deste trabalho não é olhar para o desenvolvimento dos papéis funcionais dos seres humanos, ainda que alguns sejam mais fantásticos que outros.

O foco de minha pesquisa consiste em pensar em uma Teatralidade que é contrária a funcionalidades objetivas que são presentes na vida real. Ou seja, para mim é importante observar situações em que ficcionalizamos nossa realidade como estratégia 
para "fugirmos" dela, tornando o lado mecânico de nosso cotidiano algo mais leve. Isso porque o ser humano não atua só para sobreviver, como também para criar metáforas, fantasiar, inventar esteticamente novos espaços e tempos. Essa necessidade que o indivíduo tem de se reinventar diante da velocidade do cotidiano de todos os dias é o que chamarei aqui, de modo pessoal, de Teatralidade Extravagante. Esse é o tipo de Teatralidade que me interessa.

Exemplos mais próximos desta fuga do que é real, são situações ligadas aos rituais como: procissões de santos, rituais de terreiros, folia de reis, fantasias para o carnaval, mágicos, palhaços, coelhos da páscoa, Papai Noel, festas diversas, entre inúmeras outras situações em que o indivíduo cria para melhor vivenciar a dureza dos dias.

Neste jogo de desempenhar papéis, teatralizamos nossas relações diversas em todo o campo do cotidiano. Pensar para além das situações de Teatralidade é pensar também nos objetos de teatralidade, que vem de um resquício da cenografia teatral, como por exemplo, os objetos utilizados nas festas (rituais de passagem da tradição) ou os objetos das crianças (afinal, como já disse na introdução, é na infância que se tem 0 apelo estético do universo da magia e do sonho, do conforto que está presente na "mentira").

Esses objetos existem também no universo adulto, ora criado pelos adultos, ora próprio da crianças, porém também a contaminar o espaço adulto. É interessante para mim como artista, observar essa contaminação de objetos próprios da Teatralidade presente em meio a vida real, seja no espaço arquitetônico das cidades, nos espaços de diversão, na estrutura familiar, entre tantos espaços divergentes. Essa relação de espaços cria um caminho que se coloca entre o interior e o exterior do indivíduo que se relaciona com o universo da Teatralidade.

Como diz Danilo Santos de Mirando em seu livro "essencialidade e representação", a teatralização, assim como outras formas criativas de representação, constitui um deslocamento para um território intermediário no qual se entrecruzam a interioridade 
do indivíduo (expressa em sua interpretação sobre o real) e a concretude mais evidente dessa mesma realidade. Por esse processo, o fazer artístico traduz o não revelado, fazendo a mediação entre os distintos (mas não estanques), planos de ser".

Não é à toa, por exemplo, que os aparatos cênicos (cenário, figurino, iluminação e música) utilizados durante a passagem do ritual do casamento, sejam em sua grande maioria das vezes, a repetição estética contida nos finais felizes de contos de fadas. O que só reforça minha constatação de que muitas passagens da realidade da vida cotidiana do homem, embebedam-se não só da representação teatral, como também do desejo de concretizar suas consequências ficcionais. Desse modo, se cria um estado entre a realidade e a ficção, que faz parte do indíviduo enquanto seu estado interno e o coloca em espaços externos, que misturados criam um novo estágio de aproximação.

Meu interesse por hora não é tomar partido de valor sobre estes "tipos" de experiências de vida, muito menos julgá-los como infantis ou imaturos, cínicos ou sinceros. É natural pensar em uma aparente artificialidade presente nestas estruturas, porém apesar de notar um afastamento da realidade, é justamente através e por causa dela, que toda esta dinâmica de fato ocorre.

Em minha pesquisa, a análise dos elementos estéticos das estrutura dramático/teatral existentes na encenação da vida cotidiana é o que me interessa, pois entender a fundo os motivos que ocasionam esta estética, são assuntos para sociologia e psicologia, aos quais não desejo me aprofundar.

Para mim o que importa é que a forte relação entre a experiência teatral e a experiência real está constatada e ao pensar nisso é inegável evitar a leitura sob a perspectiva de que nestes casos encontra-se uma estrutura clara de sujeito/personagem, intermediados por uma utopia de ação cotidiana/representação, que estão situados em um cenário/espaço físico.

Na minha opinião, a teatralidade dramática é algo que apesar de ser distante do real, ter caráter representativo de ações e a 
aparente artificialidade em seus meios e recursos, vale-se de seus mé todos para inferir na vida cotidiana como maneira de realização e idealização de situaçôes, o que nos possibilita uma vivência mais fácil e prazerosa.

Enfim, no cotidiano da vida, os indivíduos teatralizam de diferentes maneiras, seja para aceitar papéis fixos determinados, seja para intensificar o jogo e fazer deslizar seus papéis. Ora para driblar tristezas e opressões de diversos tipos, cria outras peles para atravessar as incertezas e impermanências. Mas as criamos também para escapar ao que se impõe como habitual e familiar, como certeza e permanência. Vestimos personagens, nos maquiamos, nos reinventamos no dia-dia para desempenhar papéis, mas semelhantemente, para libertar deles.

Para concluir, gostaria de citar um acontecimento real que ilustra na prática um pouco desta aparente dicotomia Realidade $\mathrm{x}$ Ficção a que venho tratando até aqui. 0 exemplo, por ser extremo e incomum, facilita sua verificação conceitual. Se trata de uma matéria encontrada no site vírgula sobre uma família que se fantasia de personagens da Disney no funeral de seu filho como modo de homenageá-lo.

Também, apresento uma breve passagem a respeito do filme infantil de 1988 intitulado "BIG" (quero ser grande), que apresenta a relação entre a realidade e idealização da infância sob uma perspectiva de um menino de 13 anos que pede para crescer, tem seu pedido alcançado, mas necessita conviver com a realidade adulta a partir de seu ponto de vista de criança. 

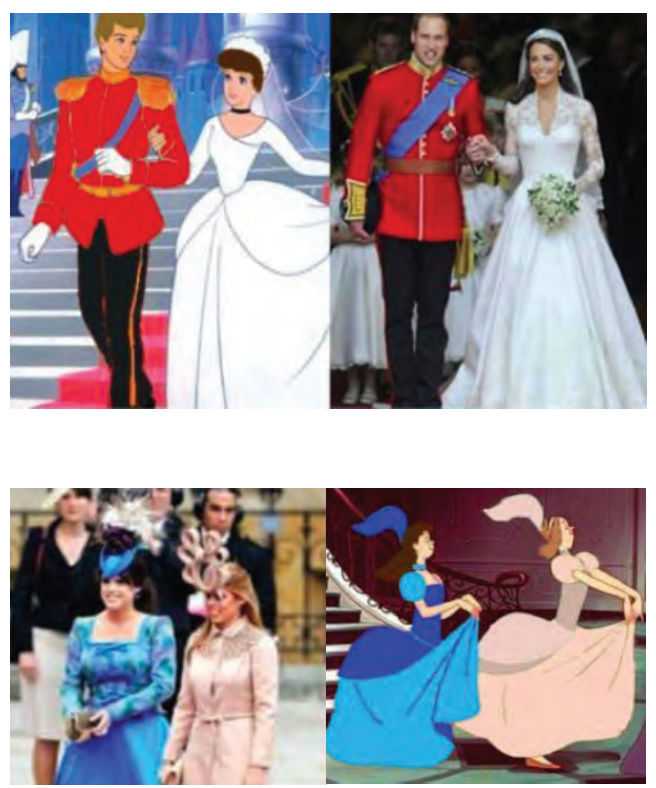

$\oplus$

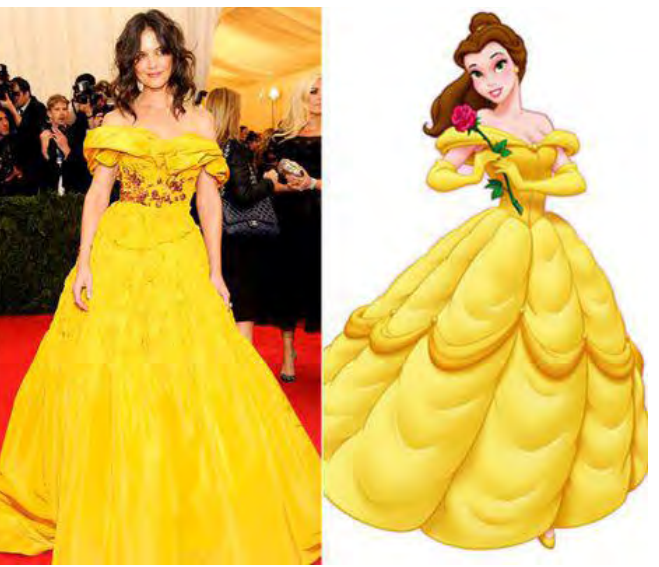

${ }^{14}$ Fotografias encontradas na internet: associação de imagens que relacionam o figurino do casamento do príncipe inglês e o figurino do conto de fadas de cinderela ou a personagem "Bela" do filme de princesas da Disney "A Bela e a Fera". 


\section{"FAMÍlIA ORGANIZA FUNERAL COM PERSONAGENS} DA DisNey PARA BEBÊ"

ntitulada "Família organiza funeral com personagens da Disney para bebê" 15 , a matéria de internet publicada pelo site vírgula no dia 07/02/2012, trata de uma família que resolve prestar homenagens a seu filho morto pelo câncer. Para homenageá-lo, sua família decidiu se vestir como seus personagens preferidos de TV durante o funeral. No dia do ritual, Mickey, Minnie e seus amigos seguiram o cortejo.

A imagem documentada, infinitamente mais interessante que o motivo que o levou a ser realizada, mostra o impacto entre a realidade e a clara intenção de dramatização. Ainda que neste exemplo extremo haja uma forte necessidade da família em fantasiar a realidade que não poupou seu filho da morte, há uma beleza e uma situação sinistra que em suas polaridades mediam a situação: As fantasias de teatro infantil, ainda que próprias da representação, existem como presença e participam verdadeiramente do cortejo. Já o carro fúnebre, austero e doloroso, carrega o peso real da morte.

Ainda que consciente da tragédia, "Mickey" permanece sorrindo em sua estaticidade de fantasia, a máscara aqui, cumpre seu papel fundamental e o jogo cênico de representação possibilita que através da máscara haja uma literal e figurativa fuga da realidade.

Conclusivamente suponho que Mickey cumpre seu papel e a idealização do ritual torna a família um pouco menos infeliz. Por outro lado, observar a cena de Mickey e seus amigos sorrindo, diante da tragédia dos outros que são eles próprios, torna o cenário um quanto bizarro: um deslocamento estranho com a realidade nos torna melancólicos. 

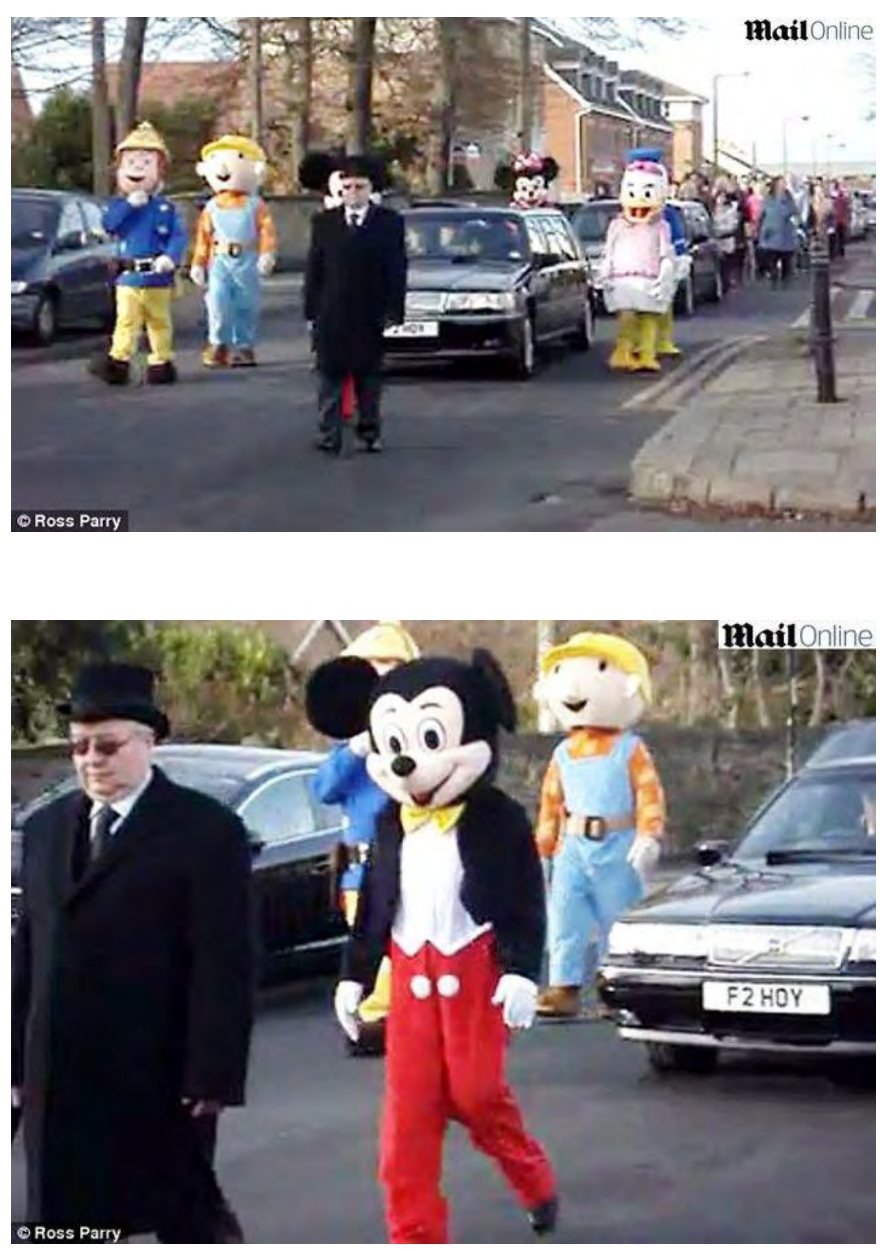

${ }^{15} \mathrm{http} /$ / virgula.uol.com.br/ ver/ noticias/ inacreditavel/ 2012/ 02/ 06/ 293745-familia-organiza-funeralcom-personagens-da-disney-para-bebe\#2 


\section{O FiLME "Quero SER GRANDE"}

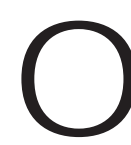

Filme "Quero ser Grande", de certo modo também estabelece uma relação de estranhamento parecida com 0 exemplo anterior: o filme, bastante simplório e feito para crianças nos anos 1988, apresenta uma história banal de um pequeno garoto de 13 anos que deseja ser grande e tem seu pedido alcançado. Ao conseguir que seu desejo se cumpra, precisa sobreviver e desempenhar papéis contidos na vida adulta: ele precisa arrumar uma casa, um emprego e maneiras de se sustentar como uma pessoa adulta qualquer.

No corpo de um homem, o menino lida com as situações do mundo real de modo bastante "idealizado" e "inocente", o que dá sentido a narrativa da comédia, que apresenta situações que passam por um grande "estranhamento" ao mostrar um adulto se comportando como uma criança e vice-versa. Ainda que a história seja bastante didática, creio que seja interessante pensar sobre esses aspectos do filme dando ênfase em algumas passagens e cenas que mostram claramente a relação de caos entre o universo da realidade e da ficção. Aqui no entanto, apenas apresento os exemplos, mas irei aprofundar algumas dessas passagens no capítulo sobre a Infância e sua importância para compreender este trabalho plástico ${ }^{16}$.

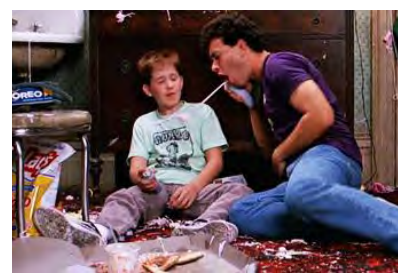

${ }^{16}$ No cap. sobre Infantilização, pretendo desenvolver uma análise a cerca da leitura do artigo "A síndrome dos KDULTS", do sociólogo Frank Furedi, que a analisa a crescente infantilização da cultura 


\subsection{Teatralidade}

"Representamos tanto na vida que, para fazer teatro, bastaria cessar a representação." Jerzy Grotowski.

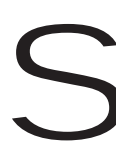

egundo Josette Feral em seu livro "Sobre Teatralidade" ${ }^{4}$ a condição que define a Teatralidade é a criação de um "espaço outro", dentro do universo do real, em que a ficção possa surgir. Essa condição é própria do teatro, mas ao mesmo tempo, não é somente o teatro o único produtor de efeito de tal Teatralidade. Para Féral, a Teatralidade presente na peça teatral repousa sobre 0 ator movido por um instinto que 0 instiga a transformar 0 real que 0 circunda. 0 que se pode deduzir que 0 conceito de Teatralidade está intimamente ligado a sujeito "a ficção e a realidade".

Ao associar as estruturas de representação do sujeito que se coloca no papel de personagem quando busca elementos estéticos presentes na atuação de sua vida cotidiana idealizada, refiro-me ao teatro dramático e a necessidade que o sujeito tem de dramatizar a sua própria história de vida.

Para o senso comum, o drama significa um acontecimento comovente ou uma situação de grande intensidade emocional. $\mathrm{O}$ sentido encontrado nessa definição me interessa muito para construir o trabalho plástico, porém não posso deixar de observar que a definição literária e teatral do drama também fortalece meu pensamento:

Como se sabe, na Grécia Antiga o gênero dramático nasceu dos rituais religiosos. Os homens através destes rituais realizavam a celebração de grandes festas, procissões, espetáculos públicos, cantavam e dançavam, usavam máscaras, roupas especiais e tochas. Estes

${ }^{4}$ Féral, J. A cerca de la Teatralidad. Caderno de Teatro XXI. Buenos Aires. Nueva Geracion, 2003. 
rituais possibilitavam ao homem, através da imitação e representação, o contato com o êxtase divino.

Desse modo, a dramatização, como imitação por meio de personagens em ação, só adquire vida se corporificada em encenação. A encenação dramática é uma criação híbrida, uma síntese de recursos diversos, envolvendo atores, encenadores, cenário, música, figurino, coreografia, etc. A Teatralidade, assim como a dramatização, trás uma idéia direta de corpo, astúcia, jogo, ficção e falseamento.

Assim, o conceito de Teatralidade também recebe novas concepções, passando a abarcar questões que excedam ao texto dramático e dizem respeito ao que é teatral, no sentido da ação e não apenas do texto dramatúrgico. Os textos de teóricos que abordam a questão da Teatralidade vão se separando da noção de texto para repousar sobre a representação em si. Esse conceito se amplia o suficiente para despertar o estudo em diferentes disciplinas, podendo também ser utilizado em vários campos artísticos e não artísticos. Portanto, o conceito de Teatralidade pode ser utilizado de modo bastante amplo, assim como a definição de teatro na atualidade.

Segundo Ana Lúcia Pardo, a Teatralidade é uma expressão que deve ser entendida como algo que acontece para além do mundo do espetáculo. A Teatralidade é algo que reflete sobre o humano e sobre suas possibilidades de reinventar, de se transformar, se tornar múltiplo e desempenhar diferentes papéis que vão além do palco e em direção à sociedade.

Há uma vasta definição para a palavra Teatralidade, no "Dicionário de Teatro" da autora Patricia Paves, entre os diferentes significados, a autora afirma que este conceito está relacionado com algo de místico, idealista, etnocentrista e excessivamente ge nérico. Para a autora, o termo é tão complexo, que assume formas e expressões variantes quanto o próprio ser humano, uma vez que lhe é intrínseco. 
Como já disse em outros momentos da dissertação, um teórico que desenvolve uma versão para o conceito de Teatralidade é 0 sociólogo Erving Goffman, que escreve em seu principal livro, "A representação do eu na vida cotidiana", sobre a funcionalidade da Teatralidade na vida dos homens comuns. Ainda que essa abordagem não contenha em sua totalidade tudo o que desejo ser, a Teatralidade que busco evidenciar em minhas fotografias, acredito que seja importante falar um pouco sobre essa maneira de pensar a Teatralidade, que de certo modo, definiu muitas idéias para este trabalho e possibilitou com que eu definisse o título da dissertação.

Segundo Goffman, a Teatralidade e a representação são assuntos inerentes ao homem, extrapolam a delimitação do espaço cênico (local mais comum e que estamos acostumados a associar 0 termo) e existem nos espaços cotidianos da vida comum. Para ele, a Teatralidade se funde ao homem e incorpora-se a ele, de modo que se torna complexa a separação entre o que é o individuo e 0 que lhe é externo.

$\mathrm{O}$ autor estudou profundamente 0 comportamento dos indivíduos em diversas regiões e comunidades e passou a usar o conceito da expressão teatral como meio processual para pensar sobre o comportamento humano em suas diferentes situações sociais e 0 modo pelo qual ele aparece para os outros homens. Para Goffman, nós desempenhamos diferentes papéis, criamos personagens ao nos posicionar diante dos outros homens como meio de sobrevivência, aparência e manutenção de nossas obrigações da vida cotidiana:

"Não é provavelmente um mero acidente histórico que a palavra "pessoa", em sua acepção primeira, queira dizer máscara. Mas, antes, o reconhecimento do fato de que todo homem está sempre e em todo lugar, mais ou menos, conscientemente, representando um papel (...) São nesses papéis que nos conhecemos uns aos outros; são nesses papéis que

\footnotetext{
${ }^{6}$ Fragilidade. Jean Claude Carrier 2007. pag. 13.
} 
nos conhecemos a nós mesmos. Em certo sentido, e na medida que esta máscara representa a concepção que formamos de nós mesmos - o papel que nos esforçamos por chegar a viver-, esta máscara é o nosso mais verdadeiro eu, aquilo que gostaríamos de ser. Ao final a concepção que temos de nosso papel torna-se uma segunda natureza e parte integral de nossa personalidade. Entramos no mundo como indivíduos, adquirimos um caráter e nos tornamos pessoas". ${ }^{5}$

Para além de observar os conceitos de Teatralidade, e entender que todas as definições contribuíram para eu encontrar qual seria o tipo de Teatralidade que de fato me interessaria para construir o trabalho, resolvi denominar pessoalmente como Teatralidade Extravagante o conceito que desenvolvi como assunto principal para produzir os trabalhos plásticos.

Seria assim, a Teatralidade Extravagante, aquela que para além de uma representação funcional de sobrevivência do ser diante dos papéis encenados, principalmente um meio de ficcionalização, idealização, e distanciamento da realidade comum.

Desse modo, é importante dizer, que sustento um entendimento penoso ao pensar a condição da realidade e estou colocando nas mãos do universo imaginário, a resposta como fuga para esta situação. Pode parecer ingênuo este tipo de posicionamento, mas neste momento a pesquisa é pautada sobre muitos maniquésmos intencionais: realidade x ficção, belo x feio, Bom x Mal, Teatral x Real, etc. Talvez em um novo momento do projeto, mas a frente, conseguirei tornar essas relações menos conflitantes e mais sinuosas.

Para reafirmar os motivos pelos quais os sujeitos Teatralizam de modo Extravagante, utilizo um conceito de um segundo teórico, filósofo e roteirista, chamado Jean Claude Carrièr, que aborda em seu livro "Fragilidade", o conceito da Fragilidade humana, como se metaforicamente, cada indivíduo tivesse dentro de si 
uma "essência de vidro", um espaço humano de "vulnerabilidade" que tornaria todos os seres igualáveis. Para Carrièr, a impressão de solidez maciça que a aparência de um corpo pode dar, não nos oferece nenhuma garantia de duração, porém nossa imperfeição é complexa para assumirmos como simples fraqueza e por isso a dissimulamos através da representação de papéis (através de uma suposta Teatralidade da vida cotidiana).

Os outros, que contudo são exatamente como nós, não devem a nosso olhar, suspeitar do que somos e nós nos escondemos dos olhos

dos outros. Como o próprio Jean Claude Carrièr diz em seu livro "Fragilidade":

“Talvez a história das civilizações não seja se não uma série de tentativas, cada vez mais refinadas, de mascarar nosso verdadeiro rosto. De início, para escondê-los de nós mesmos; depois, dos que poderiam alimentar a vontade de nos atacar, de nos sujeitar, bem como a idéia absurda de nos decifrar, de nos revelar". ${ }^{6}$

A consciência da fragilidade apontada por Carrièr evidencia uma certa melancolia que também proponho pensar na construção teórica e prática da dissertação. 0 cenário, os personagens, a memória da infância, a idealização contida em um imaginário, "infelizmente" ou "felizmente" não dão conta de ficcionalizar a realidade de modo a aniquilá-la, pois o que é real, sólido, vivo e contínuo muitas vezes se sobrepõe: os balões murcham, o dia após a festa existe e acontece, os restos e desgastados registros de infiltrações das paredes das casas aparecem com o passar do tempo e os confetes, por exemplo, são pisoteados no amanhecer após o carnaval.

Dessa constatação que acontece completamente imposta pela realidade da vida, sentimos um ar breve de melancolia, vazio, um sentimento de desamparo e desapontamento diante da impo- 
tência de existir e não poder controlar tudo que gostaríamos de ter controlado, feito e que infelizmente, não conseguimos realizar.

A grande maioria de minhas fotografias apresentam uma vontade de construção pautada na intenção de negar a realidade, quando por exemplo, apresento muitos objetos e cores vibrantes, porém na mesma imagem também nota-se uma visão palpável da realidade, pois apesar dessa intenção, há também a noção de ruína, melancolia, necessidade de felicidade encenada através do objeto da encenação. E isso tudo acontece de modo sincrônico, tudo junto ao mesmo tempo e na mesma foto.

Desse modo, se em um primeiro momento eu tento como artista camuflar a realidade através dessa intenção de representação e Teatralidade, também me dou conta de uma "fragilidade" que é imposta através do desapontamento diante do saber de que não é possível idealizar tudo, pois apresento em um segundo momento alguns resquícios de que esta perfeição não existirá.

Assim, aponto no trabalho as relações entre esses objetos de encenação vindos de um modo docemente imaginário e o encontro com a solidez da realidade, gerando desse modo um terceiro espaço de reflexão, pois nesse momento meu objetivo é criar visualmente proposições dedicadas a pensar esses momentos de embate que existem entre Realidade x Ficção ao Teatralizarmos nossa realidade. Algumas vezes, esses opostos apresentam-se em conflito na imagem fotográfica e em outros momentos, quando se somam e geram equilíbrios, passam a criar um terceiro espaço curioso e reconhecível, apesar de não se saber exatamente o que se vê.

Na primeira situação, uma espécie de ruína surge como fruto deste atrito, pois noto, ainda que as tentativas Teatrais exponham sua presença sobre a vida, a realidade muitas vezes se sobrepõe e a satisfação plena da nossa imaginação pode ser interrompida. Na segunda situação, os elementos ainda que opostos se somam, potencializando as diferenças de cada um e gerando um terceiro universo na imagem, nem tão real e nem tão idealizado.

Vale lembrar que atualmente o mundo se tornou uma gran- 
de platéia constante, diante de todos os fatos que ocorreram na vida do homem e os meios de comunicação inclusive e principalmente a internet potencializarem essa Teatralidade.

Hoje todo tipo de informação se tornou uma grande platéia em que todos podem fazer o seu espetáculo particular. Assim, todos viraram ao mesmo tempo que palco, também platéia e, como uma espécie de doutrina, tudo é teatralizado.

Porém, é importante frisar que para este trabalho, não pretendo criticar o impacto das mídias e da tecnologia na vida contemporânea, como também sustentar a idéia de que a cultura contemporânea é fruto de uma realidade construída. Ao contrário, defendo a Teatralidade como uma necessidade de sobrevivência e fuga humana e nos trabalhos que apresentarei adiante, ora defendo essa Teatralização, ora apresento contrastes dessa Teatralização com a Realidade, porém a questão política e social não é um foco intencional, ainda que alguns trabalhos toquem consequentemente esses assuntos. 


\subsection{INFÂNCIA}

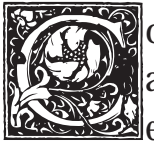

omo disse na introdução, estabelecer uma relação com a infância ao pensar este trabalho é fundamental, já que grafia, como ponto de tensão entre Realidade e Ficção. O desenvolvimento do papel da infância no trabalho plástico, apresentado, entra aqui de duas maneiras muito claras: primeiro, pela maneira formal, através da apropriação estética de objetos da infância e se gundo, pelo modo conceitual, ao pensar a infância como momento da vida oposto e "mais confortável" do que a vida adulta, reforçando assim a idéia de separação entre um momento de fantasia $\mathrm{x}$ um momento de encontro com a realidade.

A seguir, apresento brevemente, cada um desses dois aspectos que me levaram durante toda a pesquisa, a pensar intencionalmente e assumir a infância como um fator que acontece e se repete praticamente em todos os meus trabalhos. Ainda que a infância possa ser vista em meus trabalhos como algo limitador, viciante ou repetitivo, é importante deixar claro que nesse momento isso de fato acontece e é intencional. Não se trata de conceber a vida cotidiana de modo infantilizado e sim me apropriar do universo infantil como um ponto específico que neste momento da pesquisa, contribui como uma, entre muitas maneiras de pensar a questão da Teatralidade da vida cotidiana.

Primeiramente, analisar formas visuais que caminham em um plano do universo infantil, se tornou um recurso estético para 
a construção dos trabalhos em Poéticas Visuais que desenvolvi. Os objetos e ações ficcionais próprios da infância sempre apareceram nos trabalhos de duas maneiras principais: algumas vezes como ação idealizada na infância e realizada, ou almejada posteriormente na vida adulta (como já disse acima, por exemplo, a encenação e concretização da cerimônia matrimonial e suas promessas de felicidade, muito conhecidas por nós, nos finais dos contos de fadas). E outras vezes, e na maioria das fotografias encenadas, o objeto da infância aparece como presença direta em imagens de brinquedos, objetos, fantasias, parques e festas que estão todos misturados na nossa vida cotidiana e são próprios da criança, sem projeções futuras.

Em um segundo momento, para além de optar pelo uso do objeto infantil pelas suas cores e vibrações berrantes, que proporcionam uma facilidade estética na construção das fotografias, há também a questão da definição do motivo pelo qual utilizo os objetos da infância e não os da vida adulta. Mais uma vez, reafirmo que a apropriação do universo infantil vem como oposição ao mundo adulto.

Entendo desse modo, a realidade como algo penoso e duro e a infância como fase do aconchego da casa, proteção, conforto e acolhimento. Para explicar melhor esta minha forma particular de observar a realidade, cito Frank Furedi, sociólogo da Universidade de Kent no Reino Unido, que desenvolveu uma pesquisa para entender o motivo por que hoje muitos adultos se comportam como crianças.

Para Frank, que denomina esta tendência (adultos infantilizados) de síndrome chamada "Kidults", o senso de desespero que assombra a identidade adulta, ajuda a explicar porque a cultura contemporânea tem dificuldade em traçar uma linha divisória entre a infância e a idade adulta. Para ele, a infantilização é idealizada pela simples razão que sentimos desesperança e dor ao pensarmos em viver a vida adulta e ter que enfrentar uma penosa realidade. Assim, a depreciação da condição adulta (este entendimento 
pessimista da vida adulta pelo qual eu também assumo em meus projetos plásticos), é resultado das dificuldades que nossa cultura tem em afirmar os ideais normalmente associados a essa etapa na vida das pessoas.

Para reforçar esse modelo na prática, Frank entrevistou alguns alunos e percebeu que de fato muitos se prendem na infância como modo de se sentirem mais seguros e confortáveis:

“...John Russel de 28 anos, advogado bem pago, que dizia não se interessar em fazer "coisas de adultos", adora seu playstation e gasta uma parte considerável de sua renda com brinquedos de alta tecnologia. Já Fred Simons e Oliver Bailer, ambos corretores de imóveis no final da casa dos 20 anos, jogam Nintendo e se gabam de não ter mudado muito desde a época do colégio. A designer de 27 anos Helen Timerman me mostra sua coleção de brinquedos de pelúcia com muito orgulho. Ela adora abraçá-los e acha que seus bichinhos, dispostos ordenadamente em seu quarto, lhe proporcionam uma zona de segurança...."

Para descrever essa tendência, dois publicitários americanos, Becky Ebenkamp e Jeff O diorne, desenvolveram o termo "Pe terpandemônios" para designar as pessoas que na casa dos 20 e dos 30 anos buscam produtos do universo infantil como meio de obter a sensação de serem reconfortadas. Elas querem experiências sensórias que lhes tragam de volta uma fase da vida mais inocente e mais feliz: a infância.

Assim como pensam essas pessoas, em minha pesquisa, faço o exercício de me aproximar desses pensamentos ao chamar a atenção para observar a infância de modo conceitual como espaço do conforto que "nega" a realidade. O modo pelo qual me utilizo é a apropriação de objetos de festas, brinquedos, cores, em muitas situações, que nos apresentam um forte senso de fantasia. Entretanto, é importante repetir que a construção na fotografia encenada 
sempre é gerada a partir de um diálogo/ embate entre fantasia e re alidade, consequentemente não apresento apenas a infância, e sim, a relação entre infância e vida adulta. Assim, em minhas imagens, a situação da infância não é sempre tão confortável.

Como disse, em algumas imagens, ficção $\mathrm{x}$ realidade se somam, em outras, há uma anulação e, em outras, criam-se um terceiro espaço de vago reconhecimento e assimilação, como se nos reconhecêssemos diante de algo que nunca vimos. Essa sensação de estranhamento entre ficção e realidade é pautada por um sentimento de desapontamento e melancolia diante de nossa necessidade de idealizar a realidade e perceber que nem sempre conseguimos 0 que desejamos. 


\subsection{Fotografia: \\ Processo de EncenaÇão e Documentação}

M

eu objetivo ao me propor escrever este texto é pensar sobre procedimentos do uso dos instrumentos e materiais para a realização da produção de meu trabalho. Penso que seja importante neste momento descolar a pesquisa conceitual da produção prática e observar apenas quais são as estratégias que venho utilizando para construir os trabalhos.

A prática do trabalho do artista, na minha opinião, é dividida em dois momentos: as idéias, que o faz refletir sobre seu tema de pesquisa e quais são suas referências teóricas e a realização prática desse pensamento através da produção.

Meu intuito ao escrever este pequeno capítulo é criar uma oportunidade para observar através do discurso da "linguagem", um modo de formalizar e pensar externamente a minha maneira de proceder com o trabalho prático. Os próprios livros definem os diferentes tipos de uso de produção: a observação, construção, apropriação, encenação, subtração e a colagem são meios de entender uma prática. A fotografia como arte contemporânea em sua divisão, na minha opinião, é o melhor exemplo disso ao agrupar fotógrafos que tem a mesma base em termos de método de trabalho. Exemplos são: os fotógrafos que performatizam para a câmera, as fotografias de narrativas históricas, a fotografia psicológica, a fotografia documental, o fotojornalismo, a fotografia encenada, entre muitos outros tipos. 
Como meu trabalho plástico, em função de minhas necessidades práticas, em sua grande maioria, apresenta-se através do uso da fotografia, me proponho neste momento falar somente da imagem fotográfica como suporte.

A começar pela função prática, a fotografia como instrumento que possibilita a captação, fixação, pausa, segurança, aprisionamento, documentação de algo que passa pelo mundo externo, é um meio crucial para eu conseguir entender a idéia de que, se desejo, como assunto do trabalho, mostrar parte de uma observação que está presente em meu cotidiano, necessito, para que isso se concretize, do uso de um instrumento que capte o estímulo externo.

Obviamente, que pode soar ingênuo e simplista o pensamento, pois posso me valer da apropriação de centenas de elementos que estão fora de mim, para construir a reflexão em arte. No entanto, é importante ressaltar que a grande maioria de todos os trabalhos realizados por mim, até hoje, se valeram da foto como material final. Vale dizer, que muitos trabalhos aconteceram em parte como apropriação, escultura e instalação, mas que na maioria deles, somente após registrados através da fotografia, concluíram-se.

É natural pensar a fotografia como o instrumento que capta a realidade (no caso a fotografia documental/fotografia jornalística, entre outros gêneros) como também é próprio pensar a fotografia como meio de construção de ficção (a fotografia montada); encenada; fingida; imitada; ilusória; falseada; etc.) como dois pólos quase opostos, que porém se completam. Mesmo que aparentemente possamos ver uma linha de divisão entre os dois termos praticamente opostos, é através dessa dualidade que mantemos a consciência de que nem tudo que está na fotografia documental é digno de crença de realidade, assim como também nem tudo que está na foto encenada seja apenas simulação.

Essa mistura que a fotografia permite, ainda que olhando somente sob um mínimo ponto de vista dentre suas amplas características, dialogam com a necessidade que tenho de observar na vida cotidiana os instintos de representação, encenação e idealização da 
vida real.

Tornar esse incômodo íntimo, uma realização mais gené rica que contribua como arte para tencionar estratégias que possibilitem que o outro também seja contaminado por essa percepção, é o meu objetivo como artista e a fotografia neste aspecto tem sido fundamental para esse alcance. Desse modo, julgo importante analisar os procedimentos formais utilizados na manipulação da fotografia para pensar o que eu tenho feito.

A seguir, apresento três classificações pessoais, que atribuí a uma divisão dos trabalhos. Essa separação se assemelha um pouco ao que já falei no Capítulo sobre meus trabalhos anteriores, no início da dissertação, no entanto, o foco agora é pensar apenas a estratégia de manipulação da fotografia.

A Fotografia Encenada ou a fotografia de quadros/quadros-vivos1 como também pode ser conhecida, é a fotografia pela qual a narrativa está contida em uma única tomada. Nela podese notar que a narrativa pictórica se concentra em uma imagem e a fotografia conta toda uma história. A Fotografia como campo de manifestação do real estaria isenta de criatividade e imaginação, pois a velha idéia de que a foto seria a representação técnica da realidade não cabe para este tipo de aspecto que surge com artistas que se tornaram uma referência para meu trabalho, como Cindy Sherman, Jeff Wal e Gregory Crewdson, entre uma infinidade de muitos outros.

Como primeira classificação, consigo visualizar que nas minhas duas primeiras séries de trabalhos "Na Companhia dos Objetos" e "A Casa em Festa", o processo pelo qual eu articulava a fotografia era próprio da construção da cena para a câmera fotográfica. Inicialmente em função de uma idéia (conceito do trabalho) de pensar a minha relação com os objetos da casa, passei a me apropriar dos espaços fixos que a caracterizam casa e fotografá-los não de forma a documentá-los em sua realidade de existência, mas com intuito de modificá-los tornando-os ficcionais.

0 termo ficcionalizar entra neste trabalho como meio de 
compreender uma articulação prática para a foto, pois antes de fotografar eu realizava uma espécie de "instalação" em que nada mais se encontrava como antes estava: eu acumulava todos os objetos dos espaços e ao empilhá-los, formava uma grande estampa chapada que descaracterizava totalmente 0 ambiente. A casa ainda que lembrada pelo excesso de objetos domésticos, sumia na cena construída e tornava-se mais cenário, tornando-se espaço de simulação da realidade em que eu "ficcionalizava" minha própria história.

Para entender a classificação da foto encenada como processo de construção que valida o uso da fotografia como único meio para realizar estes dois trabalhos, dois pontos são principais para pensar: o primeiro é que apesar de existir uma instalação antes da realização da fotografia, somente a fotografia poderia captar a estética da superfície plana desejada. 0 segundo ponto era a minha presença imóvel na cena, o auto-retrato que surge não como intenção, mas como necessidade, pois seria impossível encenar ao vivo, pois eu nunca poderia me confundir com um objeto, idéia que eu desejava e que na foto era possível potencializar.

Mesmo assim, as imagens foram compostas com objetos que de certo modo "documentavam" os objetos e uma casa específica. Assim, como um documentário por exemplo, em que se cria uma espécie de encenação com fatos reais. Por isso, nada é completamente fechado, e o critério para chamar de foto encenada é também variável.

É importante ressaltar, que há diferentes tipos de fotografias encenadas e que cada artista desenvolve sua própria maneira em detrimento da coerência com a reflexão plástica. Pensar na re ação do público ao observar uma obra, para além da intenção do artista, é interessante para "confirmar" classificações nesses casos. Ainda que, isso não seja necessário em um trabalho de arte, acho importante pensar sobre a reação do público ao olhar para obra, pois isso me ajuda categorizar os processos, por mais estranho que 
isso possa parecer.

Como segunda classificação, consigo observar algumas sé ries de trabalhos que vieram na seqüência, no caso foram séries em que eu me deslocava do espaço de minha casa e entrava em ambientes que já apresentam uma outra própria história. Os espaços eram interferidos, porém respeitados, pois muito do que já estava ali em "realidade", apresentava-se na imagem da mesma forma que a parte construída ou sobreposta a ele.

Foram, por exemplo, as séries que realizei durante períodos em que trabalhei em residências artísticas, como "Sonhar com uma Casa na Casa", e "Gorlovka,1951". Seria assim, uma fotografia caracterizada pela construção sobreposta a uma imagem já dada, que eu arriscaria dizer documentada. O u seja, esta segunda classificação poderia ser a fotografia encenada sobreposta a uma documentação.

Neste caso, existe a necessidade de construção a partir da apropriação de um ambiente já existente com características próprias históricas, estéticas, sociais, etc. A imagem fotográfica não é construída do zero, ela parte de um fundo "real" quejá está presente e a partir dele pensa-se a construção que o ficcionaliza, de modo que ao fim esse espaço interferido passa a ser outro, ainda que fiel a si mesmo.

A idéia dessa classificação é que o processo de criação muda completamente, ainda que seja uma fotografia encenada, ela parte de um ambiente de uma apropriação de imagem que já havia no espaço e que não foi alterada, a não ser através da sobreposição e encaixe de alguns elementos que poderiam ou não estar ali. Este é o ponto em que uma foto dessa classificação carrega a dúvida sobre sua construção processual. Aceitar que estou partindo de um ambiente real para a criação e direcionar minha intenção de construção, seja por motivos conceituais ou estéticos, a partir dessa paisagem inicial, possibilita ousar em dizer que há algo de "documental" neste processo.

Uma terceira classificação seria a fotografia propriamente 
documental que englobaria, por exemplo, o trabalho "O Caminho que percorri até te encontrar". Uma instalação fotográfica realizada em Paris através de uma catalogação de todos os carrosséis que encontrei na cidade dentro de um período de tempo. Cada catalogação era composta por uma fotografia documental que registrava um carrossel encontrado em realidade na cidade de Paris.

Ainda que eu pense nessa classificação como propriamente documental e sem muitas mesclas ou complexidades, é importante pensar que apesar de a fotografia para o trabalho ter sido registrada do real, a construção processual da instalação como um todo manipulou a imagem para que ainda que fiel 'a realidade, ela pudesse se tornar ficcional. Além disso, é possível notar que neste processo há uma inversão, pois o processo documental é que passa a revelar o encenado e passamos a perceber o quanto a fantasia se embrenhou na realidade.

Desse modo, criar um mapa de Paris e desconfigurá-lo em sua utilidade funcional de localização de espaços emergenciais e torná-lo quase "banal" ao apontar apenas para direções de um brinquedo de parque, o tornava fora do comum, idealizado, mentiroso ou ficcional. Por outro ponto, também as imagens perdiam sua consistência documental a partir do momento em que compunham um mapa inútil e sem garantia de efetivas relações com a geografia. Por fim, o próprio brinquedo que em Paris é itinerante, tornava a fotografia documental extremamente ficcional, pois talvez o que fora registrado ali, em realidade, hoje de fato não exista mais e seja mera invenção.

Outro exemplo seria o trabalho "Mickey's Daily Work" em que a instalação fotográfica existe como documentação de um dia de trabalho do personagem Mickey na Disney. A fotografia entra como mero registro de famílias e amigos posando junto do personagem Mickey.

Entretanto, o tema propõe pensar sobre uma nova articulação que transforma o meramente documental em ficcional, pois normalmente se tem uma única foto de sua família com o Mickey 
e não 400 imagens de famílias tiradas em um dia na Disney. 0 caráter documental se perde na medida que não tem o objetivo de registrar, guardar, fixar o momento, mas sim confundir, tornar inútil e anular pelo excesso a intenção da qualidade íntima de documentação do momento de memória da criança com seu personagem preferido.

Ainda pensando sobre isso, o tema que permite de fato de sestruturar a imagem do Mickey como modelo ideal, a que se quer encontrar, em seu excesso, banaliza o encontro que seria único e 0 torna genérico, massivo e real. A idéia entre realidade e ficção, ainda que através da fotografia inicialmente documental, é construída como encenação em seu conjunto ao propor através da montagem da instalação, uma montagem incomum ao uso daquela fotografia tamanho álbum. 


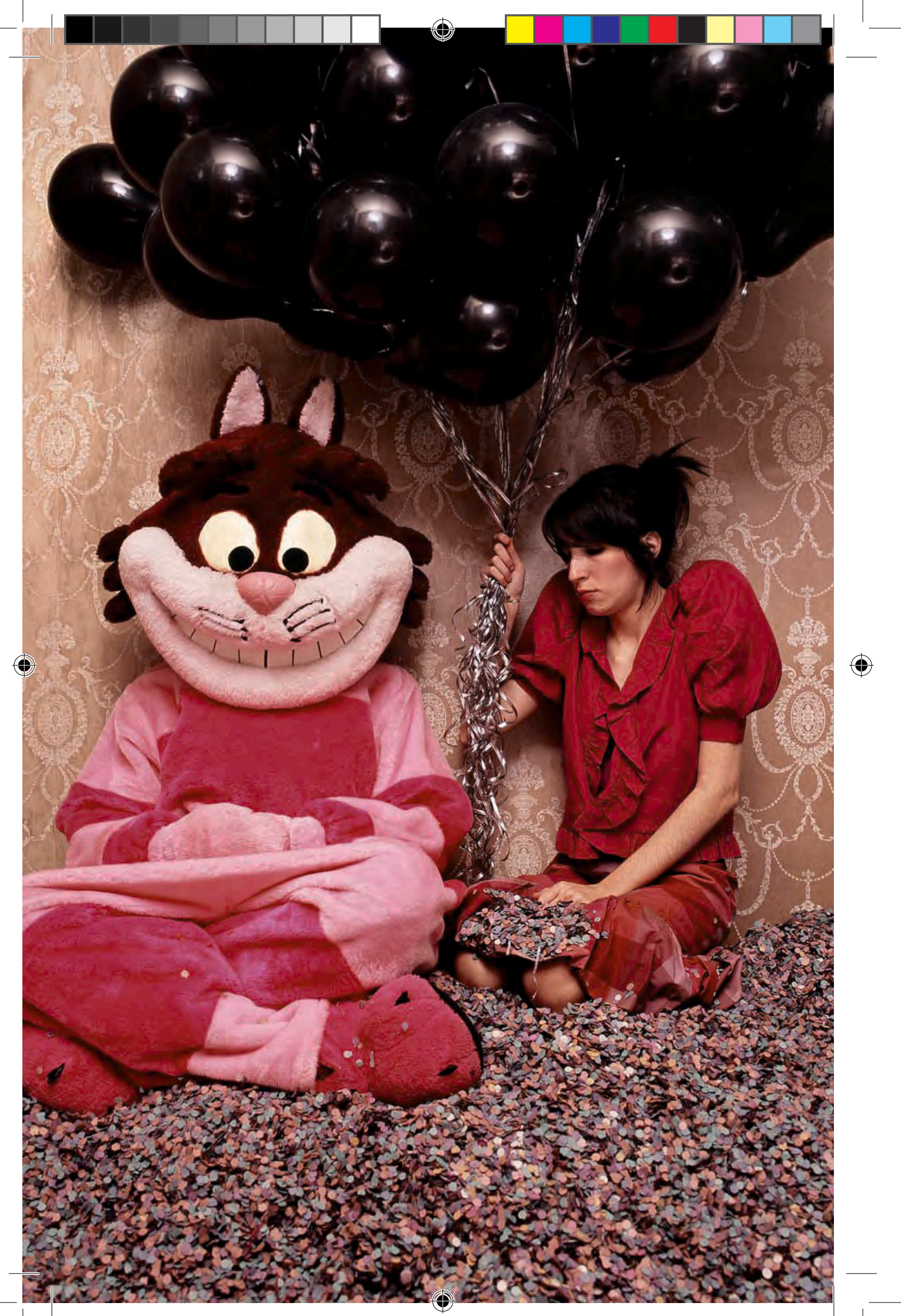




\subsection{FERRAMENTAS PARA CHEGAR AO PRODUTO FINAL}

este momento, irei me dedicar a narrar como funciona 0 meu processo de trabalho e quais são as ferramentas práticas necessárias para produzir a fotografia final.

Para isso, irei analisar três fotos específicas que foram realizadas em um mesmo dia, mostrando o "antes e o depois" com imagens e explicando o que foi necessário na prática para produzí -las. Acredito que seja importante pensar no procedimento real de produção e performatização como parte do processo de reflexão do trabalho. Entretanto, valem aqui algumas considerações que servem para todos os trabalhos.

Sempre houve preocupação em aproveitar tudo que já existia, desde que se adequasse ao pensamento inspirador. 0 mesmo aconteceu com o material a ser adquirido. Tudo foi comprado com bom senso: economia, sem prejudicar a produção da obra, preferivelmente em lugares especializados e de atacado, inclusive locados. Materiais não comercializados foram executados em ateliê.

Foram contratados profissionais: a) um assistente para produção e montagem das cenas e organização em geral; b) um fotógrafo especializado. c) amigos se propuseram voluntariamente a participar das cenas no momento da fotografia.

A série que, agora irei analisar se chama "A Casa em Festa" e foi realizada no ano de 2009. Como de costume, na época eu realizava as fotos na casa de minha mãe. A seguir, irei descrever em tópicos, como "passo a passo", a execução inicial até o final da obra: 


\section{Etapa 1: Pré-ProduÇão}

1. Definir o conceito da série, que era fotografar auto retratos em que eu me acumulava em objetos de festas dentro de uma casa cheia de memórias dos objetos.

2. Decidir escolher quais eram os lugares da casa de minha mãe em que eu faria o trabalho: Duas fotos seriam externas, no jardim (fotos com flores e balões no ar) e uma foto interna, na sala de jantar (a mesa principal com o bolo da festa).

3. Pensar que as três fotos poderiam ser produzidas em um mesmo dia, pois estavam na mesma casa em espaços próximos e eu pagaria apenas uma diária para 0 fotógrafo. 0 trabalho em geral duraria cerca de $2 \mathrm{hs}$ para cada clique, no total de 6 horas de trabalho.

4. Comprar os materiais necessários a construção da cena: balões de gás hélio; alugar um cilindro de gás hélio grande; comprar 60 balões em formato de bichos metalizados e mais 200 balões comuns; brinquedos e ornamentos de festa; flores naturais;alugar fantasia de mascotes de pelúcia; comprar finalmente filmes para a câmera fotográfica.

5. Produzir objetos de cena não comercializados, no ateliê: bolos e doces artificiais.

6. Concluir previamente com o material disponível tudo que for possível. No dia da fotografia, complementar a cena com todas as figuras e detalhes idealizados.

7. Avisar as pessoas amigas que se propuseram a usar as 
fantasias, marcando dia e hora, bem como o fotógrafo contratado. Obs.: $\mathrm{O}$ cenário é montando por mim, que dirijo a cena, delineio os espaços a serem fotografados e desenho o produto final. Cabe ao fotógrafo apenas o clique da imagem.

8. No dia da montagem:

- Fazer as fotos externas. Nota: escolher o melhor período do dia em função de fatores climáticos como: chuva, vento, frio, calor e sol.

- Pessoas Participantes: três voluntários, usando fantasias dos bichos mascotes, fotógrafo e seu assistente; um assistente de organização geral;mais um fotógrafo para o maiking off. (Fig.5).

\section{Primeira foto externa:}

- Materiais necessários: flores e balões (considerar a velocidade do vento); espelho pequeno (para a artista dessa cena posicionar-se corretamente); traje adequado; maquiagem para retoques. (Fig. 1); (Fig.6) e (Fig.10).

- Segunda foto externa:

- Acrescentar ao cenário da primeira foto, três pessoas vestidas de mascotes. (Fig.2);(Fig3);(Fig4) em lugar do tufo de balões de gás hélio.

\section{Foto Interna:}

- Materiais necessários: móveis (uma mesa grande);Toalha da mesa (arrojada em sua decoração); serviço de mesa (copos, pratos e talheres); bolos e doces artificial (artísticos); líquido coloridos em copos transparentes; canudinhos para sucos. Velas em profusão; extintor de incêndio; espelho e maquiagem. Muita luz artificiais e flash (como usados em Studio); mascotes. Balões, varais de bandeirolas e parabéns. (Fig. 7, 8, 9) e (Fig. 11). 


\section{Pós-PRoduÇÃo:}

\section{Primeiro Momento:}

. Desmontar; (o cenário)

- Classificar; (os objetos)

- Catalogar; (as caixas)

. Arquivar; (em espaço próprio no ateliê)

. Limpa; (o ambiente)

. Descartar; (material não reutilizável)

\section{SEGUNDO Momento:}

. Devolver materiais locados; (fantasias e outros objetos)

- Pagar pessoal contratado; (assistente, fotógrafo)

. Pagar materiais locados;

- Contabilizar gastos realizados

(gerar custo final de cada foto)

\section{TERCEIRo Momento:}

. Revelar e selecionar as imagens;

- Enviar para o scaneamento em alta definição;

. Escolher fotos finais a serem utilizadas;

\section{Quarto Momento:}

. Limpar digitalmente o scan;

. Fazer Photoshop;

(Nota: o uso do Photoshop, após a produção digital é utilizável em situações que não se consegue controlar a imagem no plano real). 
. Evitar que o material se torne artificial, por tanto, usar Photoshop o mínimo possível.

\section{Quinto Momento:}

. Definir:

a) O material de impressão; (metacrilato, papel brilho) na maioria das vezes.

b) $\mathrm{O}$ tamanho e o formato da foto.

- Imprimir o trabalho.

- Enviar o arquivo digital acabado para o laboratório fotográfico.

- Avaliar a prova. Autorizar suca confecção.

(Nota: Ampliar fotos para evidenciar detalhes de cada objeto).

. Encaminhar imagem aprovada à molduraria.

A seguir, imagens da pré produção e dos três trabalhos finalizados: 

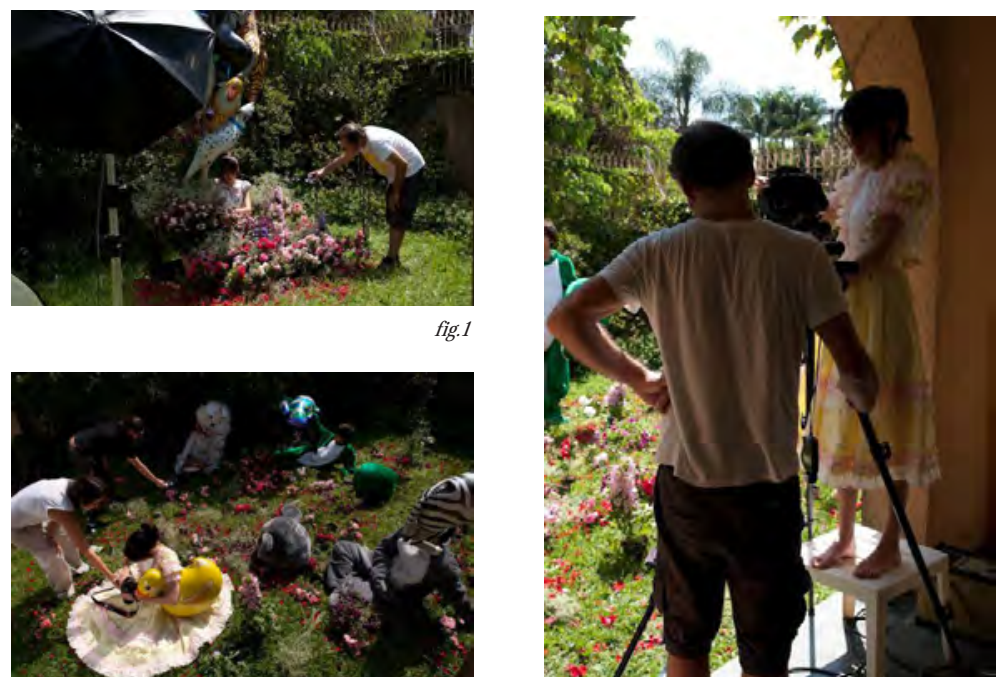

fig.2

fig.5
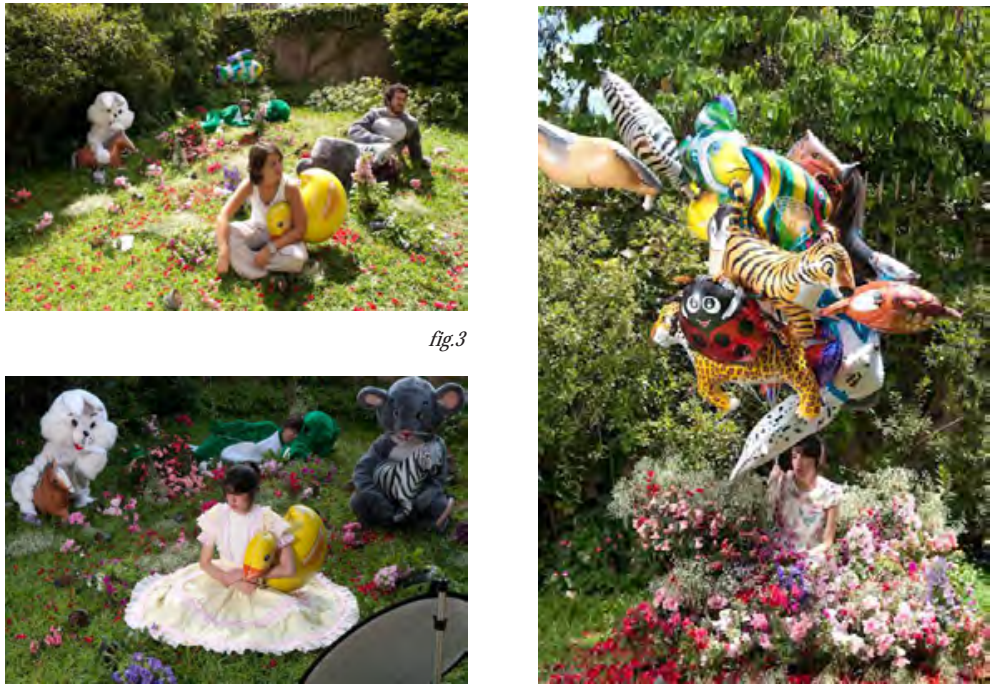

fig.4

fig.6

Nota: Foi difícil a entrada em cena da artista, sobre a mesa, considerando o volume de objetos e perigo de acidente. 
(

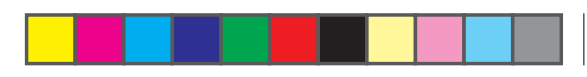

A TEATRALIDADE DA VIDA COTIDIANA

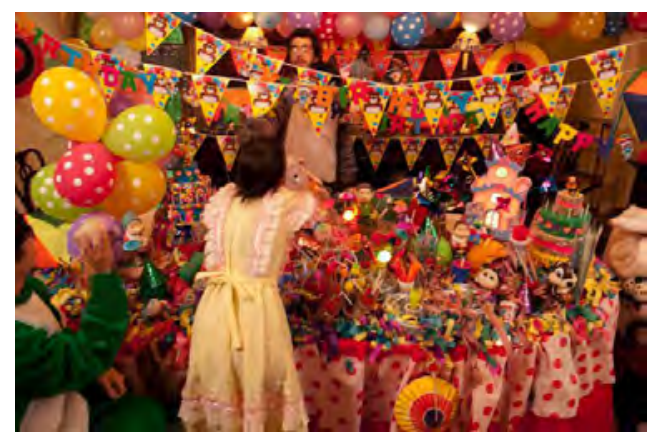

fig. 7

$\oplus$

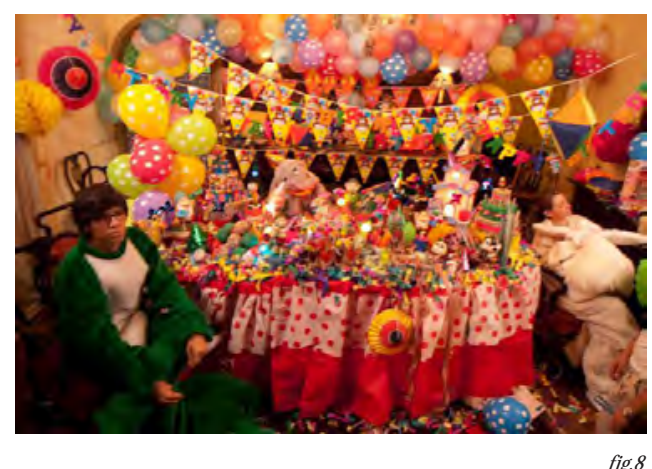

$\oplus$

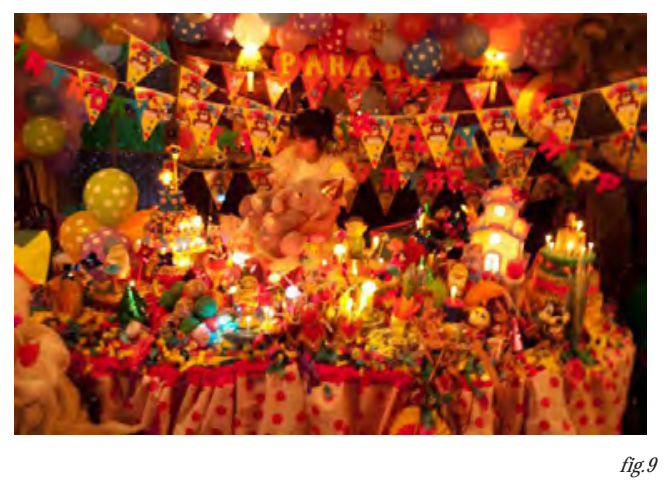


$\oplus$

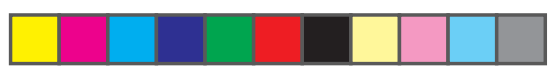

A TEATRALIDADE DA VIDA COTIDIANA

$\oplus$

RESUltado FinAL: 


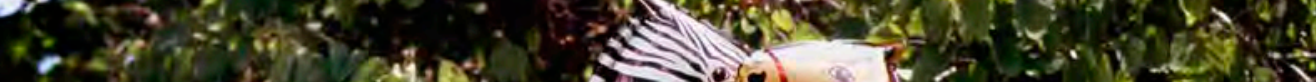

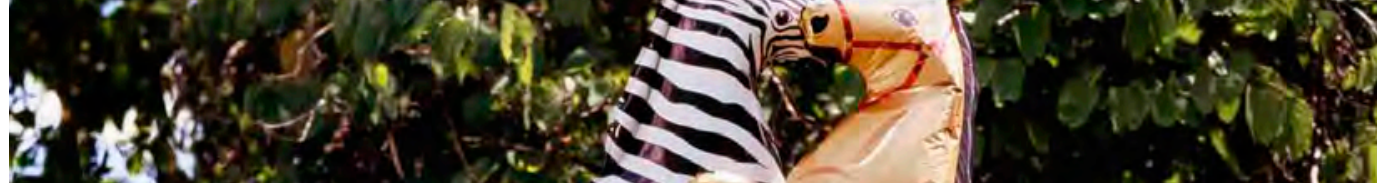
(1)

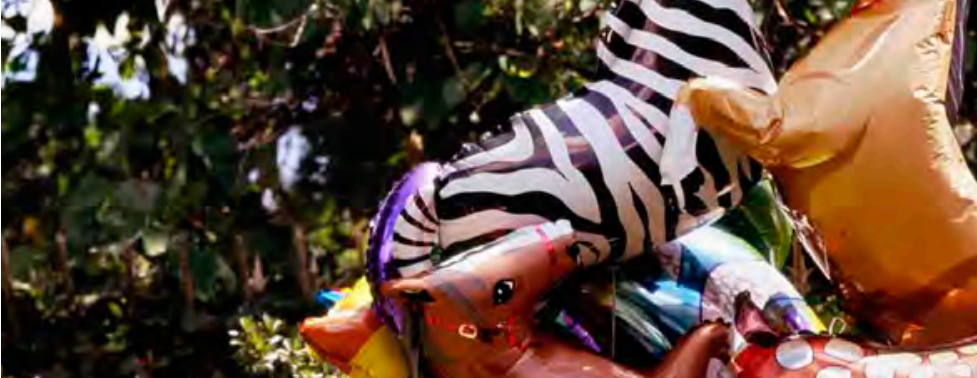

\section{Sis.} $\rightarrow$ trign

(x)

3.

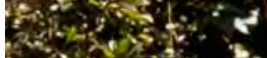

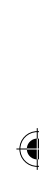

3.

$\oplus$

axis. 0 .

5xit

atis
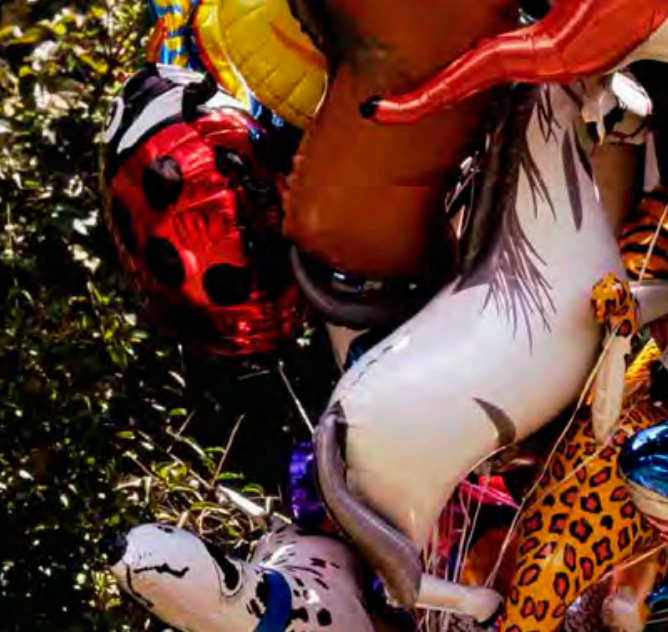

$\hat{k}^{2} \cdot \cdots$

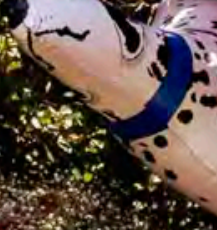

(3)
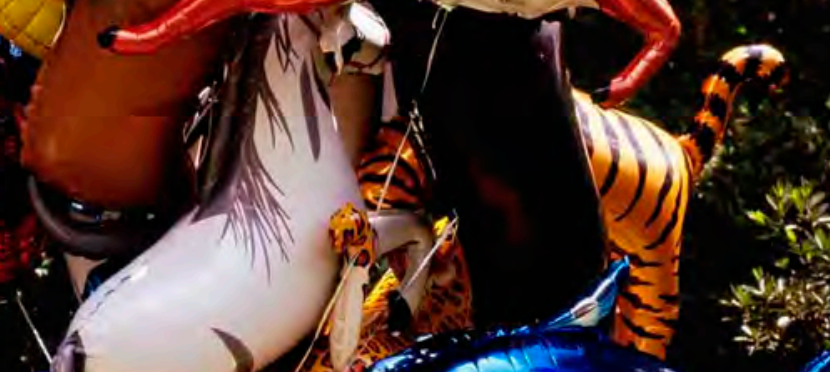

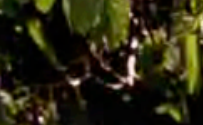

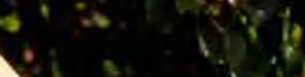

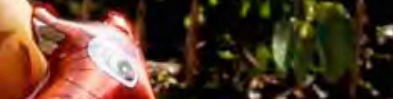

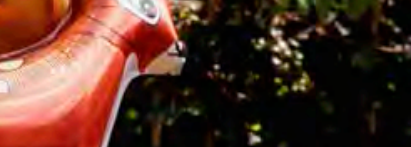




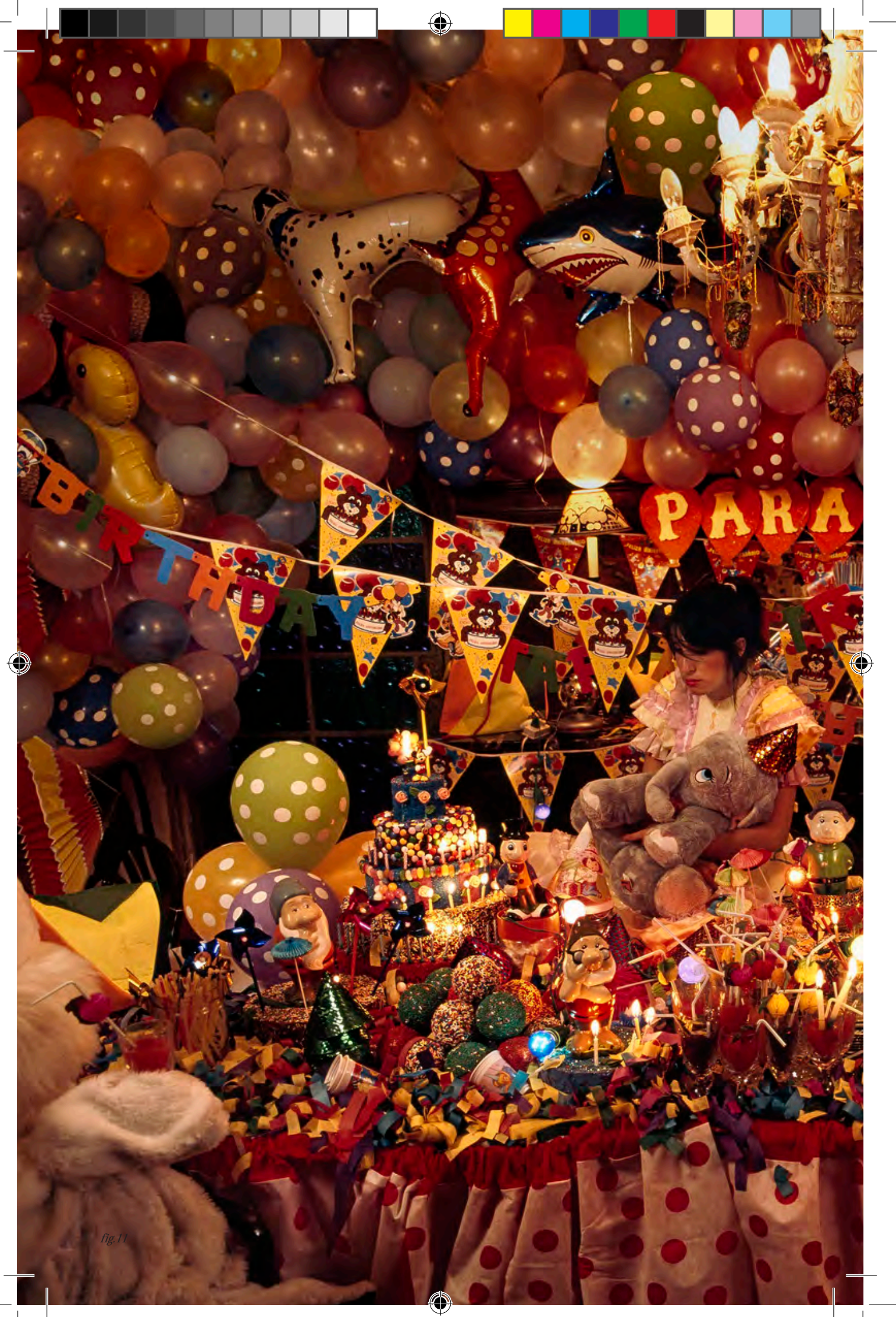




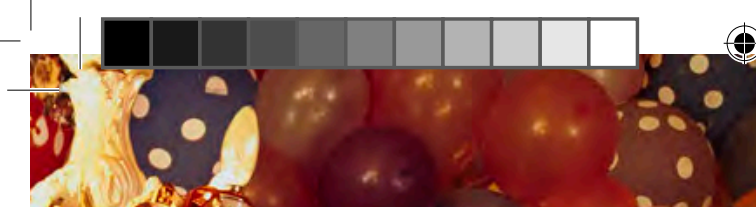

$14 x^{-1}$

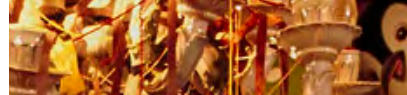

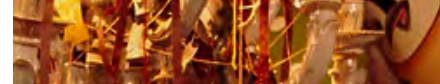

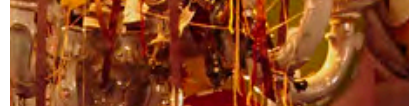

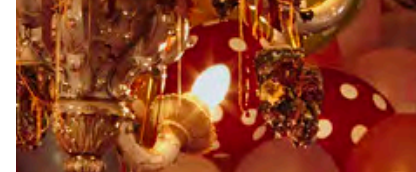
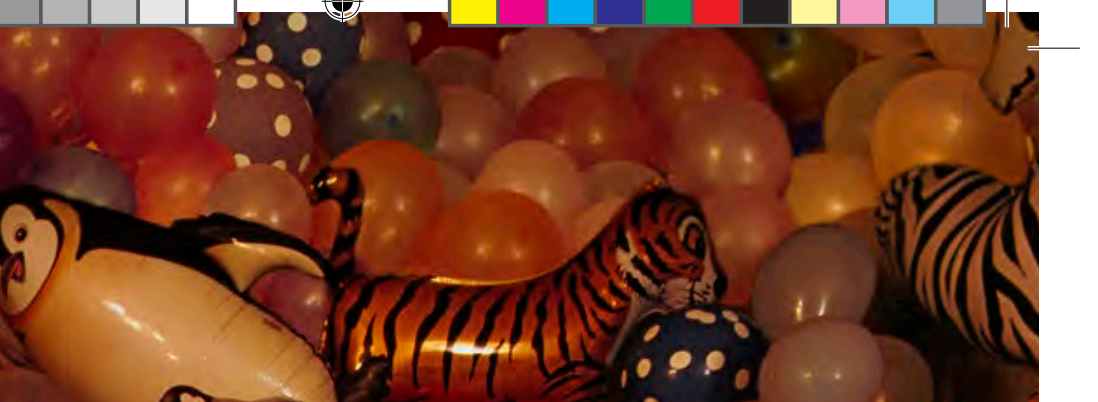

(3)

$\therefore \therefore$

$\because \because \cos ^{2}$

atis. 1,0

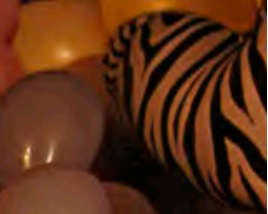

8

1 $\because \therefore$

(i) bis

$=\frac{1}{3}$

.

.

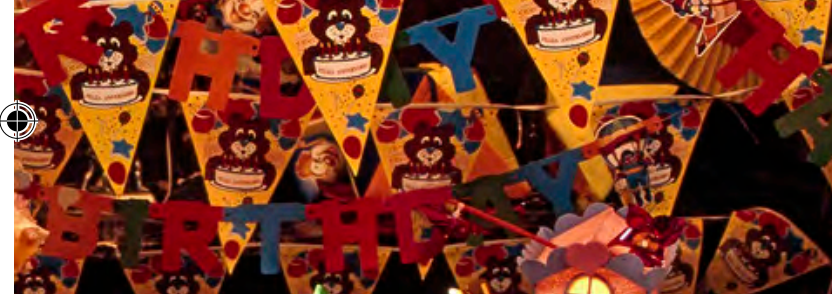

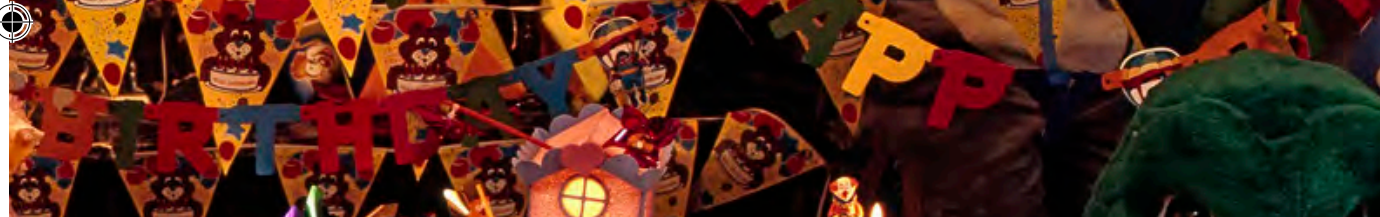

5 S.

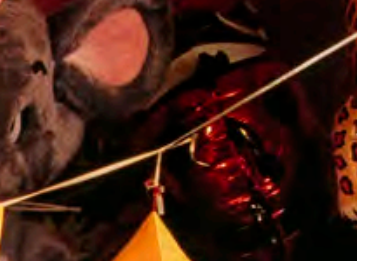

$\therefore$ (3)

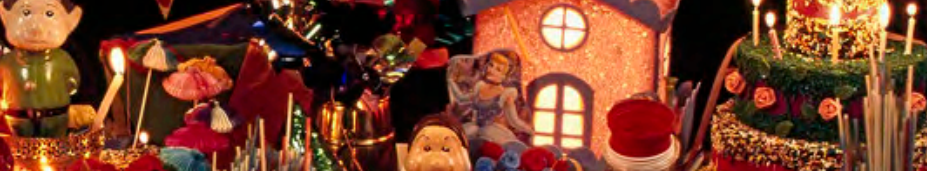

5)

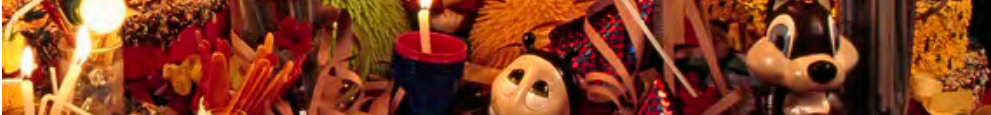

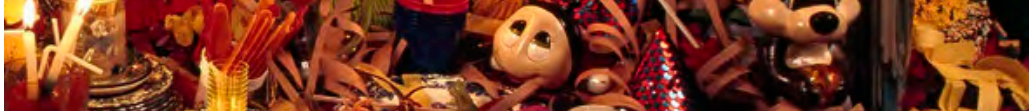

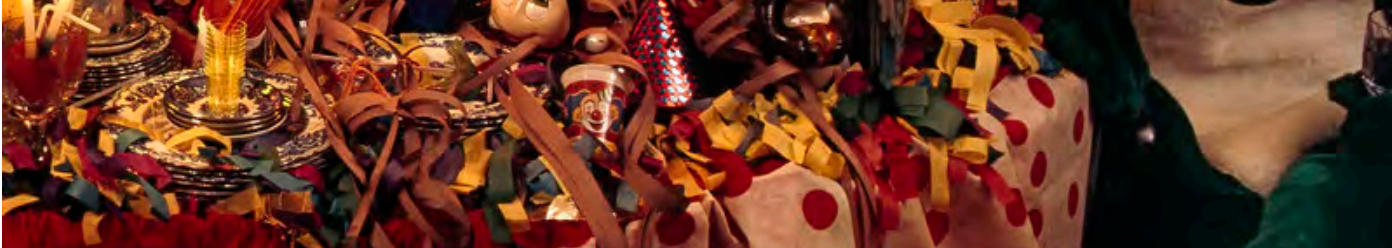

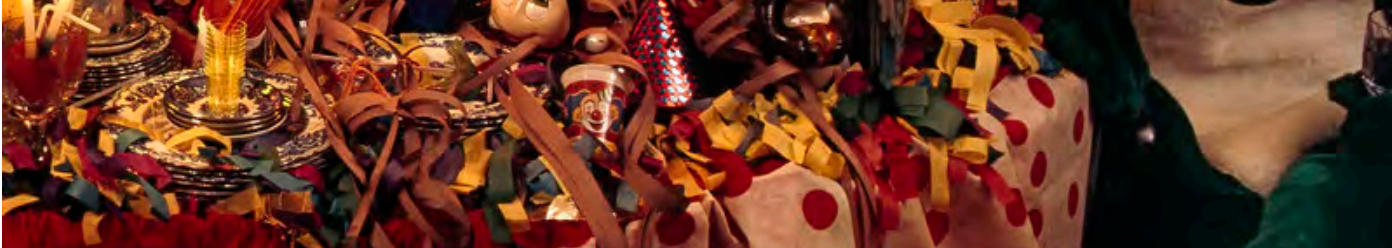

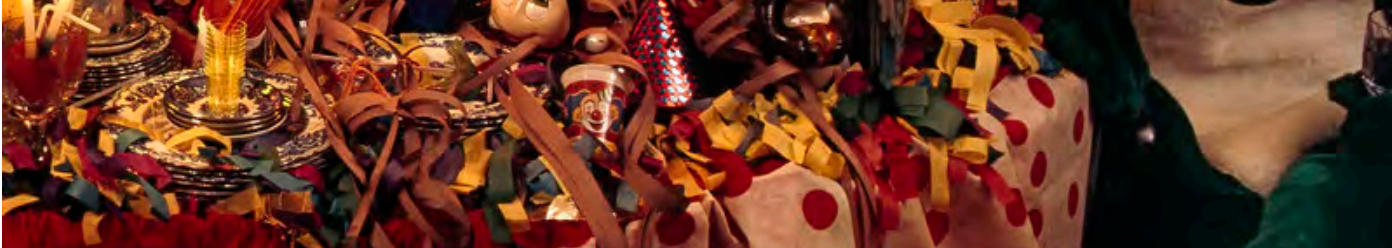




\section{5}

\section{POÉTICA VISUAL DESENVOLVIDA A PARTIR} DO CONCEITO DE TEATRALIDADE 


\subsection{ApresentaÇão da Pó́tica desenvolvida}

\section{$\mathrm{N}$}

este Capítulo irei apresentar os trabalhos plásticos que foram realizados durante o mestrado. Todos os trabalhos que apresento a seguir, tem em comum o período de produção, que se deu com o início do ingresso ao mestrado (Fevereiro de 2012) e se encerraram com a finalização da dissertação (Agosto de 2014). Vale lembrar que alguns destes trabalhos já foram apresentados em exposições ao longo do ano passado e deste ano e outros foram elaborados e registrados especialmente para compor a pesquisa da dissertação.

É importante ressaltar, que neste capítulo, optei por mostrar os trabalhos como se eles fizessem parte de uma espécie de portfólio, acompanhados de imagens e textos bem objetivos (quase técnicos). A idéia de delinear apenas o trabalho plástico é tentar mostrar através de um certo distanciamento, todas as questões que já foram aqui faladas nos capítulos anteriores. Como se sabe, todos estes trabalhos foram realizados sob a luz da idéia principal que guia a pesquisa, que é a tentativa de encontrar a "Teatralidade na vida cotidiana".

Desse modo, seria redundante frisar a cada trabalho quais as necessidades de enxergar as características do tema. 0 pequeno texto que segue anexo a cada série de trabalhos já é suficiente. 


\subsection{Projeto para Finais Felizes}

\section{"O Narrar uma história”}

Quando se fala hoje em dia num final feliz, as pessoas consideram-no uma simples concessão ao público ou uma estraté gia comercial, consideram-na artificial. Mas por séculos os homens puderam acreditar sinceramente na felicidade e na vitória, embora percebessem a dignidade intrínseca da derrota. Por exemplo, quando se escrevia sobre o Velocino de Ouro, uma das velhas histórias da humanidade, leitores e ouvintes sabiam desde o início que o tesouro seria encontrado no final.

Bem, hoje em dia, se alguém empreende uma aventura, sabemos que terminará em fracasso. Quando lemos (...) o Castelo de Kafka, sabemos que o homem jamais ingressará no Castelo. Ou seja, não podemos realmente acreditar em felicidade e sucesso. E isso talvez seja uma das pobrezas de nosso tempo.

Suponho que Kafka tenha sentido algo bem parecido quando quis que seus livros fossem destruídos: Queria na verdade escrever um livro feliz e triunfante, e sentiu que não podia fazêlo. Ele poderia têlo feito, éclaro, mas as pessoas teriam percebido que ele não estava dizendo a verdade. Não a verdade dos fatos, mas a verdade de seus sonhos.

Borges, "Esse ofício do verso" 


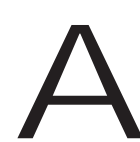

instalação "Projeto para Finais Felizes" parte de um questionamento sobre a produção de arquivos e concentra-se em livros de contos de fadas clássicos. Seleciona e recorta as últimas páginas das histórias que contêm a palavra "felicidade" ou suas derivações. As narrativas e os títulos são subtraídos: restam apenas "finais felizes" e o motivo pelo qual essa "felicidade" foi alcançada.

Esta pesquisa resulta em centenas de parágrafos que, expostos em conjunto, permitem perceber sutilmente que o "fim" acontece por meio de três conquistas: dinheiro/fortuna, casamento/amor, saúde/ cura. Esses mesmos elementos "utópicos", de certa forma, estão presentes nos livros de auto-ajuda. O trabalho objetiva explorar o espelhamento do imaginário na vida cotidiana, ou a busca incessante de realizações na vida contemporânea.

Como recados de um mural, cada final repete a demanda constante do que se entende por plenitude. Essa demanda é ressaltada pela grande quantidade de quadros expostos. A aparente esperança presente na narrativa dos contos de fadas está ali para ser confrontada. $\mathrm{O}$ excesso evidencia uma anulação das possibilidades, mas, em contrapartida, clama por uma vivência. Pode o imaginário encontrar-se com a realidade?

A instalação é composta por páginas de finais felizes de diferentes livros infantis (contos dos irmãos Grimm, de Hans Christian Andersen e da Coleção Reino Infantil) emolduradas com madeira e vidro. Os quadros em pequenos formatos preservam 0 tamanho original de cada livro e ocupam o espaço de uma única parede de $9 \mathrm{~m}$ de comprimento por 2,20m de altura, aproximadamente. Os quadros são ordenados pelos respectivos conjuntos de coleções e seguem a ordem crescente do número das páginas de cada história. 

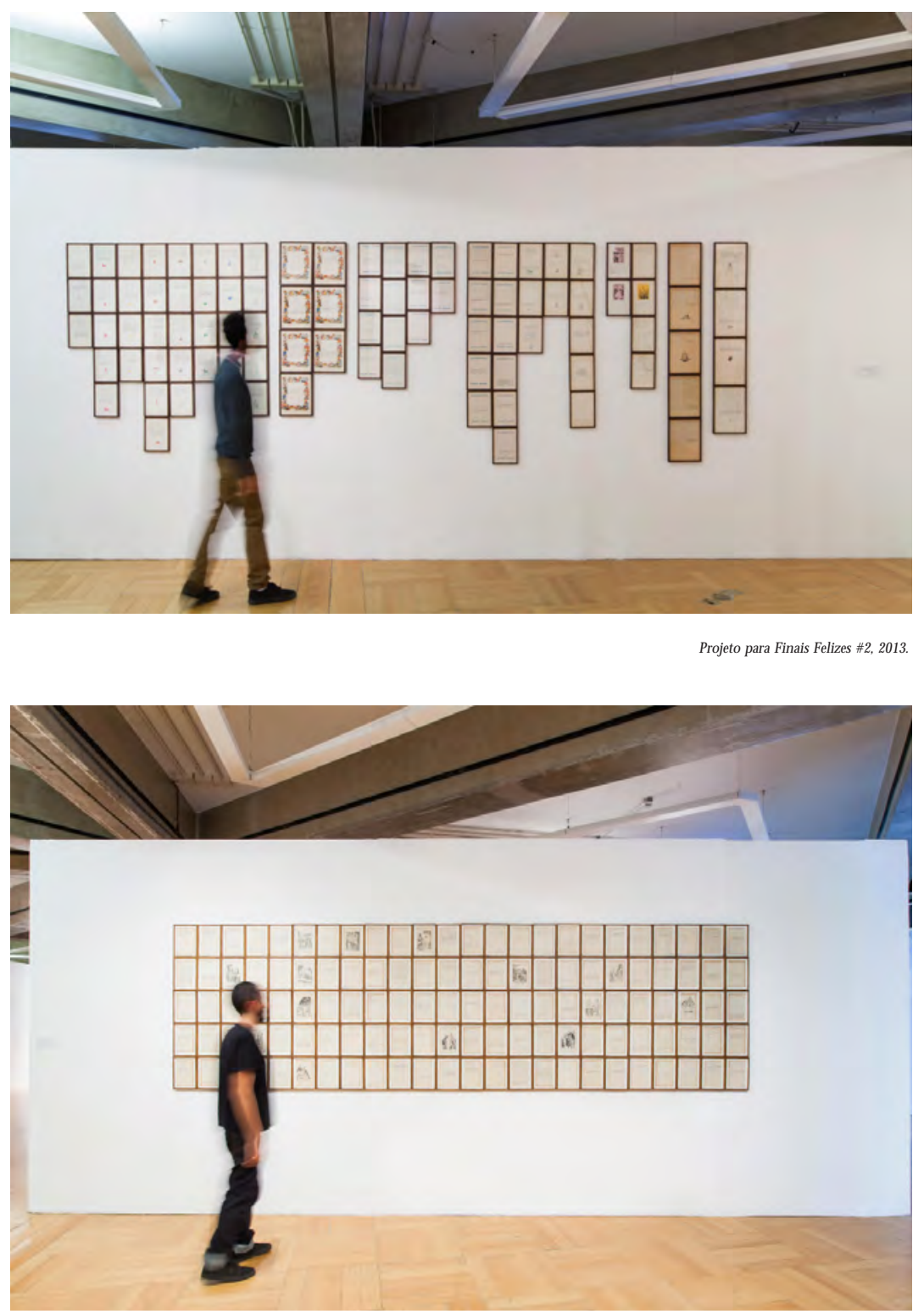

Projeto para Finais Felizes \#3, 2013 Instalação apresentada no Programa de Exposicoes do Paco das Artes em São Paulo-SP. Vista geral da exposição 


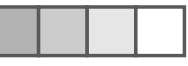

$\oplus$

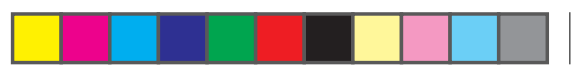

POÉTICA VISUAL DESENVOLVIDA A PARTIR DO CONCEITO DE TEATRALIDADE

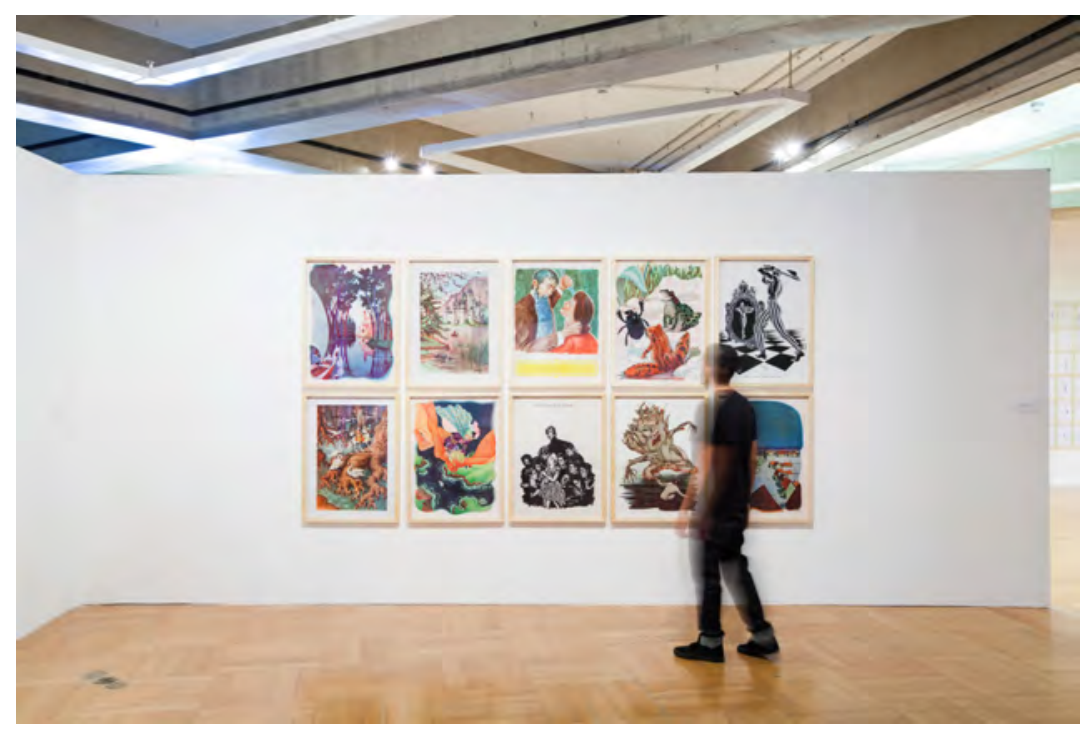

( $)$

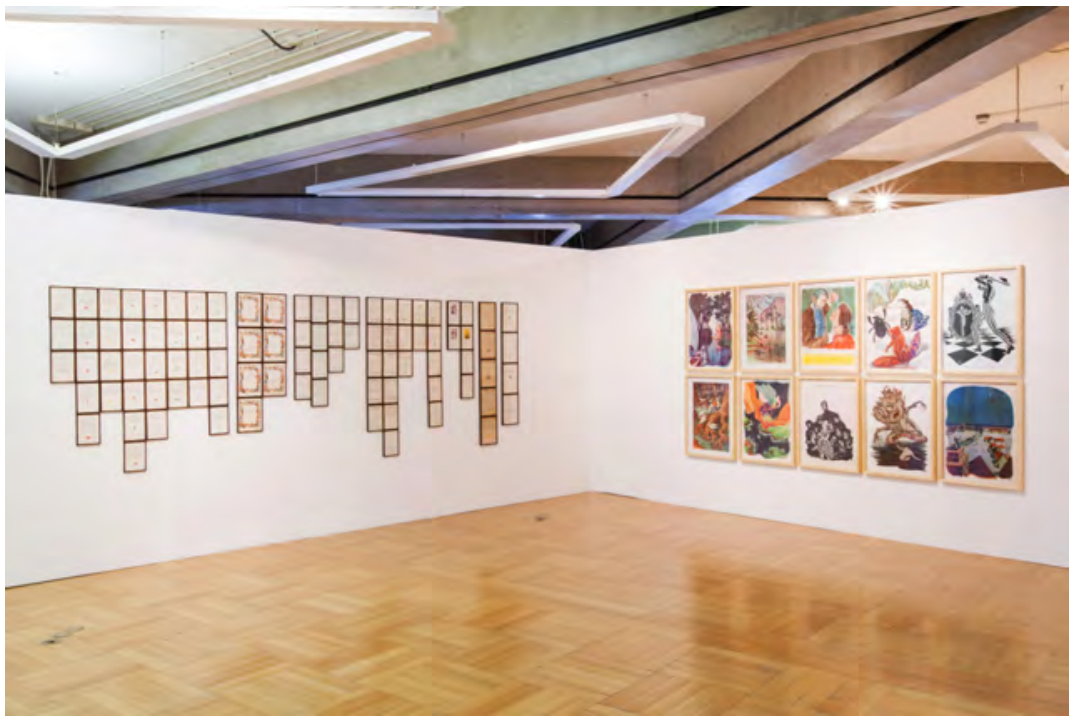



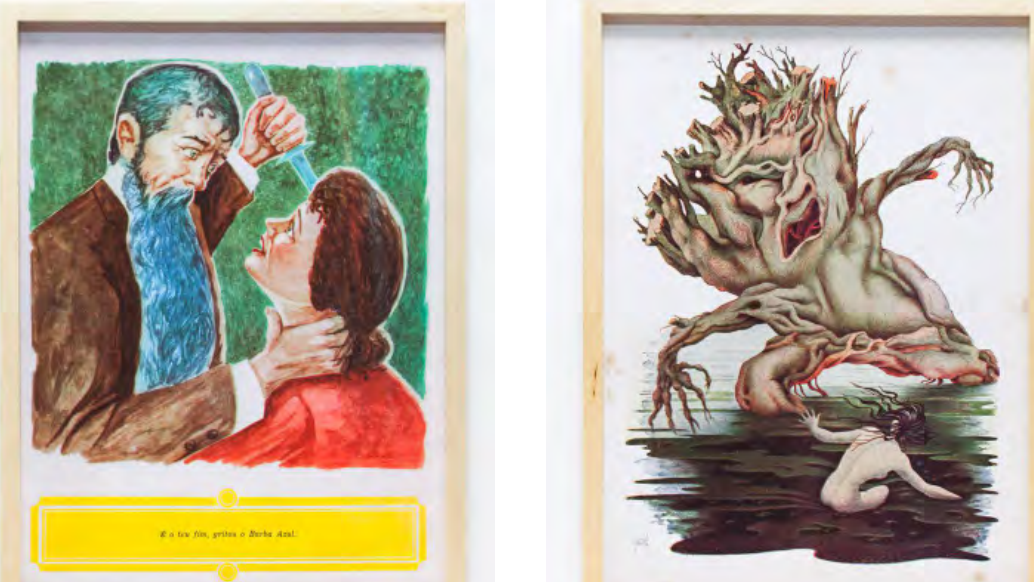

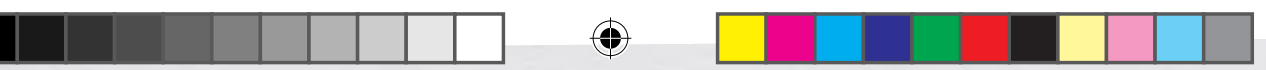

O casamento foi celebrado nesse mesmo dia, à tarde, com a assistência da fada Misteriosa, que deu a Mirmila a felicidade em troca da sua boa ação.

O príncipe foi, durante o resto de sua vida, o mais feliz dos mortais e a rainha nunca teve motivo para se arrepender de ter consentido em tal casamento. 


\subsection{MiCKEY's DAILY WORK 210MIM/400PIX}

\section{A instalação fotográfica "Mickeys's Daily Work: 210mim/400pix" apresenta 400 fotografias que, em um período de 210 minutos, imortalizam o contato entre fa-} mílias de férias e o personagem Mickey na Disney.

As imagens, expostas cronologicamente com a informação do horário em que foram captadas, exibem uma somatória de eventos que representam a duração de um dia de trabalho do Mickey. Impressas no formato tradicional dos antigos álbuns, também buscam ressaltar um instante em que a dicotomia entre realidade e ficção se dilui.

Nesse momento do encontro, percebo que, ao mesmo tempo em que os visitantes se aproximam da fantasia, o personagem encantado também é transportado para a realidade de uma rotina de trabalho. Há portanto uma intersecção entre esses dois universos distintos, e a repetição da ação anula tanto o sentido do personagem fictício quanto a singularidade de cada família.

Como artista, eu observo, mas também participo da vivência. Ao exibir minha própria imagem misturada com a de outros 400 turistas anônimos, tento demonstrar para além de um olhar crítico, uma postura convencional de aceitação. Eu também me relaciono e sou inserida nessa busca da realização dos sonhos, procurando documentá-los de forma poética.

A instalação Fotográfica "Mickey's Daily work: 210mim/400pix" é construída em 2 paredes em "L" que apresentam no total 400 fotos impressas em tamanho álbum $(12,2 \mathrm{x} 19 \mathrm{~cm})$ em papel brilhante com margem, fixadas lado a lado cronologicamente.

A primeira parede (5,30m de comprimento e 2,20 de altura) 
exibe as fotografias que foram tiradas durante o período matutino do evento na Disney e a segunda parede $(5,0 \mathrm{~m}$ de comprimeto e 2,20 de altura) mostra as imagens captadas no período vespertino. Ambas as paredes apresentam, a baixo do conjunto de imagens, um adesivo escrito em cor preta com os horários referentes ao período em que as fotografias foram captadas. Cada fotografia também exibe a data e o horário exato do clique.

Em uma das paredes externas da instalação, há dois pe quenos quadros próximos ao título da obra. Um quadro contém 0 livro de autógrafos com a assinatura do Mickey e o outro apresenta o folder da programação do evento documentado. Sugiro também um adesivo de parede em cor preta com o título do projeto.

As fotos anexas abaixo, apresentam uma montagem teste que fiz para exemplificar o projeto, este trabalho não foi exposto em nenhum local e somente o montei para apresentar nesta dissertação.

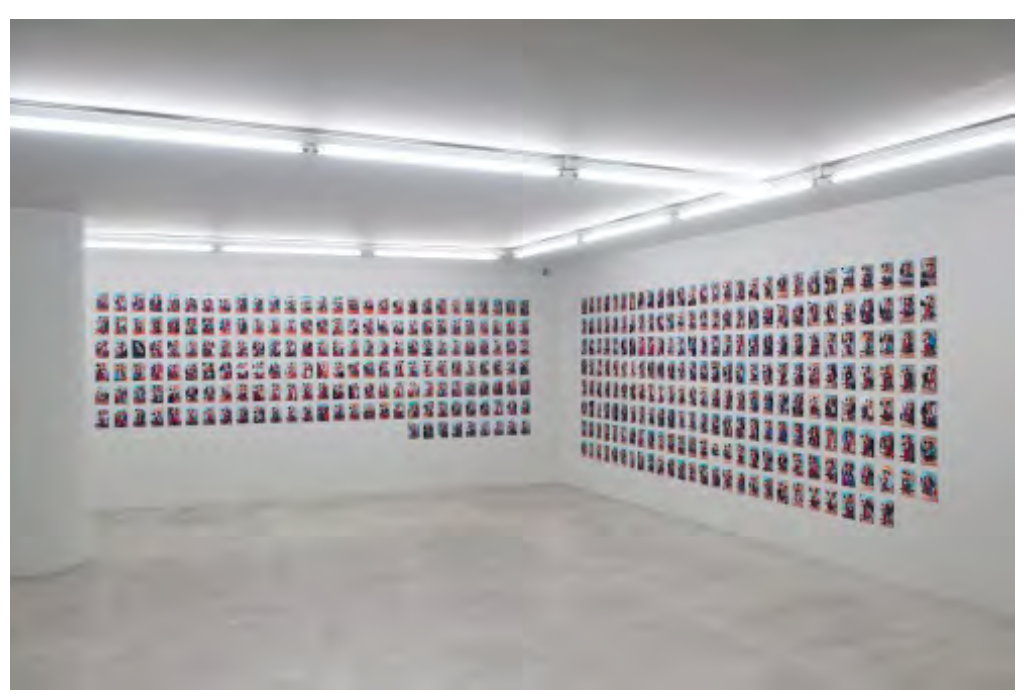

Vista da Instalação. 

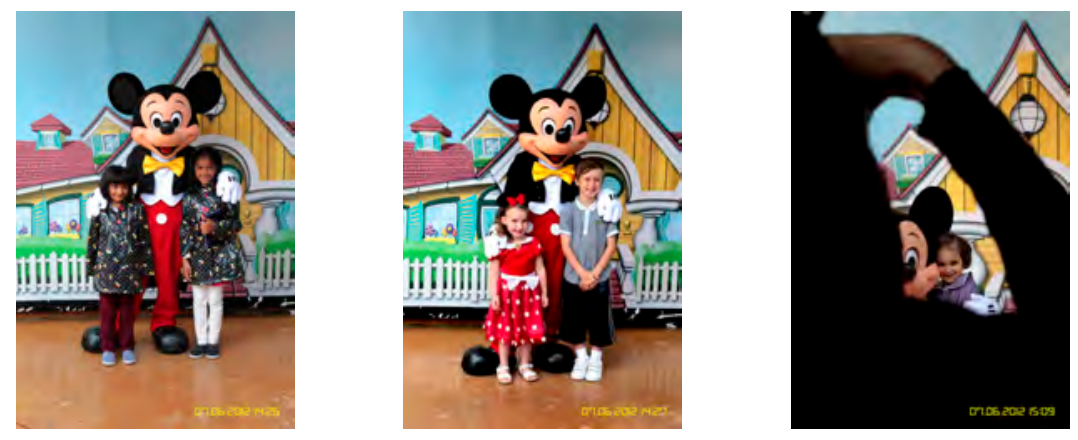

$\oplus$
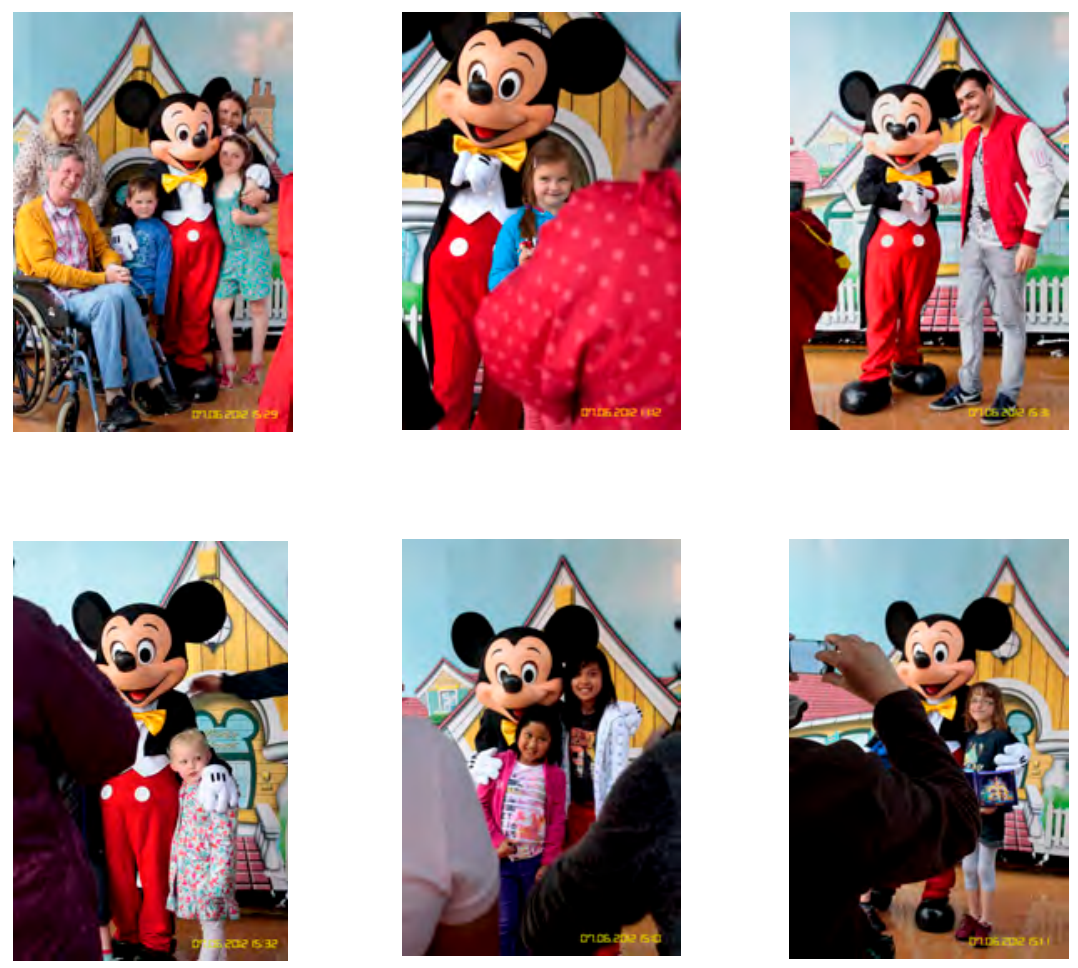

Detalhe das fotografias que compõe a instalação 


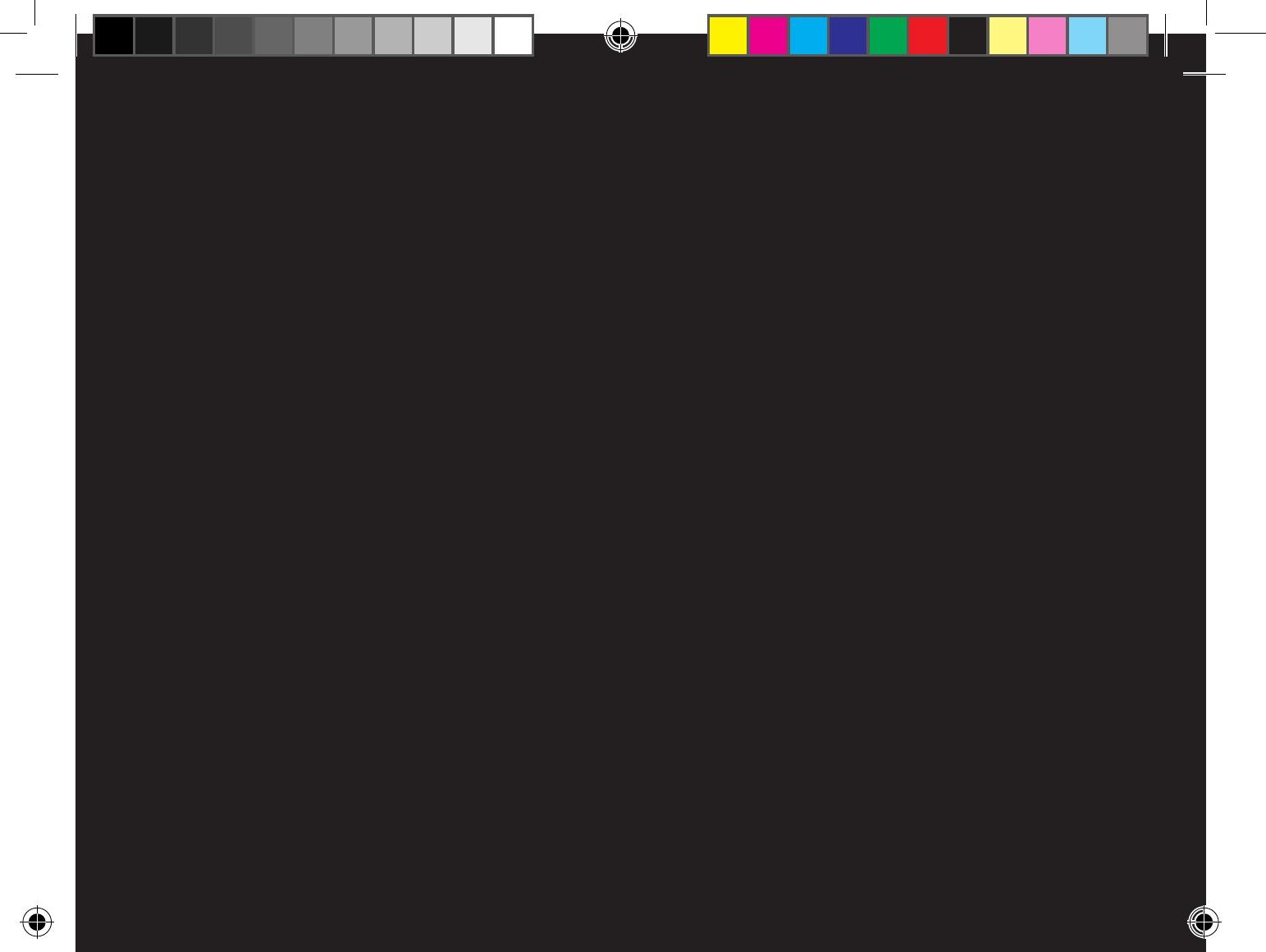




\subsection{NÍVEIS}

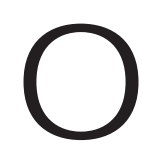

ensaio fotográfico Níveis busca discutir a questão do auto-retrato através da idealização em contraposição a realidade da percepção do corpo. É composto por 18 dípticos em que eu me fotografo ao lado de banhistas de três diferentes gerações - crianças, adultos e idosos - caracterizados por três "tipos" físicos distintos - magra (0), "médio/ideal", gorda (0). Em cada uma das imagens, os indivíduos são registrados de frente e de costas com o objetivo de evidenciar a totalidade do corpo quase por completo.

Nesta série, eu me coloco na imagem como uma unidade de medida, que além de subjetiva como modelo, é ao mesmo tempo variável. Em cada comparação, meu corpo se transforma e pode ser visto de diferente maneiras de acordo com quem estiver ao meu lado. Cada um influencia na percepção do outro. Ou seja, me torno um padrão de repetição fictício. E o corpo ideal depende da observação subjetiva de cada um. Também existe uma demanda da presença do outro para que eu me observe e construa a imagem de mim mesma. $\mathrm{O}$ auto-retrato só acontece através dessa possibilidade dupla de se relacionar.

Com o objetivo de evidenciar a temática da classificação e organização de arquivos, sugiro uma montagem aleatória das fotografias do presente ensaio. Essa opção evita a classificação e a comparação previsível entre os "tipos" apresentados e auxilia na construção do auto-retrato. 


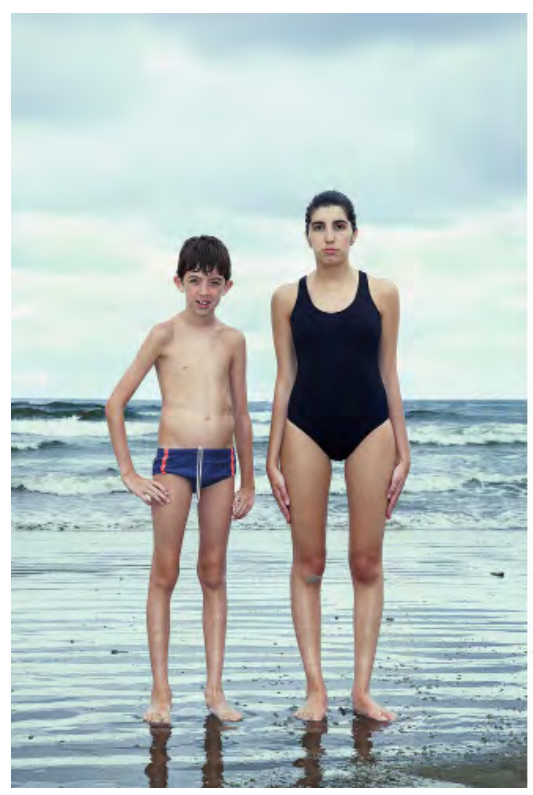

(1)

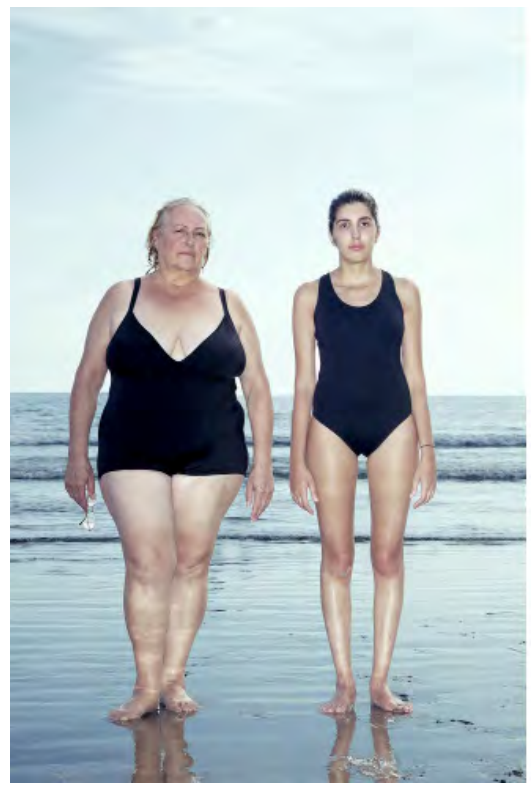

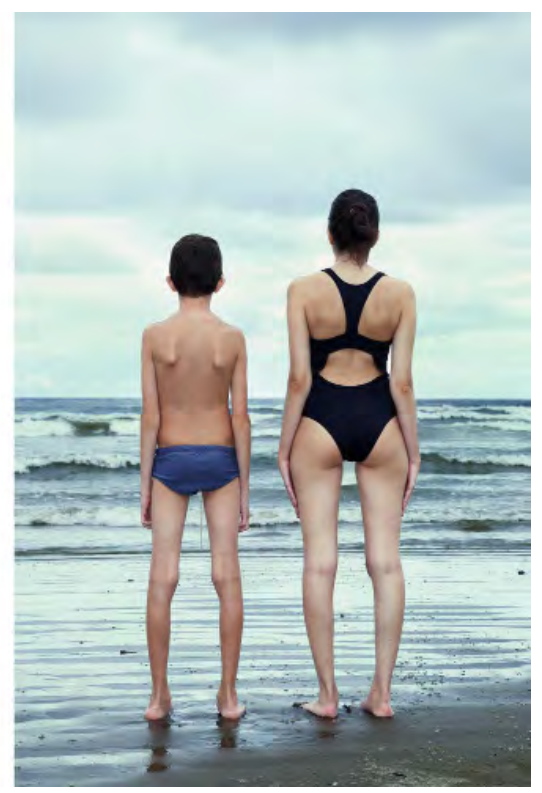

Detalhe: Níveis \#1, 2013.

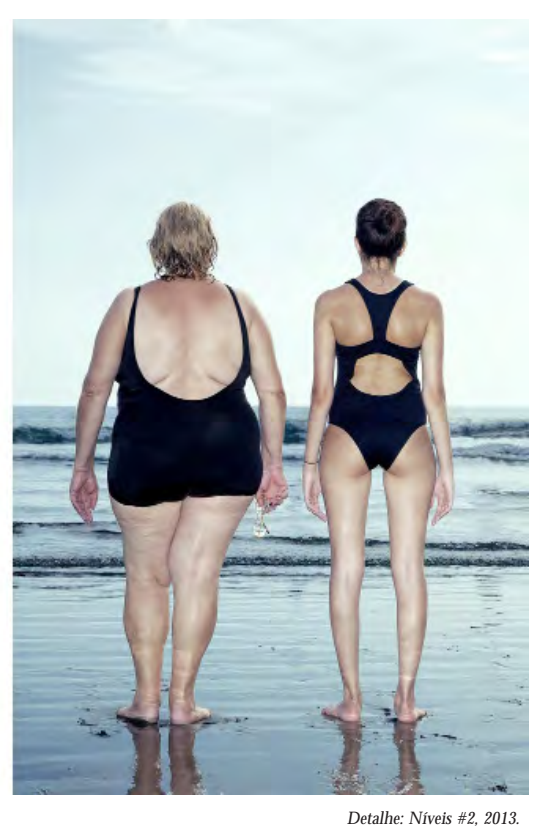




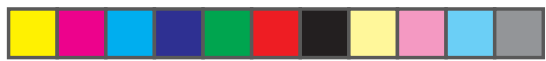

POÉTICA VISUAL DESENVOLVIDA A PARTIR DO CONCEITO DE TEATRALIDADE
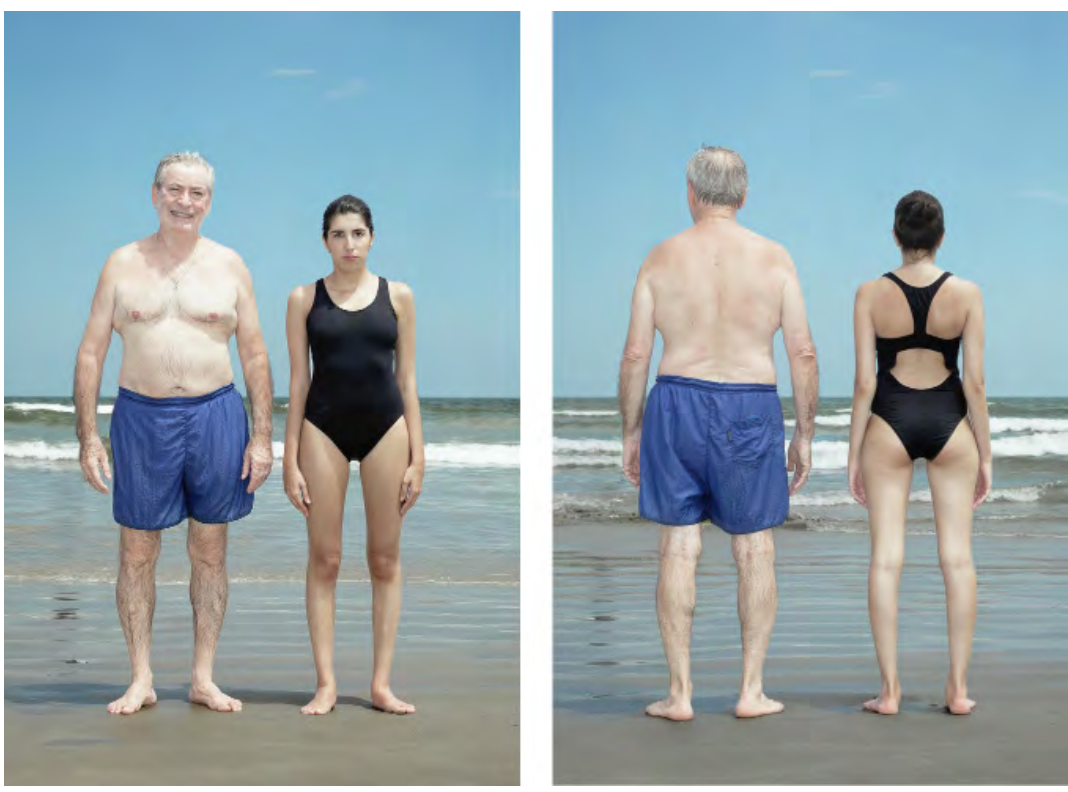

$\varphi$
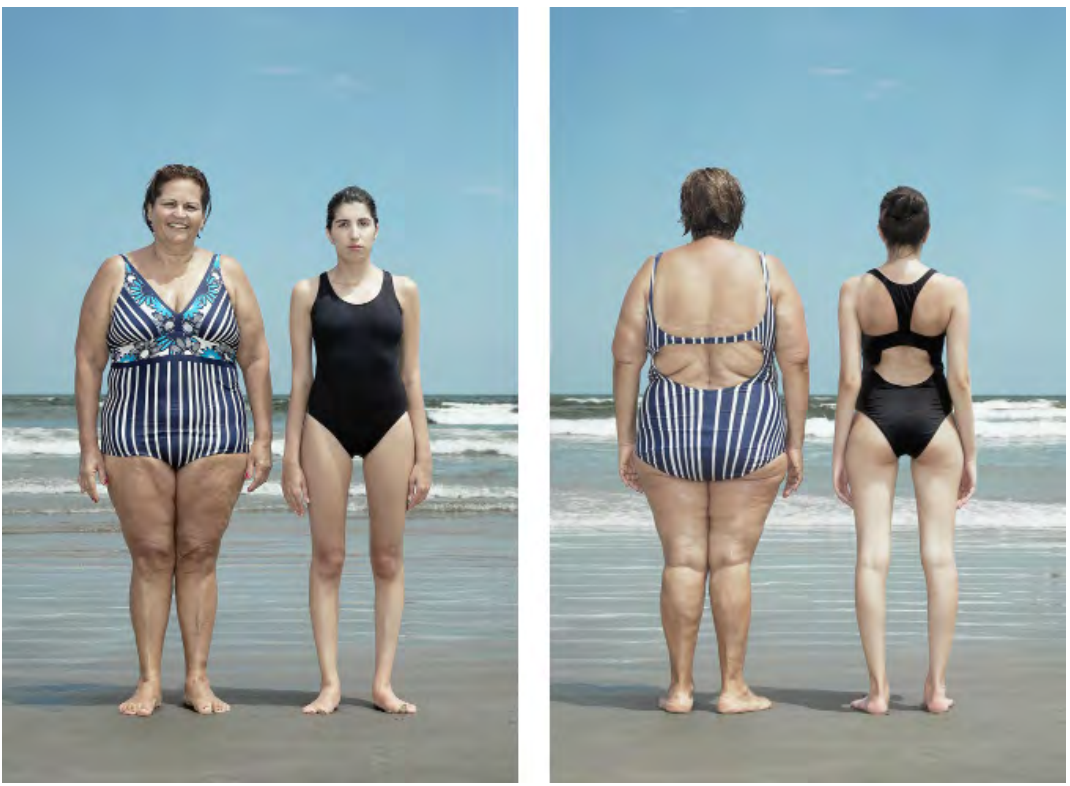

Detalhe: Níveis \#8, 2013 


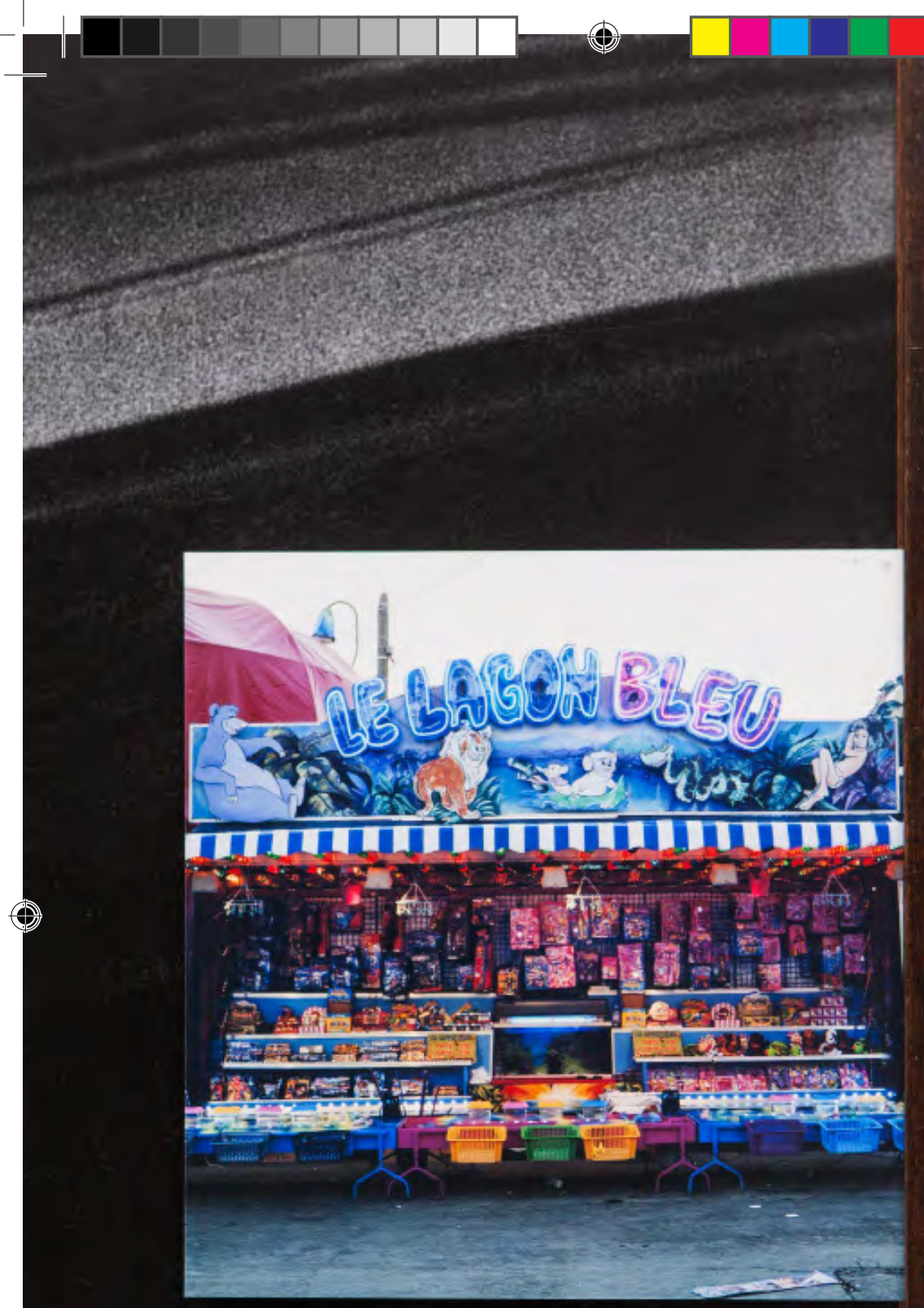


A série de fotografias "A Criança e sua Família" exibe retratos em preto e branco de famílias em seus trajes de passeio, crianças na praia e uma criança na sala de estar de sua casa. Estas imagens foram encontradas em sebos de Paris e ampliadas em grande formato. Dentro de cada moldura é anexada outra pequena fotografia colorida que apresenta imagens de parques de diversões.

O ensaio brinca com as inversões. Os retratos de família, que a princípio estavam guardados em um álbum, são redimensionados para uma grande escala. Já as fotografias das paisagens de um parque de diversão repleto de detalhes são apresentadas em tamanho pequeno como as fotos de um álbum.

Ao instalar os dois pontos de vista numa mesma moldura, proponho discutir as possibilidades de registrar e guardar as memórias: imagens apropriadas são somadas a imagens captadas por minha câmera fotográfica. Por um lado, constata-se a idealização da espera por um momento de lazer: são retratos aparentemente posados em que houve alguma direção. Por outro, observa-se com dificuldade a real vivência de um parque de diversão: são fotografias em que não aparecem pessoas ou em que elas estão desfocadas.

A família apresenta-se aqui como uma primeira estrutura a oferecer para as crianças os elementos ficcionais para tratar de uma felicidade idealizada tanto no espaço da casa como nos locais de lazer. Configura-se assim, como uma ação de reflexão dentro de uma pesquisa mais ampla sobre a criação de cenografias da vida real e a teatralidade da vida cotidiana. 


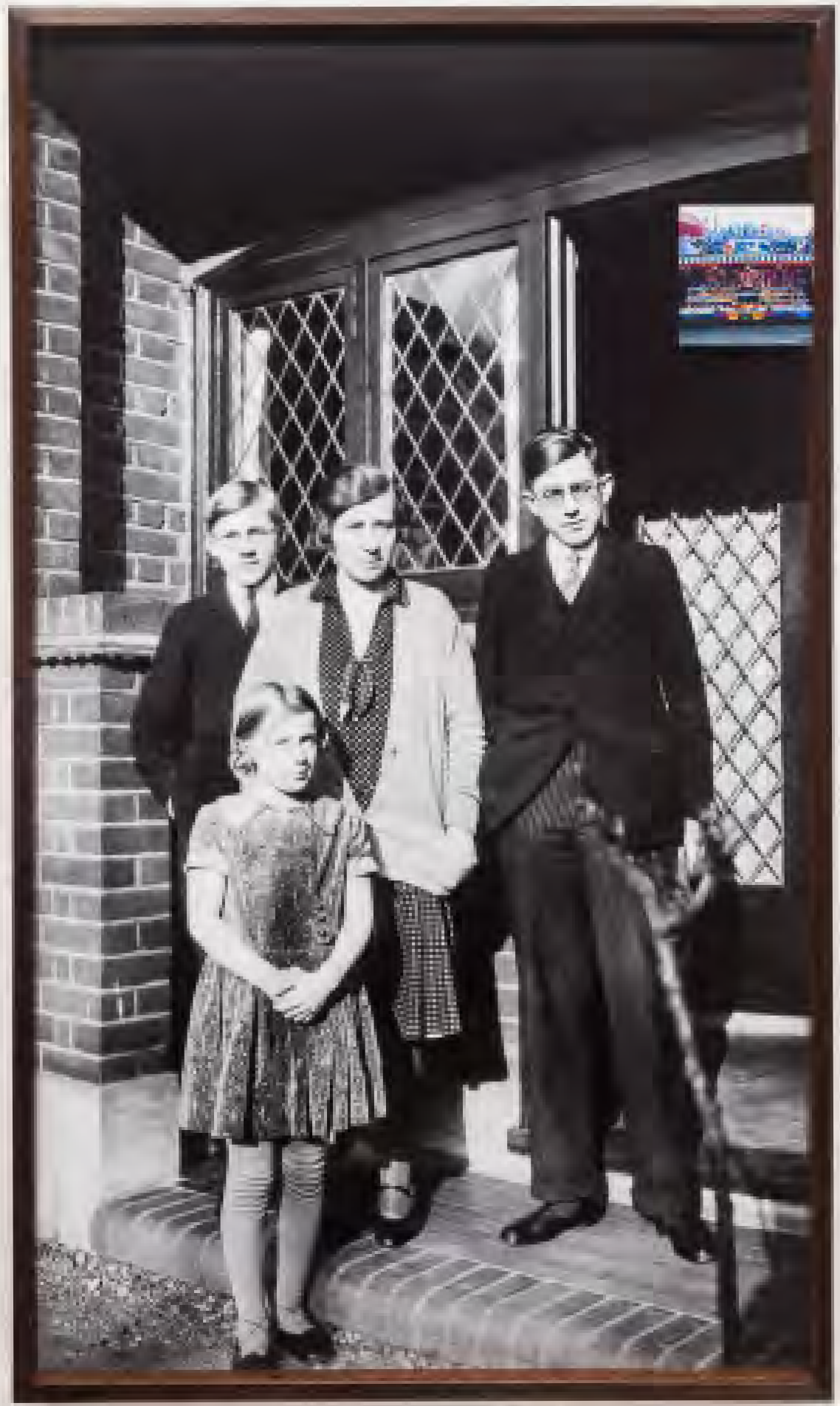

“A Criança e sua Família \#1", 2013. 


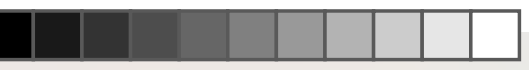

(4)
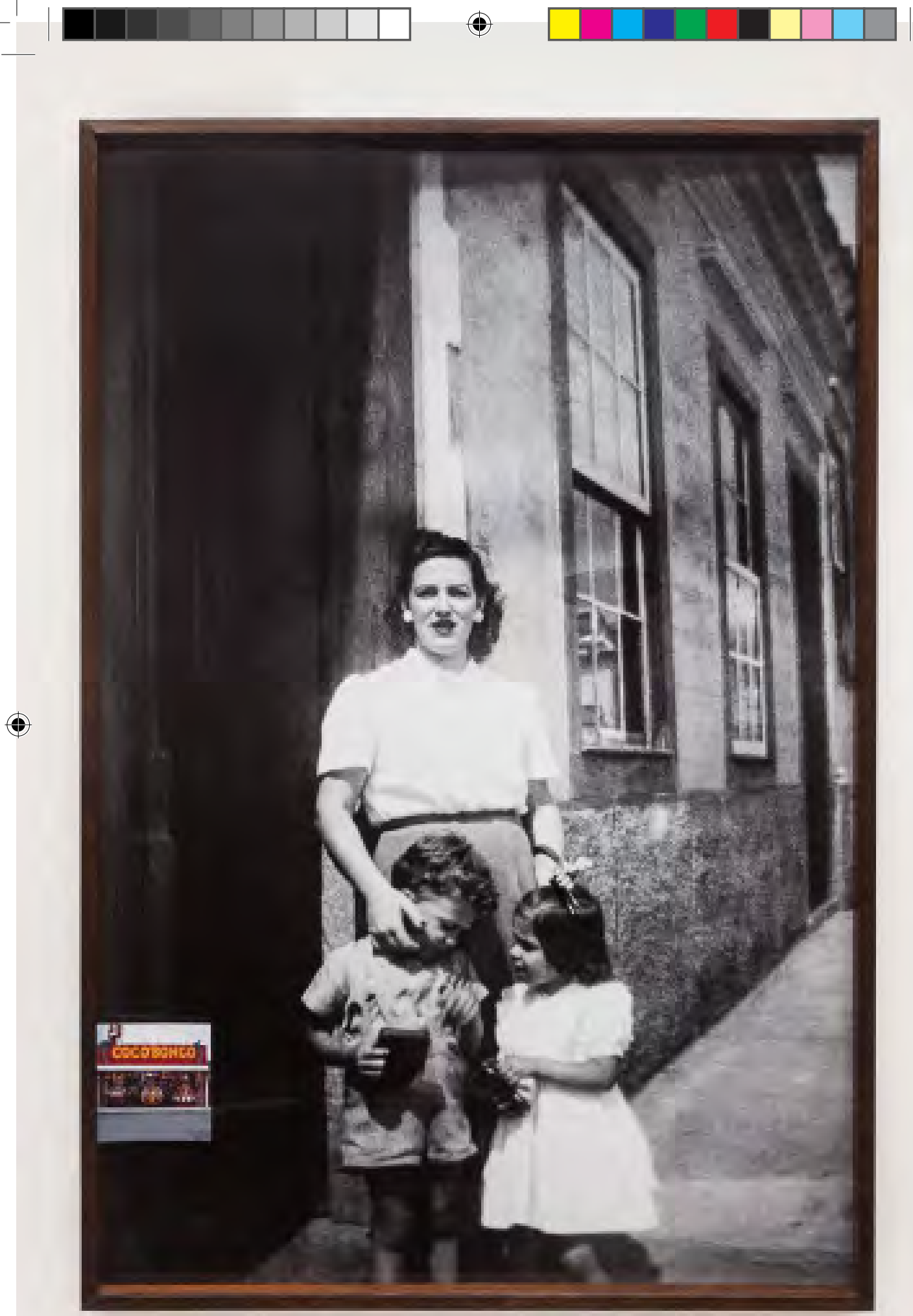

$\oplus$ 


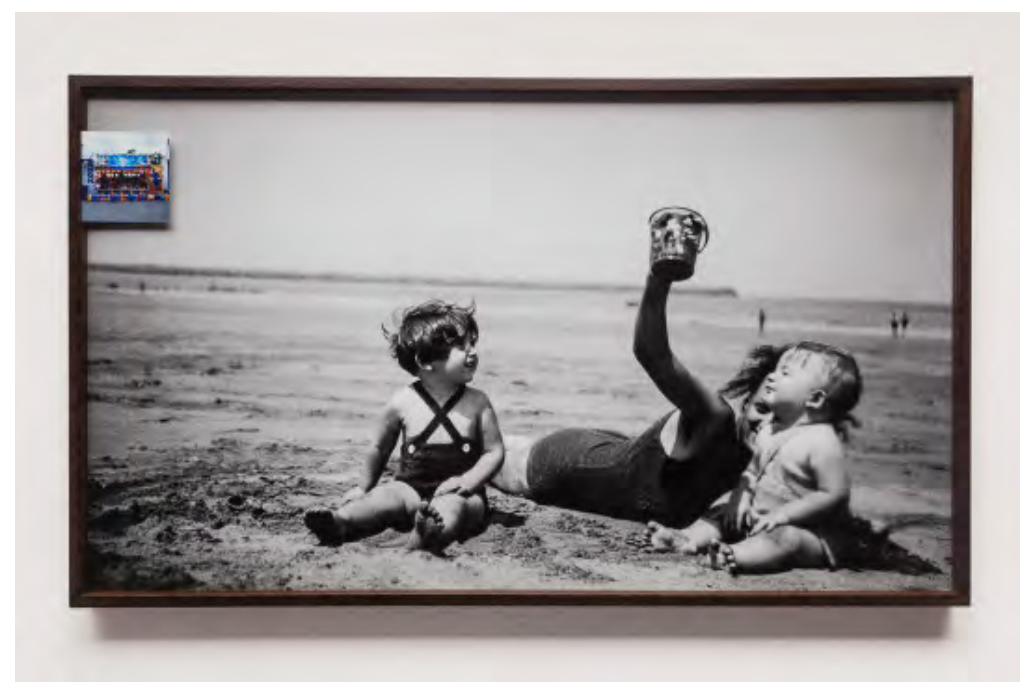

“A Criança e sua Família \#3”, 2013.

$\oplus$

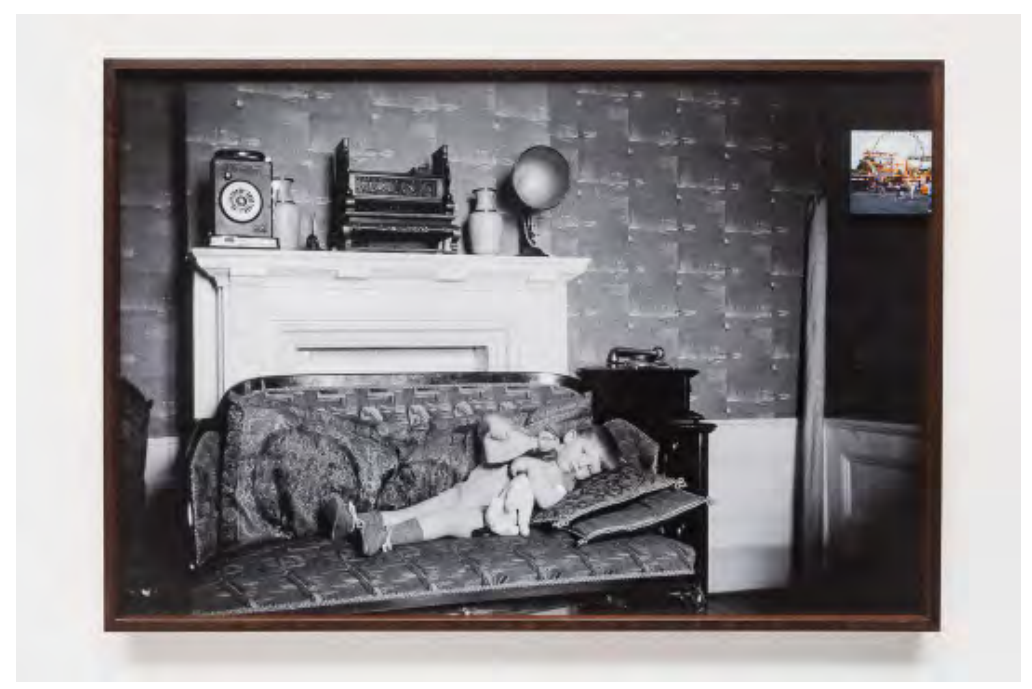

“A Criança e sua Família \#1", 2013. 


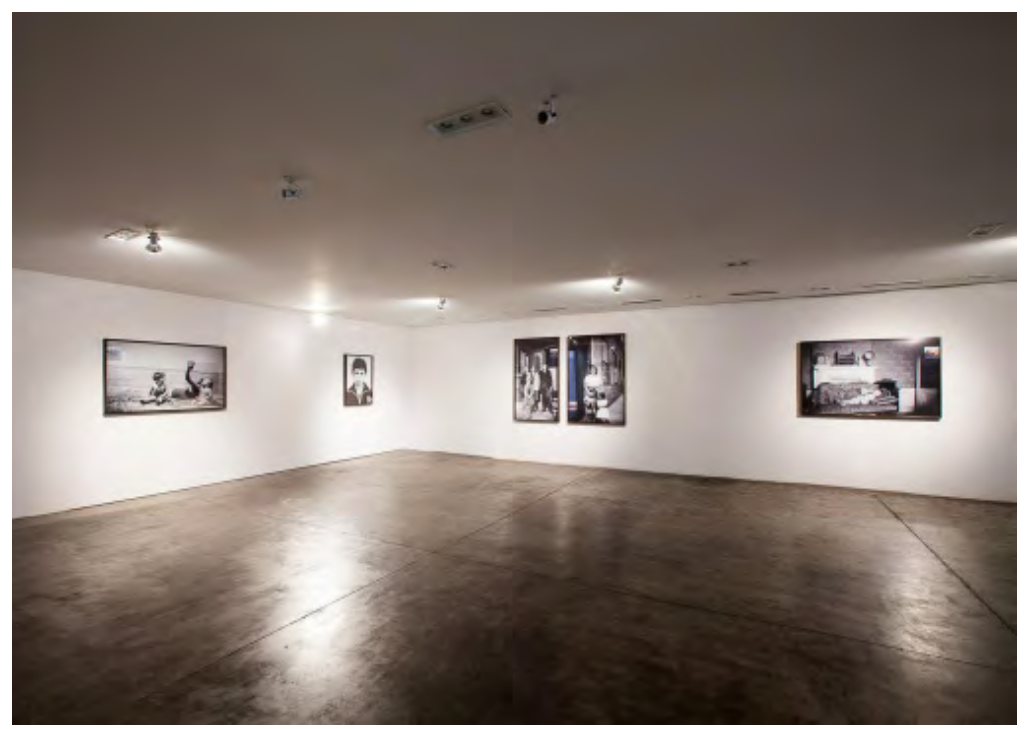

Vista geral do espaço, 2013. Fotografias apresentadas na Galeria Baró.

$\oplus$ 


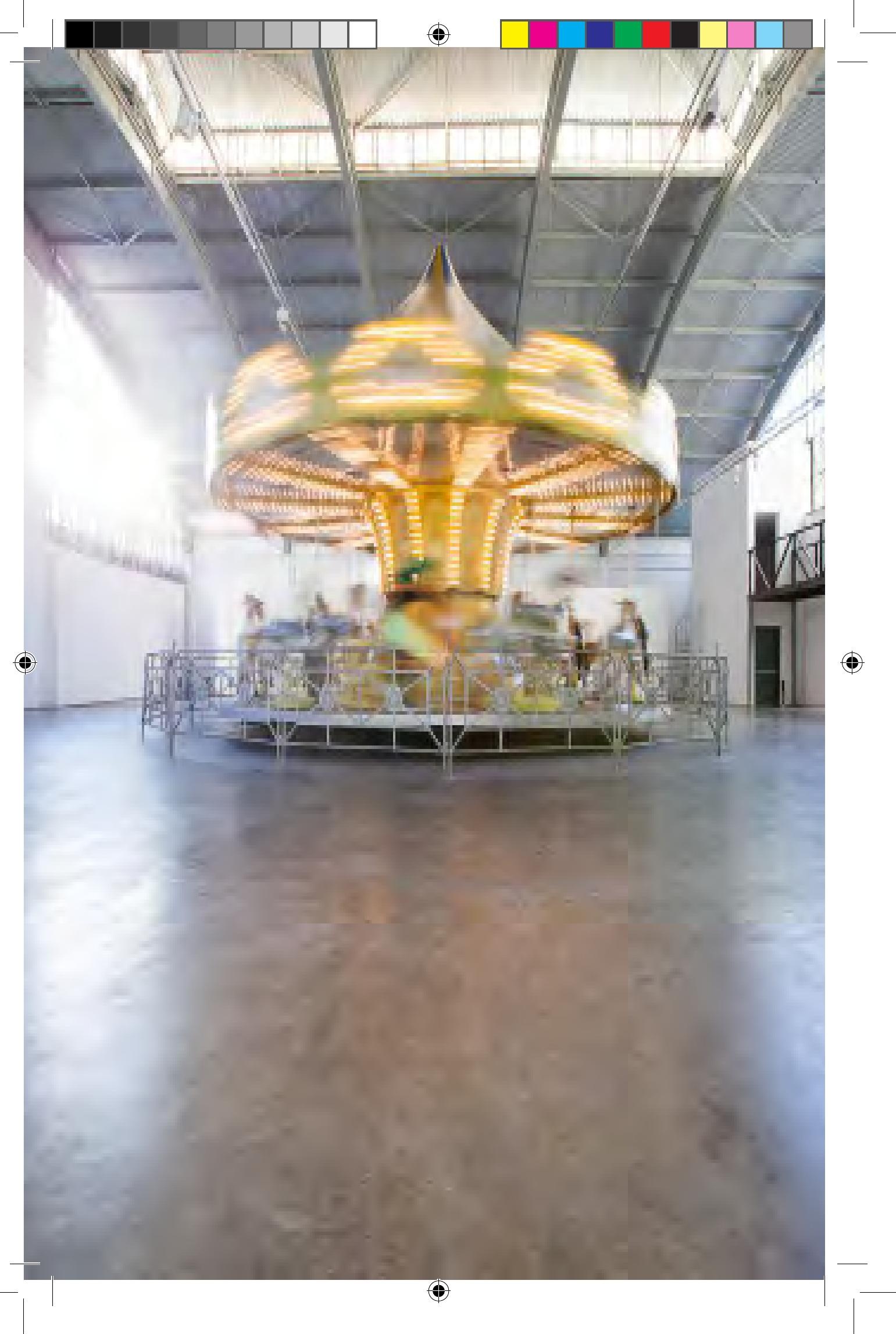




\subsection{Cartografia Afetiva}

série de trabalho chama "Cartografia Afetiva" é composta
por 22 fotografias. Esse trabalho consiste em uma catalo-
gação de todos os carrosséis que encontrei na cidade de Paris durante um período de Fevereiro a Agosto (período no qual realizei uma Bolsa de residência Artística cedida pela FAAP).

No final do ano passado fiz uma montagem para este trabalho, utilizando fotografias polaróides e outros objetos para caracterizar cada carrossel encontrado. Desta vez, busco uma nova formalização que modifica a idéia: procuro nesta instalação evidenciar a imagem de cada carrossel em separado. Assim, scaneio apenas a fotografia das polaróides e as amplio em tamanho $57 x 77 \mathrm{~cm}$, a baixo de cada imagem estará caligrafado com tinta preta o endereço de cada carrossel encontrado.

A instalação "Mapeamento/ Carrosséis" é composta por 22 fotografias de $57 x 77 \mathrm{~cm}$ de diferentes carrosséis encontrados espalhados pela cidade de Paris no ano de 2011/2012. As fotografias são dispostas lado a lado de cima abaixo em uma ou duas paredes ocupando um espaço total de $9 \mathrm{~m}$ de comprimento por 2,20m de altura, aproximadamente. 


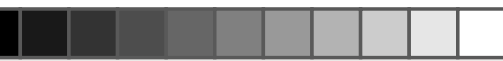

(†)
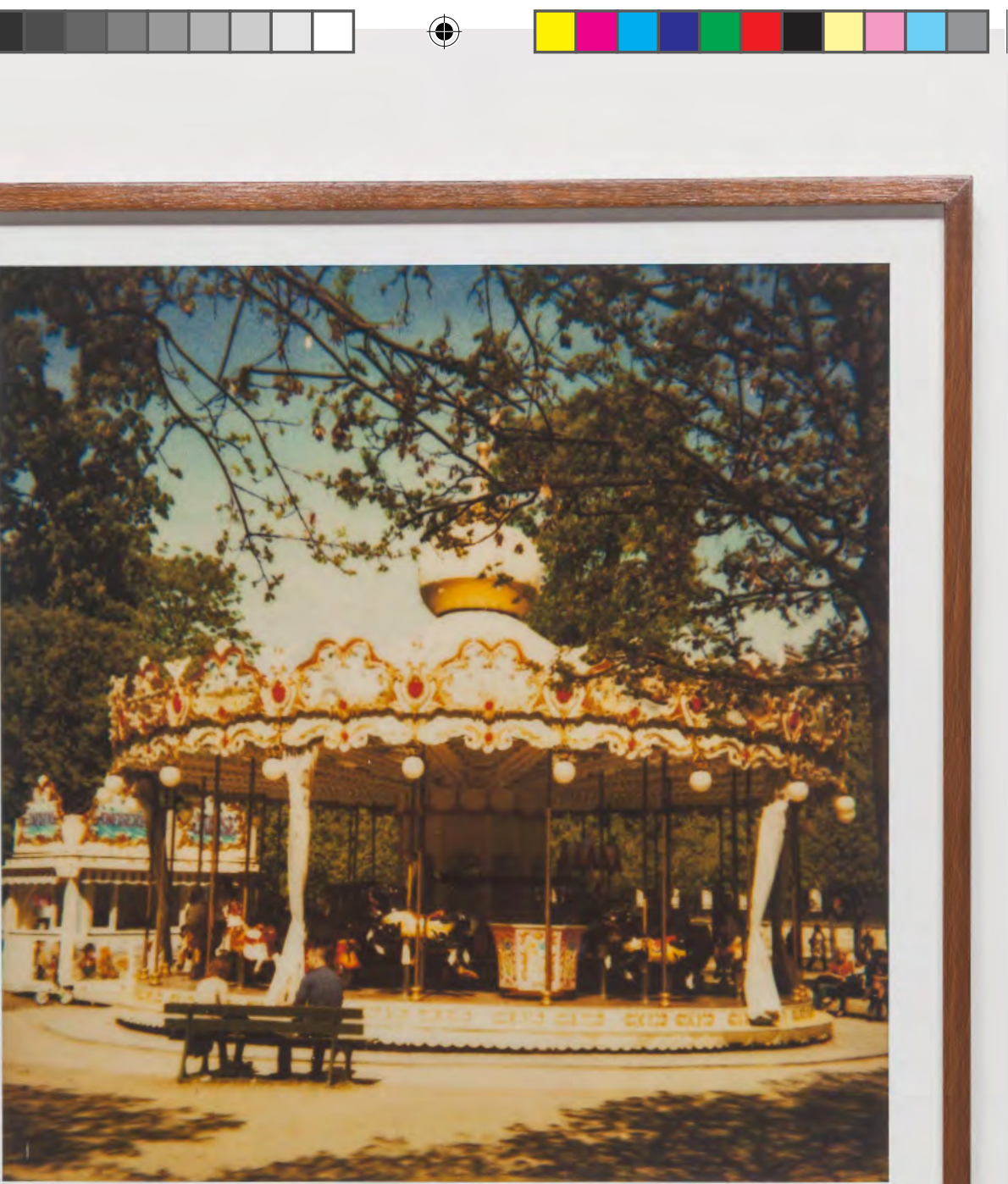

Manège Le Carroussel sibué au coeur du Jardin des Tulleries vo PARIS

Cartografia Afetiva \#1, 2013. 


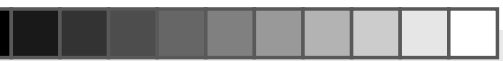

$\oplus$
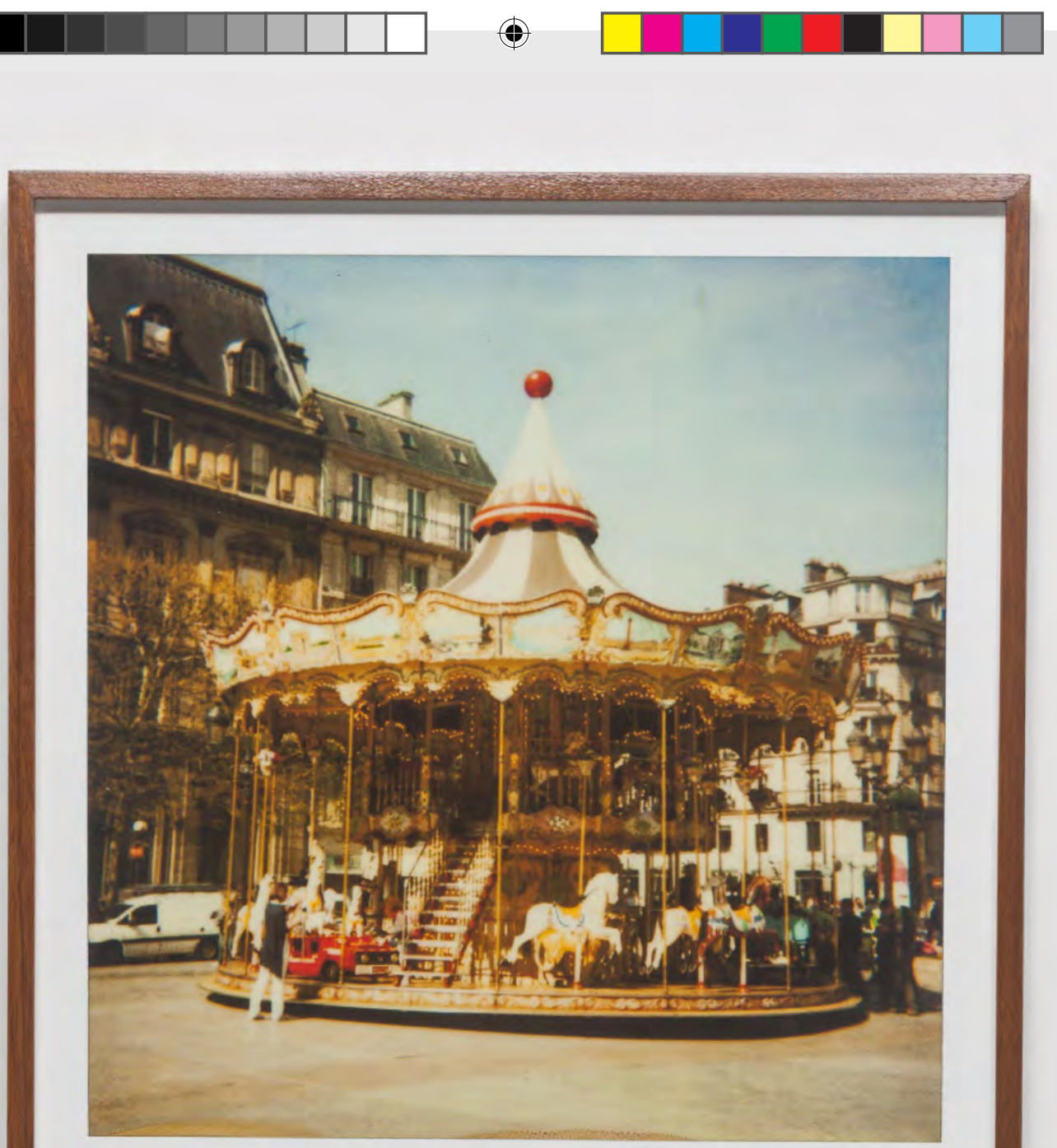

Menège Le Carroussel Mátro situé a la Place De L' Hôtel de Vile La Belle Epogyà 4e PARIS

Cartografia Afetiva \#2, 2013. 


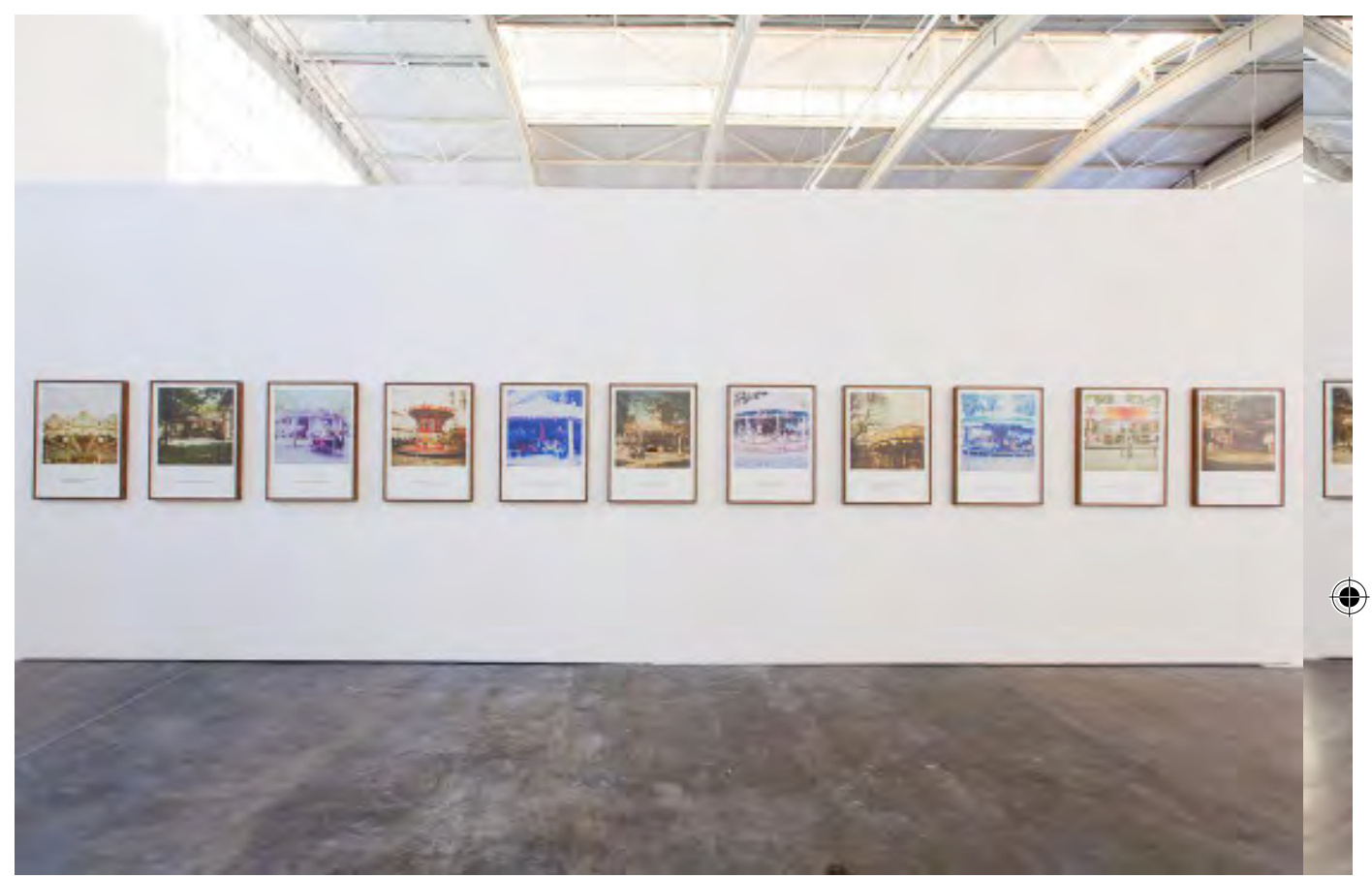



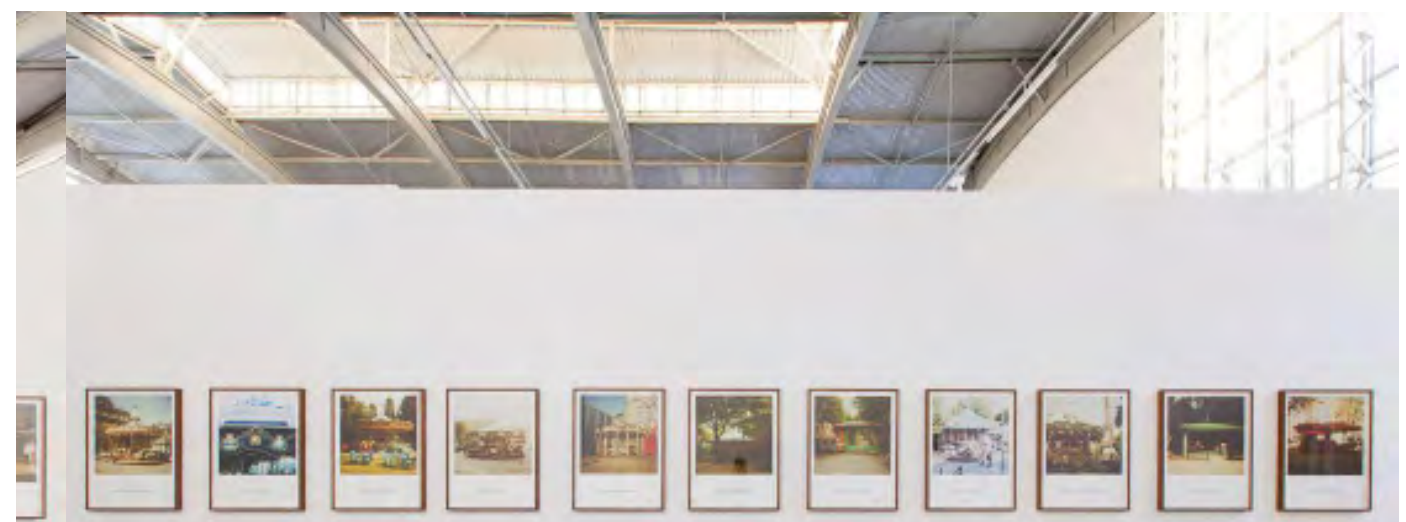

(†) 


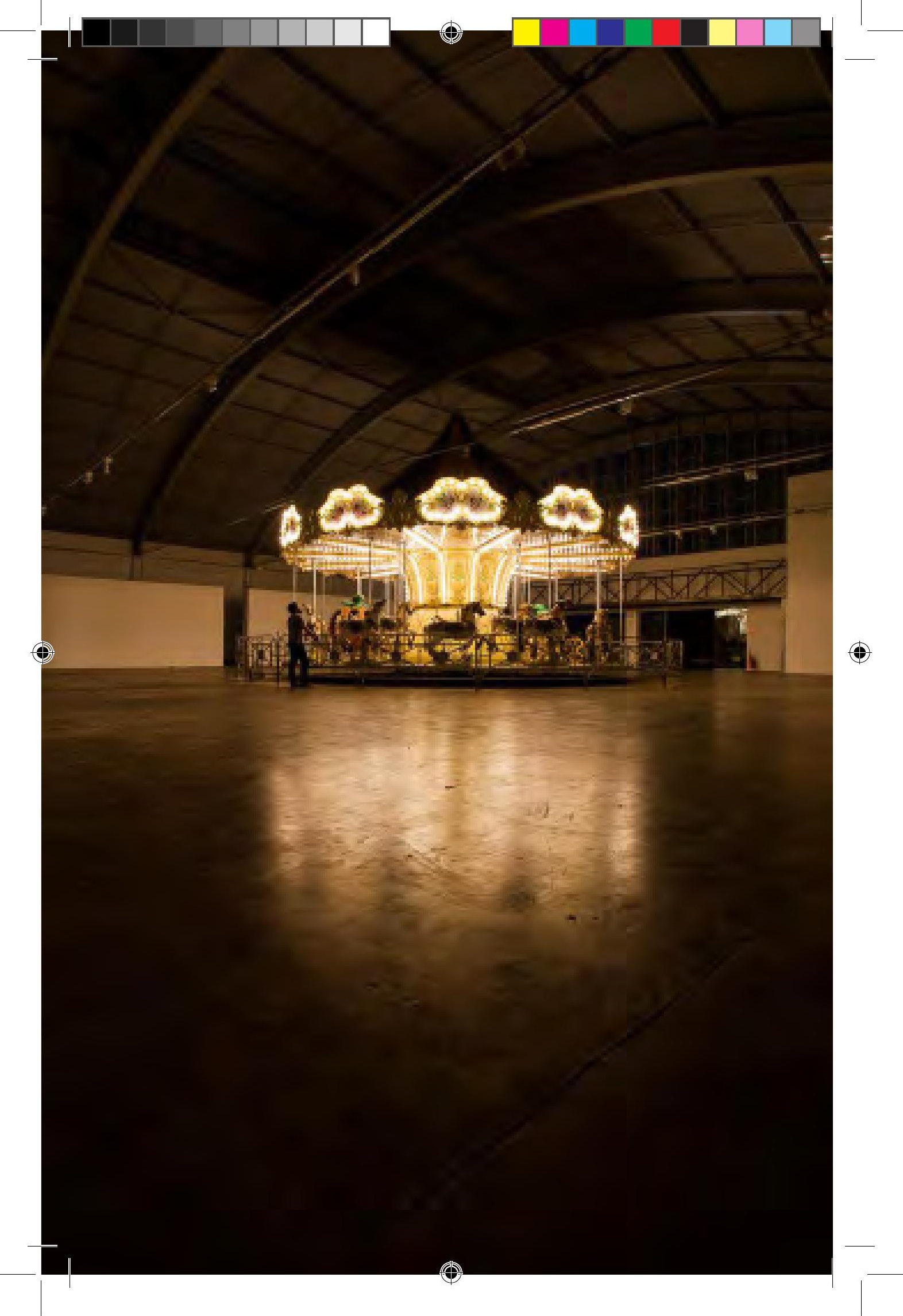




\subsection{CONCLUSÃO DESTE PROCESSO VISUAL: ESTUDO PARA INVERSÃO}

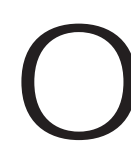

trabalho "Estudo para Inversão" engloba a instalação de um carrossel em tamanho real (com diâmetro de 12 metros) dentro de um amplo galpão. Nesta instalação eu faço uma intervenção no motor e altero o movimento de forma que os 24 cavalos que compõe a totalidade do brinquedo passam a andar para trás. A amplitude do carrossel dentro do espaço interno do cubo branco, o alto ruído de seu motor e seu movimento modificado provocam a inversão da diversão.

O carrossel trás um desejo de reativar memórias da infância. Entretanto, girado ao contrário desperta a memória de uma representação ou, ainda, recorda-nos de vivências que nunca existiram. Com esta ação tento materializar no espaço questões sobre a ficcionalização do imaginário infantil e sobre os rituais do lazer.

A utopia da construção de cenários para garantir a demanda da felicidade instaura sua fisicalidade em grande formato. Há uma melancolia no objeto que sempre teve a importância de idealizar a realidade e nos reportar para um universo da fantasia e de um mundo de magia.

Desse modo, Inverter o fluxo desse objeto é também trazer realidade a ele, pensá-lo como de fato ele funcionaria em nosso cotidiano comum: acreditamos que os brinquedos tem o poder de transformar nossa realidade, porém a sua relação de conexão com o real só o tornam cada vez mais impotentes, obsoletos e melancólicos. A realidade sempre se impõe em algum momento. 
A TÍTULO DE CONCLUSÃO/INDICAÇÃO

DE NOVOS PROJETOS

( 


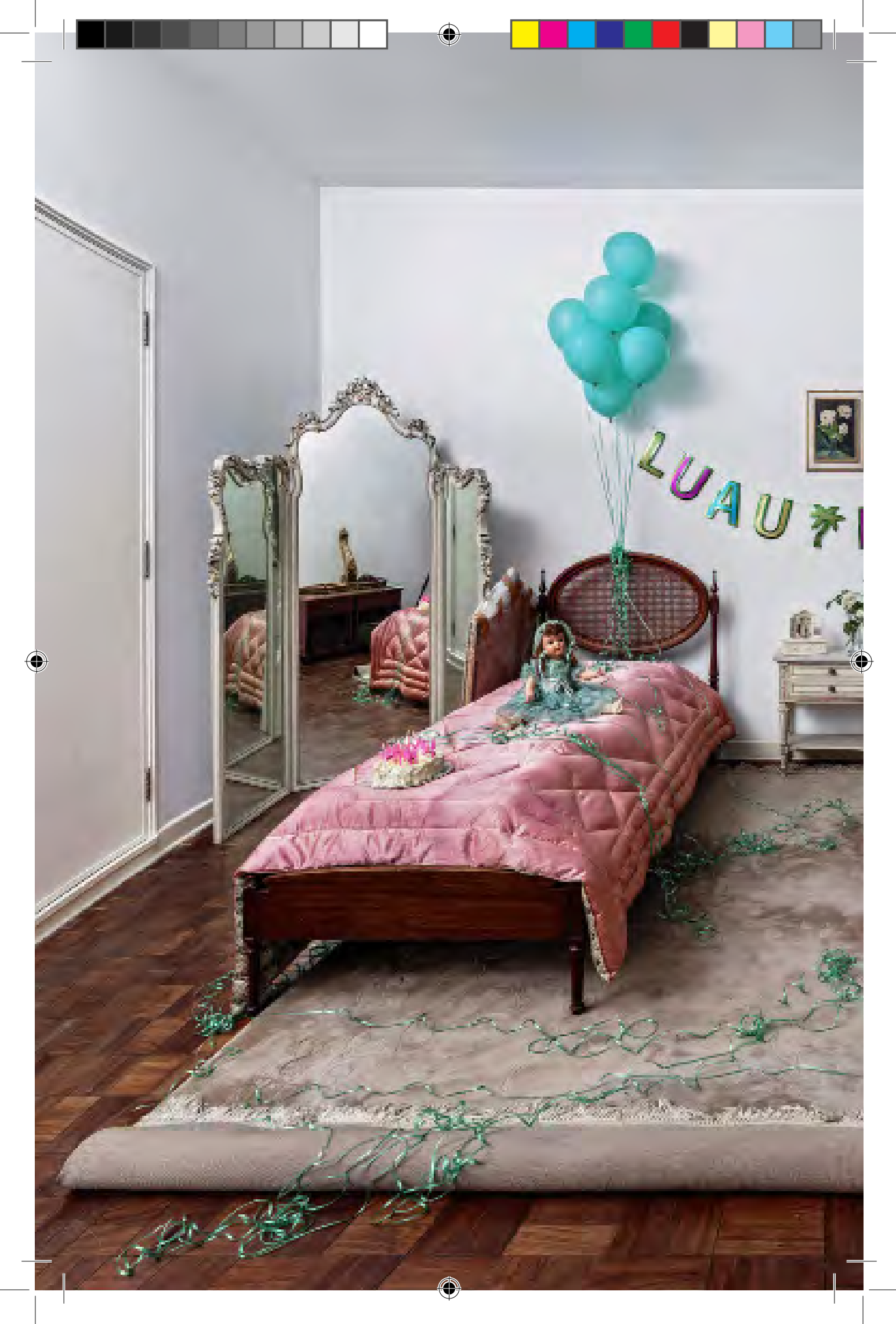




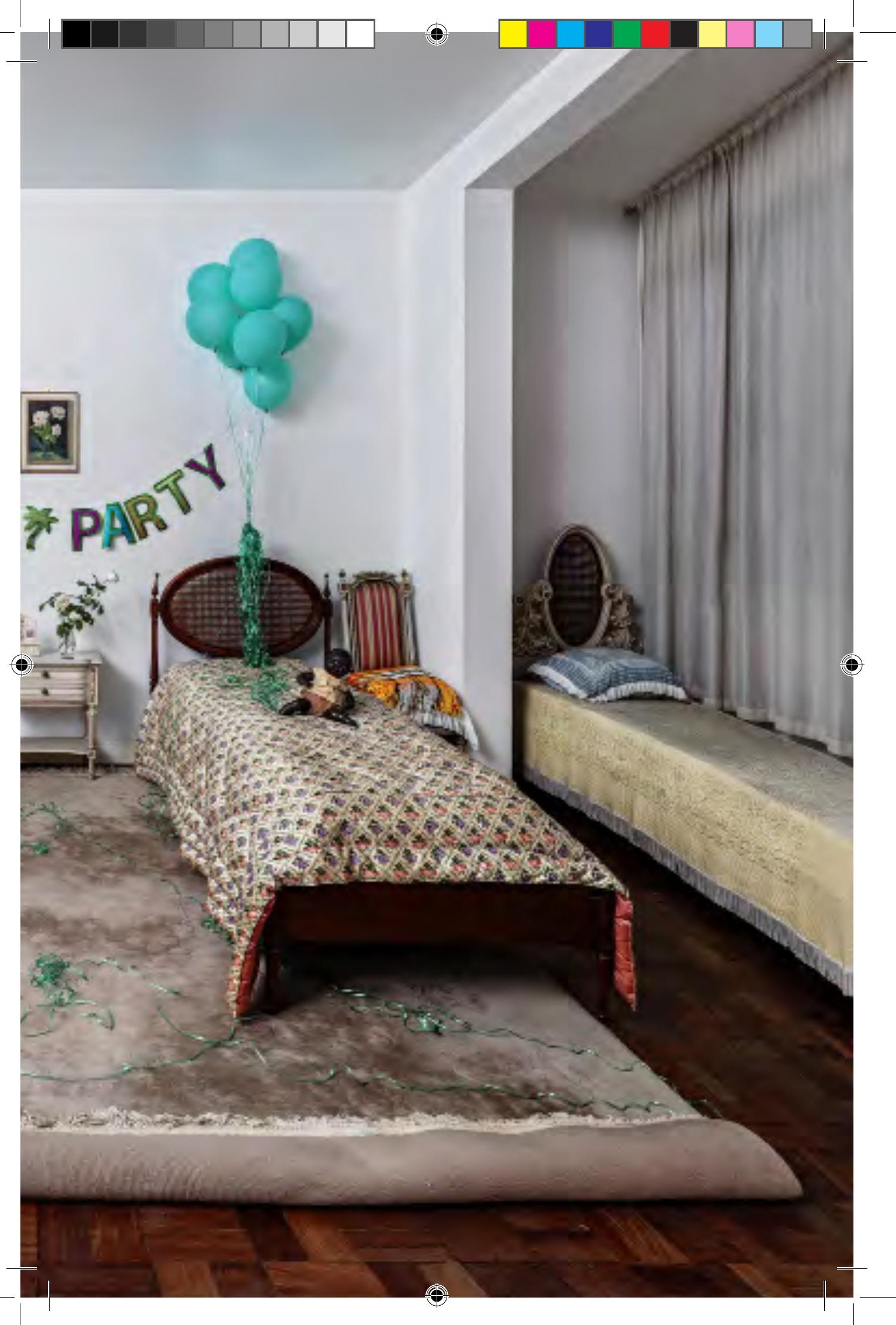




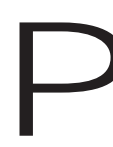

ara encerrar esta dissertação, optei por denominar "A Título de Conclusão" esta passagem, pois acredito que não cabe aqui fazer um fechamento conclusivo sobre os assuntos que foram tratados. Como já disse em outros momentos, 0 que apresentei foram apanhados de projetos que fizeram parte de meu processo como artista durante um longo período de trabalho, estudos realizados como reflexão de alguns assuntos mais recorrentes na pesquisa plástica e as relações de interesse para estudar e continuar a produzir meus projetos futuros. Desse modo, trato o tema da "Teatralidade da vida cotidiana" como um assunto de um projeto que começou e não está encerrado e que talvez nunca se encerre durante meu processo como artista.

Acredito que nos próximos projetos, conseguirei aprimorar e definir até que ponto a realidade pode ser ficcionalizada através de objetos "idealizadores" e até que ponto também não há uma "não separação" entre esses dois universos. Relativizar esta minha "ingenuidade" em separar esses dois universo e tentar entendêlo de modo único pode ser algo importante para novas etapas. Por agora, desejo que os trabalhos que foram apresentados façam sentido dentro de um pequeno grupo de constatações que caracterizaram um tempo de produção que estabeleceram semelhanças e lógicas entre si.

De todo modo é importante já apontar aqui para o surgimento de novos projetos, como por exemplo meu último trabalho, ainda em processo de descoberta, chamado "O Pai, 2014", onde em uma série de ampliações fotográficas em escala real, eu me fotógrafo com meu pai em cenas em que ele aparece me vestindo, ele está vestido de terno e eu com roupa de uma menina colegial.

Algumas mudanças que consigo notar no trabalho são que inicialmente eu performatizava com os objetos de minha casa e após isso sai das imagens e passei apenas a indicar a performance do objeto sozinho no espaço encontrado. Agora neste terceiro momento, volto a aparecer na imagem, evidenciando a minha relação performática com o outro, mas sem os objetos. 


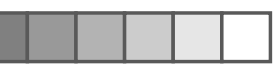

Como se pode notar, há também uma limpeza na imagem que antes era exaustiva por diferentes informações. Desta vez, retiro o cenário, a casa, e os objetos e apenas apresento uma impressão de frieza: não aparecem mais onde a coisa acontece e sim o que acontece. A Teatralidade porém continua como parte da encenação entre eu e o outro e a relação entre o eu e o outro, parece evidenciar um novo tipo de vínculo, que me distancia como artista da relação com os objetos e me aproxima da relação com as pessoas.

Outra questão também importante é pensar que nos novos projetos, trato a figura da infância com menos doçura e ingenuidade, como se eu destituísse do objeto da infância o poder de "amenizar" a dor da realidade. Ao contrário, a coloco como parte da realidade, sugerindo uma malícia entre as relações da criança com certa perversidade.

Talvez agora, o universo adulto possa parecer menos assustador e o universo infantil um pouco menos encantado, mas de certo modo, isso já é algo que sempre esteve presente em todos os trabalhos, afinal as pequenas ruínas que eram apontadas na imagens de conflito entre realidade e ficção já mostravam uma certa ineficiência da infância diante de seu embate para camuflar o real. Resta agora procurar novos caminhos estéticos e reflexivos para continuar trabalhar novas questões e mudanças. 


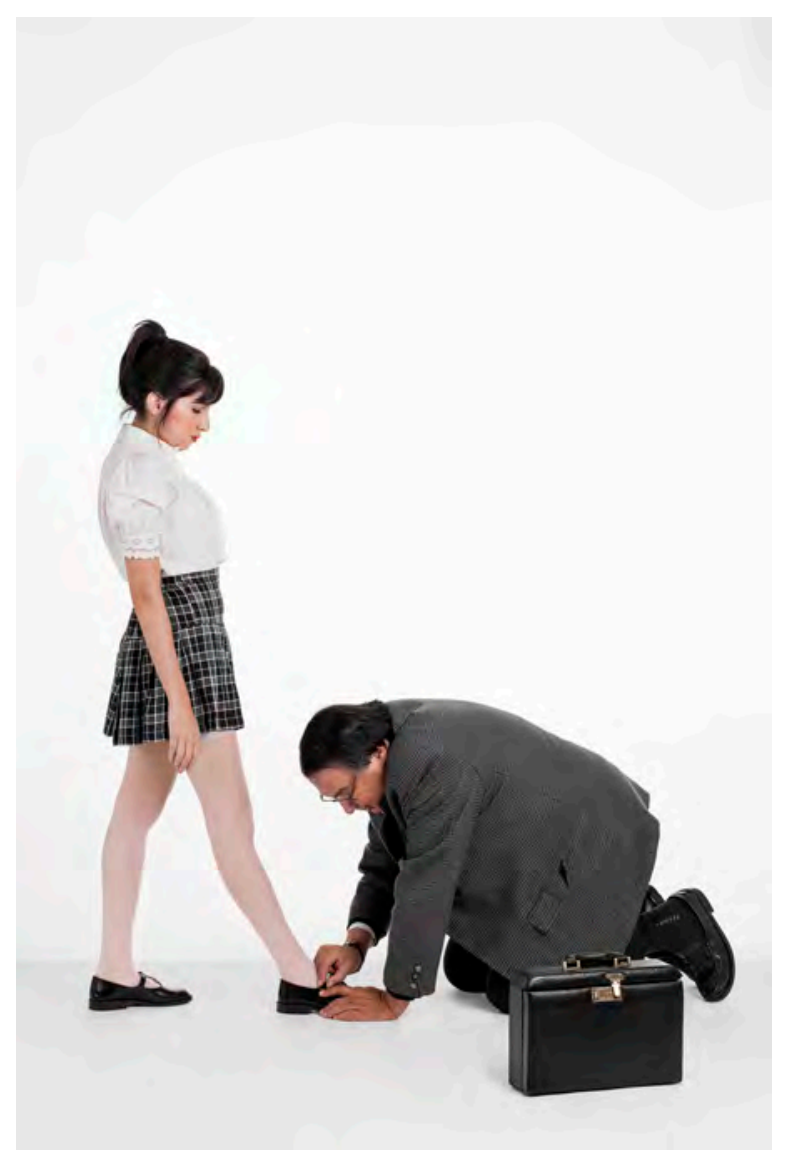

Detalhes das imagens do trabalho "O Pai, 2014". 
ANEXOS

$\oplus$ 


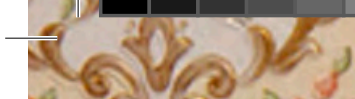

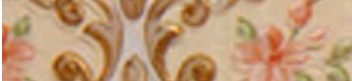

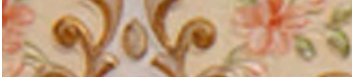

(2) $(2)=$

(4)

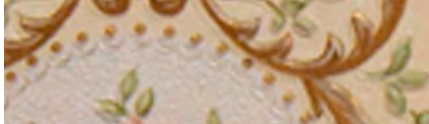

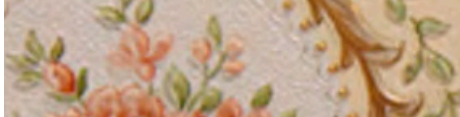

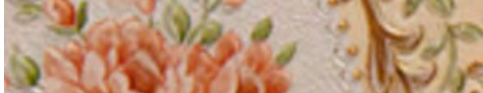

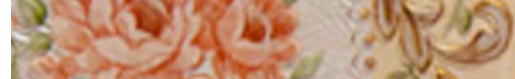

asconger

3.9. v)

*) $x^{2}$

- Co

-) 210

*) a

*) $\mathrm{de} 2$ (

*) 0.18

*) (ब) $2 \%$

c) 0052

*) efक्ष

-)

-)

2) 3018

o) 210

9) $3 y<10$

\%) 10

-) $x$

$2+\frac{1}{2}$

Nin: 10

. $\mathrm{B} / 8$

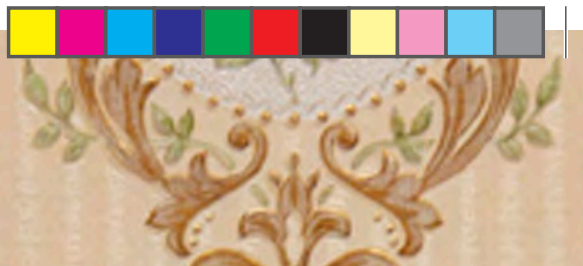

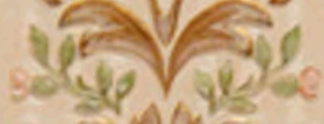

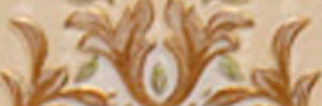

$\sqrt{2}, \ldots, 0$

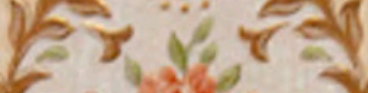

a)

ye ofera ese or

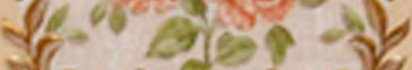

स(, 2$)$ : $(2,1)$

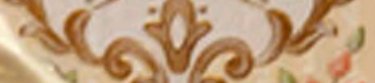

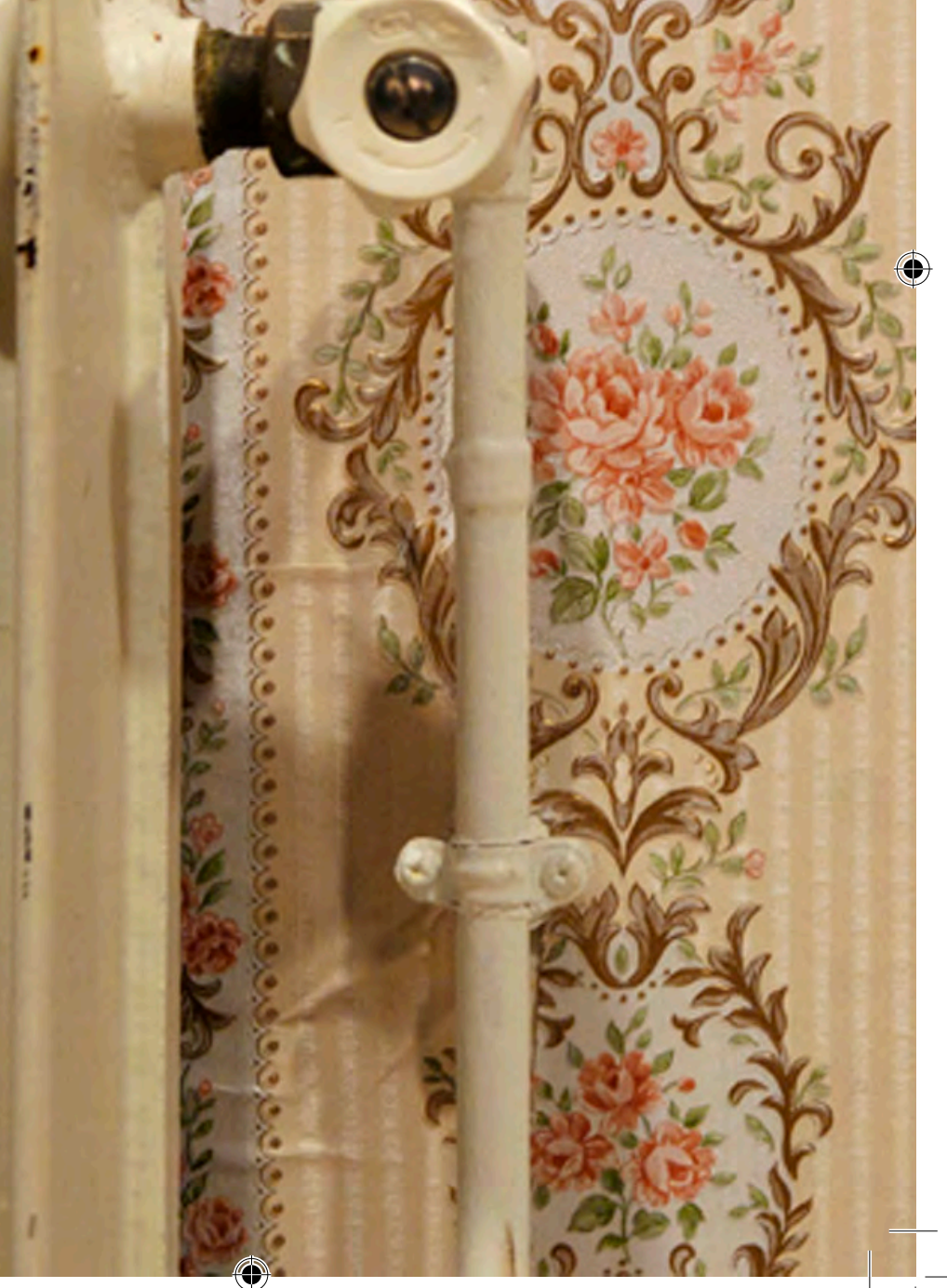

(1) 


\subsection{Texto “Estudo para Diversão" de Ronaldo Entler.}

\section{ESTUdO PARA DIVERSÃO}

"aquilo que tem na infância a sua pátria originária, rumo à infância e através da infância, deve manter-se em viagem." (Giorgio Agamben, Infância e História)

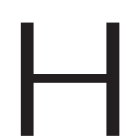
á um paradoxo na apropriação de elementos que repre sentam a infância, porque sempre há nela algo de irre presentável. Como sugere a origem do termo, infantia é a incapacidade de falar, infante é aquele que ainda não tem domínio da linguagem.

Trata-se do estágio da existência em que tudo existe como virtualidade e, assim, em que todas as potências desse sujeito em formação parecem realizáveis. O tempo é aqui a condição para que essas potências se cumpram, mas é também o percurso ao longo do qual parte delas é abandonada.

Para recompor a promessa de plenitude da infância, recorremos a imagens que lhe são muito próprias: 0 passeio em família, o parque, o brinquedo. Mas só conseguimos reencontrar tal momento de uma forma modelar, emblemática, abstrata, distante daquilo que desejamos reviver como experiência efetiva. $\mathrm{O}$ que resta é percorrer artificiosamente as variações desse modelo, como estudo, tipologia ou cartografia, estratégias que abordam com uma razão sistemática aquilo que gostaríamos de resgatar como vivência, como afeto.

Nas fotografias de família em que vemos o passeio ou 0 momento que 0 antecede, espera-se preservar esse instante em que todos os desejos pareciam prestes a ser realizados. Olhando agora 
para esses rostos e gestos, é inevitável intuir certa desconfiança, indícios de que aquela promessa jamais se cumpriria totalmente. As imagens a que recorremos para dar forma a uma fantasia de felicidade são agora signo de uma ausência, tornam-se fantasmas, algo que desejamos tanto quanto nos assombra, porque não reconhecemos mais totalmente como parte do nosso mundo.

A decoração dos parques de diversão, com sua estética arcaica, traz a ilusão de permanência, de uma imobilidade do tempo. Também o cavalo, que está paradoxalmente em movimento e congelado em sua pose, aparece como numa cronofotografia do galope de Muybridge, imagens que almejam resgatar pela técnica aquilo que o fluxo do tempo não permite reter. No final das contas, essa estética arcaica opera como um simulacro que apenas esconde aquilo que a própria diversão consome. Diz Agamben: "em meio aos passatempos contínuos e divertimentos vários, as horas, os dias, as semanas passam num lampejo". Quando se constata que o tempo passou rápido demais, que nele algo foi perdido, e que a própria diversão foi o agenciador dessa passagem, é também pelo recurso a seus mecanismos, agora operando de forma invertida, que se tentará - em vão - retroceder no tempo.

O que a infância demarca é o processo de aquisição da linguagem, ou seja, a capacidade de fazer com que uma forma seja articulada simbolicamente. Também aqui, uma conquista e uma perda: ao querer se apropriar do mundo exercendo a capacidade de representá-lo, o sujeito se vê condenado a uma relação sempre "mediada" com as coisas, que o impede de tocá-las diretamente.

Reconhecemos algumas estratégias de compensação: a cartografia contém a promessa de que a representação (o mapa) irá garantir o acesso ao espaço real (o território). Mas aquilo que é cartografado já é em si uma representação, um brinquedo, uma forma simbólica constituída pela linguagem. Nesse caso, trazer para a cena o brinquedo em sua escala real ("real" é aqui força de expressão) seria talvez um esforço para compensar o fracasso do mapa fazendo-o coincidir com o território, como fizeram os cartógrafos 
do império imaginado por Borges ("Del rigor en la ciencia"). Inevitável reconhecer que esse empenho aponta apenas para uma utopia: uma mapa inoperante feito para um território inalcançável.

"Dar sentido" às coisas é colocá-las num certo fluxo, mas é também dar a elas uma significação. É, simultaneamente, a experiência do tempo e da linguagem. "Inverter o sentido" sugere o desejo de retornar ao ponto de partida, a uma origem, ao grau zero da significação, ao tempo em que todas as potências pareciam realizáveis. Mas resulta no absurdo, na música desarmoniosa, no movimento disfuncional do brinquedo; em outras palavras, na consciência de que a memória jamais reencontrará o passado de forma intacta.

Resta certa melancolia. Mas a resposta que vemos não é de todo niilista, porque não resulta em inércia, na mera constatação de um fracasso. A arte é o campo em que a própria linguagem revela sua maior vitalidade, em que é possível jogar de modo mais intenso e livre com suas próprias potências. Pela arte, não se busca apenas o relato desses momentos irrecuperáveis, escava-se a memória também na direção de um porvir. Isso é possível porque a origem não é um espaço morto, um paraíso perdido. É ainda a fonte de tensões que alimentam uma busca. Como reivindicado por Agamben, "uma tal origem não poderá jamais resolver-se completamente em 'fatos' que se possam supor historicamente acontecidos, mas é algo que ainda não cessou de acontecer". Na mesma medida em que o tempo evidencia aquilo que parece irrecuperável, ele abre diante de nós o território em que todas as coisas ainda estão por ser construídas.

Não se trata de arrancar pela diversão um riso pleno, como aquele que acreditamos ter existido na infância. A diversão diz respeito agora àquilo que pode haver de diverso, divergente, à possibilidade de produzir perturbações no curso de um tempo que muitas vezes nos parece retilíneo e homogêneo.

\section{Ronaldo Entler}




\subsection{ENTREVISTA:}

Programa de Exposições do PaÇo das Artes 2013.

I. Durante o período de formação na FAAP você trabalhou com cenografia. Como você acha que essa experiência contribuiu ou influenciou sua produção naquela época? Pergunto isso pensando principalmente das obras $\mathrm{Na}$ companhia dos objetos (2008-2009) e A casa em festa (2009-2010).

Quando realizei a série "Na Companhia dos Objetos", percebi que o meu procedimento com as fotografias "encenadas", era também uma organização que me remetia a práticas elaboradas durante o raciocínio de ateliê para a cena teatral.

Naquele momento, o meu interesse era mais focado na parte teórica do que prática. Por muito tempo me dediquei a escrever sobre pesquisas de arquitetura teatral e teoria da cenografia.

Acredito que a contribuição tenha vindo dessa dedicação diária que me fez entender intuitivamente a construção de cena e a organização da escolha de objetos utilizados em virtude do enquadramento da câmera fotográfica.

Se hoje você me pede para montar uma cenografia que de fato será utilizada como estrutura "habitável", é bem provável que nada pare de pé, pois o que faço é lidar com as situações abstratas e entendelas como uma composição que funciona no limite da foto.

II. Em seu ateliê, você comentou bastante a respeito da teatralidade, principalmente no que diz respeito aos diferentes papéis que o ser humano desempenha em seu cotidiano. Não pude deixar de pensar num conto do Machado de Assis, O Espelho, no qual ele diz que cada ser humano possui duas almas - uma que olha de dentro para fora, outra que olha de fora para dentro. Obviamente suas referências vão para além do campo 
das artes. Por favor, fale um pouco sobre elas.

Atualmente tenho pensado sobre o tema da teatralidade inserida na vida cotidiana das pessoas. Recentemente cursando o mestrado, optei por escolher disciplinas que falassem diretamente sobre algumas palavras chaves que estão inclusas na pesquisa.

Para citar alguns assuntos, creio que a análise do teatro e da teatralidade como estrutura cênica específica, em que a principal função torna-se representar diferentes papéis, é bastante importante nesse momento. A arquitetura como o lugar do acontecimento da representação, seja ela representação teatral ou representação real e a sociologia que estuda a representação como também ação coletiva de "sobrevivência", são outros exemplos de pontos que interessam nesse momento.

Para além de uma teoria, minhas grandes referencias também estão no próprio cotidiano: a observação dos objetos que chamo de "ficcionais", minhas memória de infância, filmes que procuro assistir que remarcam alguns dos temas abordados, além de minhas relações pessoais diárias, que idealizam e desmistificam a realidade a cada pequena experiência.

III. Você se formou há pouco tempo no curso de Artes na FAAP e já realizou duas residências fora do país, uma em Paris, na Cité Internationale Dês Arts, e outra na Ucrânia, na cidade de Donestk. Sendo lugares tão díspares e diferentes de São Paulo, queria saber como foram essas experiências e vivências para a sua pesquisa?

Acredito que até agora essas tenham sido as experiências mais importantes. Não somente pelo fato de serem lugares distintos, a pensar Paris com suas paisagens de cartões postais ou D onetsk com sua estética exótica.

Digo isso porque em 2010, tive a oportunidade de participar de algumas experiências em São Paulo, que me fizeram enxergar o quanto o excesso de demanda comercial atrelado a falta de experiência, haviam tornado bastante frágeis as maneiras como eu 
lidava com o meu trabalho. A saída para Paris foi providencial na medida em que rompeu com alguns vínculos: saí da galeria que me representava e não tinha a mesma facilidade dos costumes e entornos. Tudo isso me obrigou a repensar onde eu deveria centralizar meu trabalho e lidar com um tempo longo dedicado a produção sem retornos imediatos, o que trouxe leveza para pensar o trabalho, processo e mais complexidade.

IV. Em Projeto para Finais Felizes (2013), obra apresentada na Temporada de Projetos no Paço das Artes, você parte de uma profusão de finais felizes tirados de contos de fadas. De fato esse projeto espelha uma relação com a vida contemporânea, em que todos almejam incessantemente a felicidade.

No entanto, sua produção parece alertar para lampejos de angústia, que se manifestam por sutilezas, por vezes irônicas, como nas bexigas murchas, num olhar apático na festa, ou em cenas bizarras ilustradas em contos de fadas. Para você, em breves palavras, o que há de errado com a felicidade?

Na obra que apresento no Paço, procuro coletar finais felizes de livros infantis e estabeleço o objetivo de apagar toda a história e deixar somente o motivo pelo qual o personagem encontrou sua felicidade. De fato, procurar me aproximar de uma ligação real e cotidiano que é também uma busca diária e infinita pela felicidade, me possibilita tentar através de uma investigação de arquivos, descobrir quais são os parâmetros que caminham entre uma vida que sempre espera da realidade uma somatória de resultados que surgem como promessa no campo da ficção.

Os acúmulos que repetem a mesma intenção ilusória de tudo acabar bem, são contraditórios na sua própria existência, pois parecem elencar motivos concretos e morais que nos alertam para a auto realização e ao mesmo tempo se tornam patéticos quando se anulam numa repetição muda e em excesso. 
Na minha opinião, não há nada de erro na idéia de felicidade, se não em sua forte relação de desejo em avançar a frente do que é próprio da realidade. $O$ que faço através do trabalho é tentar estabelecer uma relação de observação entre essas duas estruturas, uma voltada para a estética de idealização ficcional de teatralidade da vida cotidiana e outra que escancara seus ruídos e suas incompletudes. No fim esses dois espaços estão completamente juntos, um potencializando e enfraquecendo o sucesso e o insucesso do outro. 


\section{REFERÊNCIAS BIBLIOGRÁFICAS}

BACHELARD, Gastón. A Poética do Espaço. 2. ed. São Paulo: Martins Fontes, 2008.

BORGES, Jorge Luiz. "Esse ofício do Verso". 1ed. São Paulo: Cia das Letras, 2000.

BOSI, Ecléa. O tempo vivo da memória: ensaio de psicologia social. São Paulo: Ateliê Editorial, 2003.

CARRIERE. Jean Claude. Fragilidade. Trad. Rejane Janowitzer. Rio de Janeiro: Objetiva, 2007.

COTTON, Charlotte. A fotografia como arte contemporânea. Trad. Maria Silvia Mourão Netto. São Paulo: Editora WMF Martins Fontes, 2010.

ENTLER, Ronaldo. Memórias fixadas, sentidos itinerantes: os arquivos abertos de Chris Marker. Facom - Revista da Faculdade de Comunicação e Marketing - FAAP, n. 19, 1.ํㅗㅇ sem. de 2008, p. 04-15.

FABRIS, Annateresa. Identidades Virtuais - uma Leitura do Retrato Fotográfico. Belo Horizonte: Editora UFMG, 2004.

FERAL, Josette. A cerca de la teatralidad. Caderno de Teatro XXI. Buenos Aires: Nueva Geracion, 2003.

FOAM Magazine. A book of beds. Amsterdã: Foam, 2011.

FRANKFUREDI. Não quero ser grande. Folha de São Paulo, São Paulo, 25 Julho. 2004. Mais!Folha de São Paulo, p. 4 - 7.

GOFFMAN, Erving. A representação do eu na vida cotidiana. Trad. Maria Célia Santos Raposo. 17. ed. Petrópolis: Vozes, 2009. KOSSOY, Boris. Realidades e Ficções na Trama Fotográfica. São Paulo: Ateliê Editorial, 2002.

JUNIOR, Rubens Fernandes. Processos de criação na fotografia: apontamentos para o entendimento dos vetores e das variáveis da 
produção fotográfica. - Revista da Faculdade de Comunicação e Marketing - FAAP - n16 - 2 sem. de 2006, p. 10 - 19.

NOVAES. Sylvia Caiuby. Imagem, mágia e imaginação: desafios ao texto antropológico. Mana [online]. 2008, vol.14, n.2, pp. 455-475. PARDO, Ana Lúcia. A Teatralidade do Humano. São Paulo: Edições Sesc SP, 2011.

PATRICE, Pavis. Dicionário de Teatro. 3. ed. São Paulo: Perspectiva, 2008.

SARRAZAC, Jean Pierre. A invenção da Teatralidade. São Paulo: Deriva, 2009.

WINNICOTT, Donald W. L'enfant et sa famille. Trad. Annette Stronck-Robert. Paris: Payot \& Rivages, 2002.

WOOLF, Virginia. Mrs. Dolloway. Trad. Claudio Alves Marcondes. São Paulo: Cosac Naify, 2012.

\section{REFERÊNCIAS BIBLIOGRÁFICAS ONLINE/CATÁLOGOS/FILMES:}

ENTRE REALIDADE E FICÇÃO. Estação Pinacoteca de São Paulo. São Paulo, 2006.

BIG. DVD Fox Film Corporation, 1988.

http:/ /virgulauol.com.br/ ver/ noticia/ inacreditavel/2012/ 02/ 06/ 293745fa miliarnganizafuneral-oom-personagens-dadisney-parabebe\#2 
